\title{
Evaluation of Exposure to Metals and Flame Retardants at an Electronics Recycling
}

\section{Company}

\section{George R. Grimes, MD, MPH}

Catherine C. Beaucham, MPH, CIH, RS/REHS

Michael P. Grant, ScD

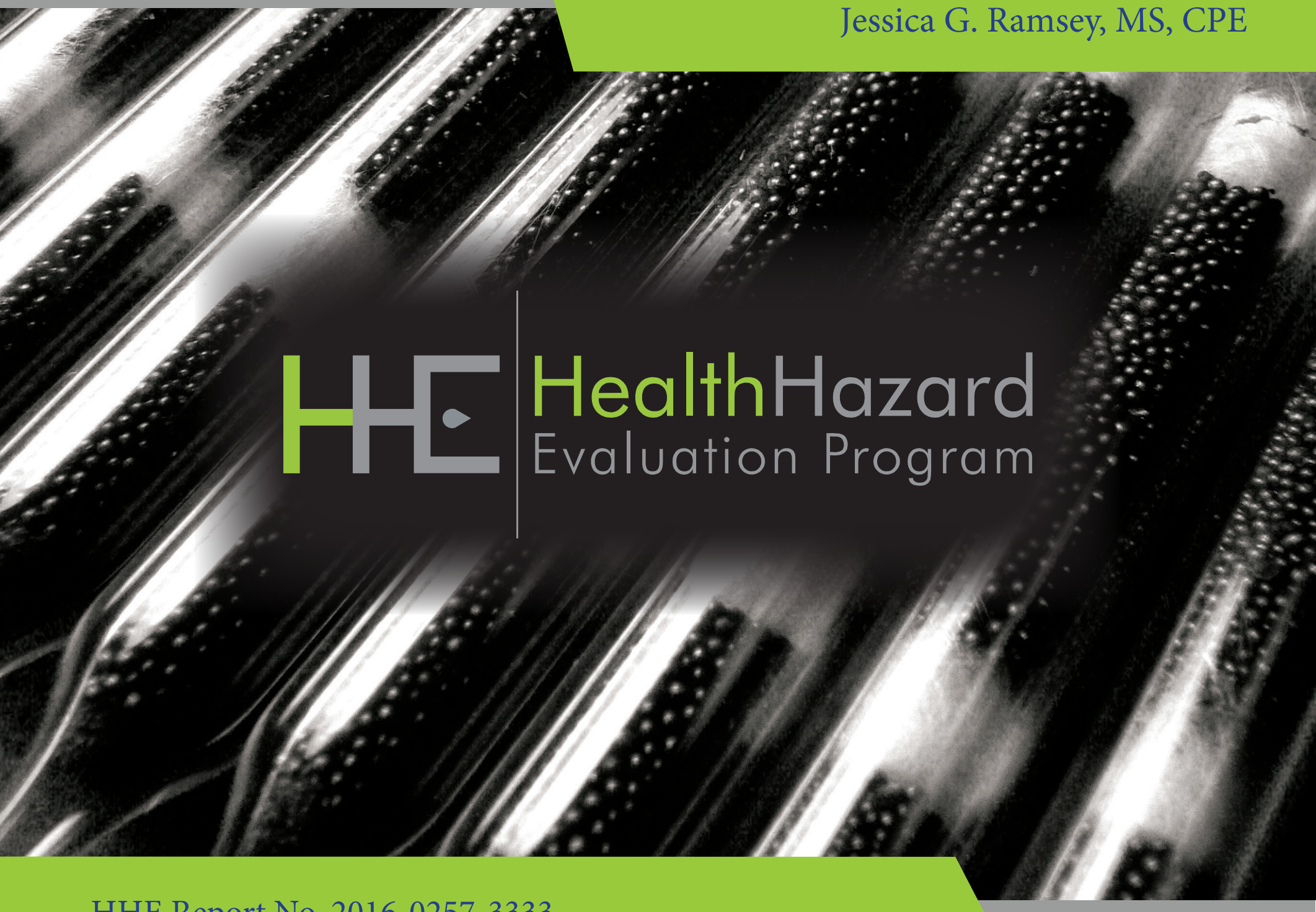

HHE Report No. 2016-0257-3333

March 2019

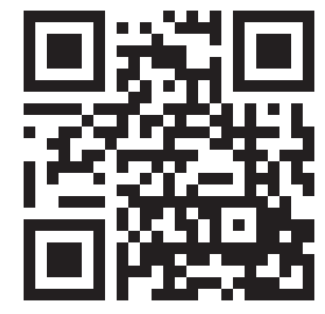

Centers for Disease Control

and Prevention

National Institute for Occupational

Safety and Health 


\section{Contents}

Highlights.

Abbreviations ...................................... iii

Introduction ............................................ 1

Methods ............................................... 3

Results ............................................... 8

Discussion ............................................. 30

Conclusions ...................................... 41

Recommendations.......................... 42

Appendix A ...................................... 45

Appendix B .......................................... 51

References........................................... 62

Acknowledgements......................... 73

The employer is required to post a copy of this report for 30 days at or near the workplace(s) of affected employees. The employer must take steps to ensure that the posted report is not altered, defaced, or covered by other material.

The cover photo is a close-up image of sorbent tubes, which are used by the HHE Program to measure airborne exposures. This photo is an artistic representation that may not be related to this Health Hazard Evaluation. Photo by NIOSH. 


\section{Highlights of this Evaluation}

The Health Hazard Evaluation Program received a request from an electronics recycling company. The managers were concerned about exposure to metals and flame retardants, as well as ergonomic stressors and hazardous levels of noise.

\section{What We Did}

- We evaluated the electronics recycler in November 2016 and February 2017.

- We collected surface, hand wipe, and air samples for 32 elements and 22 flame retardants.

- We collected blood samples for cadmium, indium, lead, and 8 flame retardants.

- We collected urine samples for 7 flame retardants.

- We measured peak sound pressure levels at some equipment.

- We observed employees and assessed possible ergonomic hazards.

\section{What We Found}

- We found that the levels of some flame retardants on employees' hands were higher after work than before.

- We found some of the 22 flame retardants in the air.

- None of the personal air samples for metals were above exposure limits.

- We found some of the flame retardants and metals in the employees' blood or urine.

- We found lead and cadmium in the employees' blood. None of the blood samples were above reference levels.

- We observed employees wearing ear plugs and N95 respirators incorrectly.

- We found the workstations were set at fixed heights and therefore could not be easily adjusted to fit the height of each employee who rotated to the workstation.

- We observed that anti-fatigue mats were available but not used by most employees during disassembly tasks.

- We observed poor lighting at workstations because the overhead task lights were turned off.

- We observed employees dry sweeping. 


\section{What the Employer Can Do}

- Include all processing employees in a lead exposure prevention program.

- Provide employees with a lead-removing product to wash their hands. Soap and water is not enough.

- Re-train employees on the proper wear and use of respirators and ear plugs, even if worn voluntarily.

- Replace worn out anti-fatigue mats.

- Provide easily adjustable workstations that employees can adjust for their comfort.

\section{What Employees Can Do}

- Wash your hands with a lead-removing product before eating, drinking, smoking, or leaving work.

- Do not dry sweep. Use wet cleaning methods or high-efficiency particulate air vacuuming instead. Use a magnetic sweeper to remove metal scraps or loose screws from the work area.

- Wear ear plugs and N95 respirators correctly.

- Use anti-fatigue mats and overhead workstation lights. 


\section{Abbreviations}

\begin{tabular}{|c|c|}
\hline$\alpha-\mathrm{HBCD}$ & $\alpha$-hexabromocyclododecane \\
\hline$\beta-\mathrm{HBCD}$ & $\beta$-hexabromocyclododecane \\
\hline$\gamma$-HBCD & $\gamma$-hexabromocyclododecane \\
\hline$\mu \mathrm{g}$ & Microgram \\
\hline$\mu \mathrm{g} / 100 \mathrm{~cm}^{2}$ & Micrograms per 100 square centimeters \\
\hline$\mu \mathrm{g} / \mathrm{g}$ & Micrograms per gram \\
\hline$\mu \mathrm{g} / \mathrm{m}^{3}$ & Micrograms per cubic meter \\
\hline$\mu \mathrm{g} / \mathrm{dL}$ & Micrograms per deciliter \\
\hline$\mu \mathrm{g} / \mathrm{L}$ & Micrograms per liter \\
\hline$\mu \mathrm{m}$ & Micrometer \\
\hline ACGIH® & American Conference of Governmental Industrial Hygienists \\
\hline ACOEM & American College of Occupational and Environmental Medicine \\
\hline BCEP & bis(2-chloroethyl) phosphate \\
\hline BCIPP & bis(1-chloro-2-propyl) phosphate \\
\hline BDCIPP & bis(1,3-dichloro-2-propyl) phosphate \\
\hline BDE-17 & 2,2',4'-tribromodiphenyl ether \\
\hline BDE-28 & 2,4,4'-tribromodiphenyl ether \\
\hline BDE-47 & 2,2',4,4'-tetrabromodiphenyl ether \\
\hline BDE-85 & 2,2',3,4,4'-pentabromodiphenyl ether \\
\hline BDE-99 & 2,2',4,4',5-pentabromodiphenyl ether \\
\hline BDE-100 & 2,2',4,4',6-pentabromodiphenyl ether \\
\hline BDE-153 & $2,2^{\prime}, 4,4^{\prime}, 5,5^{\prime}$-hexabromodiphenyl ether \\
\hline BDE-154 & 2,2',4,4',5,6'-hexabromodiphenyl ether \\
\hline BDE-183 & 2,2',3,4,4',5',6-heptabromodiphenyl ether \\
\hline BDE-206 & $2,2^{\prime}, 3,3^{\prime}, 4,4^{\prime}, 5,5^{\prime}, 6$-nonabromodiphenyl ether \\
\hline BDE-209 & decabromodiphenyl ether \\
\hline BEH-TEBP & Bis(2-ethylhexyl) tetrabromophthalate \\
\hline BLL & Blood lead level \\
\hline BTBPE & 1,2-Bis(2,4,6-tribromophenoxy)ethane \\
\hline $\mathrm{CDPH}$ & California Department of Public Health \\
\hline CFR & Code of Federal Regulations \\
\hline CSTE & Council of State and Territorial Epidemiologists \\
\hline DecaBDE & Decabromodiphenyl ether technical mixture \\
\hline $\mathrm{dB}$ & Decibel \\
\hline DBDPE & Decabromodiphenyl ethane \\
\hline $\mathrm{DoCP}$ & di-o-cresylphosphate \\
\hline $\mathrm{DpCP}$ & di-pcresylphosphate \\
\hline DPHP & diphenyl phosphate \\
\hline EH-TBB & 2-ethylhexyl 2,3,4,5-tetrabromobenzoate \\
\hline GM & Geometric mean \\
\hline LCD & Liquid crystal diode \\
\hline LOD & Limit of detection \\
\hline
\end{tabular}




\begin{tabular}{|c|c|}
\hline $\mathrm{mL}$ & Milliliter \\
\hline $\mathrm{mg} / \mathrm{dL}$ & Milligram per deciliter \\
\hline $\mathrm{ng} / 100 \mathrm{~cm}^{2}$ & Nanograms per 100 square centimeters \\
\hline $\mathrm{ng} / \mathrm{g}$ & Nanograms per gram \\
\hline $\mathrm{ng} / \mathrm{m}^{3}$ & Nanograms per cubic meter \\
\hline ng/sample & Nanograms per sample \\
\hline $\mathrm{NCEH}$ & National Center for Environmental Health \\
\hline ND & Not detected \\
\hline NHANES & National Health and Nutrition Examination Survey \\
\hline NIOSH & National Institute for Occupational Safety and Health \\
\hline OctaBDE & Octabromodiphenyl ether technical mixure \\
\hline OEL & Occupational exposure limit \\
\hline OSHA & Occupational Safety and Health Administration \\
\hline PBDE & Polybrominated diphenyl ethers \\
\hline PCB & Polychlorinated biphenyls \\
\hline PEL & Permissible exposure limit \\
\hline PentaBDE & Pentabromodiphenyl ether technical mixture \\
\hline $\mathrm{PP}$ & Persistent pesticides \\
\hline PPE & Personal protective equipment \\
\hline REL & Recommended exposure limit \\
\hline STEL & Short-term exposure limit \\
\hline TBBA & 2,3,4,5-tetrabromobenzoic acid \\
\hline TBBPA & tetrabromobisphenol A \\
\hline TCP & Tricresyl phosphate \\
\hline TCEP & Tris(chloroethyl) phosphate \\
\hline TCIPP & Tris(2-chloroisopropyl) phosphate \\
\hline TDCIPP & Tris(1,3-dichloro-2-propyl) phosphate \\
\hline TPHP & Tris(phenyl) phosphate \\
\hline TLV® & Threshold limit value \\
\hline TWA & Time-weighted average \\
\hline
\end{tabular}




\section{Introduction}

The Health Hazard Evaluation Program received a request from an electronics recycling company. The employer was concerned about possible employee exposures to flame retardant chemicals (flame retardants) and metals, ergonomic stressors, and hazardous levels of noise while recycling electronics. We first visited the facility in November 2016. We met with employer and employee representatives and toured the workplace to observe operations, work practices, and working conditions. We returned in February 2017 to collect air, hand wipe, blood, and urine samples for metals and flame retardants, took sound level measurements, and assessed possible ergonomic hazards. We provided preliminary observations and recommendations to the employer and the employee representatives in November 2016 and March 2017.

\section{Background}

Electronic devices contain heavy metals and many chemical substances including chemical flame retardants. Specifically, flame retardants are found in plastic and resin housings and components, wires, cable insulation, and circuit boards. They are also added to manufactured materials, surface finishes, and coatings to inhibit, suppress, or delay combustion and impede the spread of fire. Many electronics also contain dusts from sources such as carpet padding or office furniture foam that may contain flame retardants.

Polybrominated diphenyl ethers (PBDEs), tetrabromobisphenol A (TBBPA), and organophosphates are examples of flame retardants used in electronics. Recent observational epidemiological research concluded that PBDEs are associated with liver, thyroid, reproductive/developmental, and neurological effects [Dallaire et al. 2009; Grant et al. 2013]. Although PBDEs are no longer used in the manufacture of U.S. electronics, they will remain in the electronic recycling stream for decades. TBBPA, tris(phenyl) phosphate (TPHP), and other brominated flame retardants and organophosphate flame retardants will continue to be used and be present in the electronics recycling stream. Organophosphate flame retardants have been associated with adverse reproductive/developmental and neurological effects in animals [van der Veen and de Boer 2012]. We are able to measure levels of some flame retardants in blood and urine, but there is scientific uncertainty regarding the relationship between these levels in the body and specific health outcomes. More detailed information about flame retardants can be found in Appendix B.

Previous NIOSH health hazard evaluations [NIOSH 2009, 2014a, 2018a,b] found employee exposures to metals and flame retardants during electronic recycling, such as:

- lead from batteries, printed circuit boards, power cords, and cathode ray tubes;

- cadmium from batteries, pigments, plastic stabilizers, metal coatings, and cathode ray tubes phosphors; and mercury from fluorescent lights, batteries, medical and telecommunication equipment, and some flat-panel displays; and

- flame retardants in computer and monitor housings, printed circuit boards, cables, conveyor belts, wire and cable insulation, and polyurethane foam. 
Electronic recycling employees may also be exposed to indium, a metal used in flat-panel displays and touchscreens. Employee overexposures and potential take-home exposures to metals in the electronics recycling industry have also been documented [Ceballos et al. 2016; Ceballos and Dong 2016; Newman et al. 2015; NIOSH 2009, 2014a]. More detailed information about lead and other metals can be found in Appendix B.

\section{Process Description}

The company began operations in a 25,000 square foot warehouse in 2005, with an additional 9,000 square foot addition added in 2007. At the time of our evaluation, approximately 50 employees worked at the company. Their primary activities included sorting and taking inventory of incoming electronics, refurbishing and resale of functional electronics, manual and mechanical disassembly of electronics, and office work.

\section{Sorting and Inventory}

Approximately six employees evaluated, catalogued, and sorted electronics at inventory stations upon entry to the facility on the basis of whether the electronics were considered "endof-life" or could be re-used. Electronics considered to be end-of-life were sent through the disassembly process. Reusable electronics were sent to the refurbishing and resale departments.

\section{Refurbishing}

Ten employees worked in the refurbishing stations. They used an industrial shop vacuum cleaner to remove dust from the electronic equipment. In the pre-test area, employees tested the functionality of batteries, laptops, and other electronic equipment. If the central processing unit of the computer functioned, it was sent to the "wiping bench" to have all of the data removed and then the software reloaded.

\section{Resale}

Resale employed six employees. They photographed the equipment, listed it on used equipment internet resale sites, and prepared it for shipping.

\section{Disassembly}

The disassembly department had twelve employees. Employees could rotate through all of the positions during the day, especially the triage and floating positions. Triage employees sorted the end-of-life electronics and delivered them to the appropriate disassembly workstation. The floating employees replaced employees at the disassembly stations when needed, removed buckets and/or boxes that had been filled from the workstations, and delivered the required tools and personal protective equipment (PPE) to the workstations, as needed. The liquid crystal diode (LCD) panel employees disassembled LCD screens and removed mercury containing bulbs over the downdraft table. Air from the downdraft table passed through a combination high efficiency particulate air and carbon filter before being recirculated back into the warehouse. Typically, only one employee sorted lithium-containing and other batteries. This task was done for approximately two hours every day. One dedicated employee operated the shredder for four hours per week to shred end-of-life hard drives. 
Other disassembly tasks included removing the yoke from cathode ray tubes and crushing the plastic housings of the electronic parts. Required PPE for the disassembly department included safety glasses, steel-toed shoes, and Kevlar® or leather gloves. Use of filtering facepiece respirators (N95) was voluntary. In addition to these, the shredder operator wore ear plugs.

\section{Office Employees}

Five to ten employees worked in the office. These employees typically worked at a desk using a computer. Some employees periodically entered the recycling warehouse, while others rarely entered the warehouse.

\section{Methods}

We presented the objectives and elements of our evaluation to all employees assigned to the sorting and inventory, refurbishing, resale, disassembly, and office departments. We told employees that we would only be able to evaluate 19 employees during this evaluation and asked for volunteers. We obtained informed consent from all participants prior to beginning the evaluation. We asked all participants to fill out a questionnaire about their pertinent personal and work history such as length of employment, job tasks, current practices, use of PPE, and hygiene practices. At the end of each day, we asked each participant to complete a brief questionnaire about their work practices on that day. Our objectives were to evaluate metal and flame retardant exposures, as detailed below:

Metals

1. Characterize employee exposures to metals.

2. Assess whether employee exposures to airborne metals exceeded applicable occupational exposure limits (OELs).

3. Assess whether employees' blood lead and cadmium levels exceeded biological exposure indices.

4. Evaluate the potential for take-home contamination from metals.

Flame retardants

1. Characterize employee exposures to selected flame retardants.

2. Compare the levels of selected flame retardants in employees' blood and urine to levels in the general population.

3. Assess whether airborne and dermal exposures to selected flame retardants contributed to the levels in employees' blood and urine.

Appendix A, Table A1 lists the flame retardants that we sampled for, where they are typically found, and when they are typically used, if used in electronics. Appendix A, Table A2 lists the three types of PBDE technical mixtures that we sampled for and their major congeners (a group of related chemicals). PBDE technical mixtures include pentabromodiphenyl ether (PentaBDE), octabromodiphenyl ether (OctaBDE), and decabromodiphenyl ether 
(DecaBDE). For some of our analyses, we divided the flame retardants into five categories on the basis of their usage in electronics.

In addition to the primary objectives, we evaluated ergonomic hazards and measured peak sound pressure levels at some equipment.

\section{Surface and Hand Wipe Samples for Metals}

We collected and analyzed surface and hand wipe samples for metals according to NIOSH Manual of Analytical Method 9102 including indium and lithium [NIOSH 2018c]. For surface samples, we used a 10 centimeter by 10 centimeter square disposable template to demarcate the sampling area and wiped the surface with a premoistened SKC Inc.

Ghostwipe ${ }^{\circledR}$ towelettes. We also collected a postshift hand wipe sample for metals from each participant on one day using the same method as previously described for flame retardants, except that we used the pre-moistened Ghostwipe towelettes instead of alcohol soaked wipes. We collected these hand wipe samples after the employee washed his or her hands to determine the potential for take-home exposure. These samples were not collected on the same day as the hand wipe samples for flame retardants.

\section{Air Samples for Metals}

We collected personal and area air samples for metals and minerals, including indium and lithium, on 37 millimeter $(\mathrm{mm})$ cassettes and analyzed them according to NIOSH Method 7303 [NIOSH 2018c] with modification. The modification included using a digestible Solu-CAP® to collect particles on the inside of the cassette walls as recommended by NIOSH [2016].

\section{Surface and Hand Wipe Samples for Flame Retardants}

In February 2017, we collected preshift and postshift handwipe samples on two sampling days. We pre-soaked two, 3-inch by 3 -inch gauze pads in approximately 6 milliliters $(\mathrm{mL})$ of laboratory grade 99\% isopropyl alcohol and placed them in a glass vial [Carignan et al. 2013]. We put on clean nitrile gloves, then opened the glass vial, and asked the employee to take one wipe and wipe both palms from wrist to finger tips for 30 seconds, then place the wipe back into the same glass vial. We then asked the employee to take the second wipe and repeat the process for the back of both hands and again place the wipe into the same glass vial. We sealed the vial with its lid and a parafilm wrap. We collected the postshift sample before each participating employee washed his or her hands prior to going home.

We collected surface wipe samples for flame retardants in the processing area. We used a 10 centimeter by 10 centimeter square disposable template to demarcate the sampling area and then used the premoistened alcohol wipes to wipe the surfaces. We collected these surface wipe samples to determine which type of flame retardants were present in the work environment, where they were located, and in which areas their levels were the highest.

A contract lab analyzed all hand wipes for flame retardants by ultra-performance liquid chromatography atmospheric pressure photoionization tandem mass spectrometry using methods previously described by La Guardia and Hale [2015]. All wipes were spiked with 
surrogate standards prior to extraction to determine the percent recovery for each type of flame retardant. The wipe sample results were surrogate corrected for percent recovery.

The flame retardants for which we analyzed are listed below. We used the abbreviation standard for flame retardants proposed by Bergman et al. [2012]:

- $\alpha$-hexabromocyclododecane $(\alpha$-HBCD)

- $\beta$-hexabromocyclododecane $(\beta$-HBCD)

- $\gamma$-hexabromocyclododecane $(\gamma$-HBCD)

- 2,2',4,4'-tetrabromodiphenyl ether (BDE-47)

- 2,2',3,4,4'-pentabromodiphenyl ether (BDE-85)

- 2,2',4,4',5-pentabromodiphenyl ether (BDE-99)

- 2,2',4,4',6-pentabromodiphenyl ether (BDE-100)

- 2,2',4,4',5,5'-hexabromodiphenyl ether (BDE-153)

- 2,2',4,4',5,6'-hexabromodiphenyl ether (BDE-154)

- 2,2',3,4,4',5',6-heptabromodiphenyl ether (BDE-183)

- 2,2',3,3',4,4',5,5',6-nonabromodiphenyl ether (BDE-206)

- decabromodiphenyl ether (BDE-209)

- 1,2-Bis(2,4,6-tribromophenoxy)ethane (BTBPE)

- decabromodiphenyl ethane (DBDPE)

- 2-ethylhexyl 2,3,4,5-tetrabromobenzoate (EH-TBB)

- tetrabromobisphenol A (TBBPA)

- $\operatorname{Bis}(2-e t h y l h e x y l)$ tetrabromophthalate (BEH-TEBP)

- tricresyl phosphate (TCP)

- Tris(chloroethyl) phosphate (TCEP)

- Tris(2-chloroisopropyl) phosphate (TCIPP)

- tris-(1,3-dichloro-2-propyl) phosphate (TDCIPP)

- Tris(phenyl) phosphate (TPHP)

\section{Air Samples for Flame Retardants}

We collected two full-shift personal air samples per participant on two consecutive days. We collected the air samples for flame retardants on an Institute of Medicine (IOM) sampler with a glass fiber filter at a flow rate of 2 liters per minute. The IOM sampler collects the inhalable fraction of particulates. A contract lab analyzed the samples for the same flame retardants that were analyzed from the hand wipes according to an internal method [La Guardia and Hale 2015]. 
We also collected two area air samples for two days for the vapor-phase of flame retardants on custom OVS-2 tubes, which contained a glass fiber filter and two XAD-2 sorbent layers with glass wool separators at a flow rate of 1 liter per minute. Although flame retardants may either be particulates or semivolatile, more than $99 \%$ of the organophosphates in indoor air are expected to be particulates [Carlsson et al. 1997]. In addition, the lower brominated congeners (e.g., 2,2',4'-tribromodiphenyl ether (BDE-17) and 2,4,4'-tribromodiphenyl ether (BDE-28) are more likely to be in the vapor phase at room temperature, but the higher congeners such as BDE-99 and BDE-153 are predominately particulates [Allen et al. 2007]. BDE-209, for example, is almost entirely in the particulate phase. PBDEs, BTBPE, TBBPA, TPHP, and TCEP are present in primarily the particle-associated phase rather than the semivolatile phase [Sjödin et al. 2001].

\section{Blood Samples for Flame Retardants and Metals}

We collected approximately $30 \mathrm{~mL}$ of blood from each participant at the end of their shift at the end of the workweek. A trained technician drew venous blood into 2 serum separating tubes and 1 whole blood tube. We sent one tube of serum to the National Center for Environmental Health (NCEH) laboratory for analysis for PBDEs, polychlorinated biphenyls (PCBs), persistent pesticides (PPs), and cholesterol and triglycerides. PBDEs included BDE 47, BDE-85, BDE-99, BDE-100, BDE-153, BDE-154, BDE-183, and BDE-209. Measurements for BDE-17 and BDE-128 in the blood are not reported, because we could not measure and compare to air and handwipe levels. Cholesterol and triglycerides were measured to adjust brominated flame retardant, PCB, and PP levels for body fat. We sampled for PCBs and PPs to address the possibility of dietary effects on the levels of the PBDEs. If the participant gave us their consent, we stored the second serum separating tube of blood for future evaluation not related to the current health hazard evaluation. The tube of whole blood was sent to a commercial laboratory to be analyzed for blood lead and cadmium levels. Four employees routinely disassembled flat panel displays, and those employees' blood samples were analyzed for indium.

\section{Urine Samples for Flame Retardants}

We collected preshift and postshift urine samples on each day that air and hand wipe sampling for flame retardants was done. Each urine sample was collected in a sterile, $250 \mathrm{~mL}$ plastic cup. We measured the specific gravity of each sample, shook it, then aliquoted $30 \mathrm{~mL}$ into two separate containers. One was sent to the $\mathrm{NCEH}$ laboratory for analysis of the following flame retardant metabolites:

- diphenyl phosphate (DPHP) - a metabolite of TPHP

- bis(1,3-dichloro-2-propyl) phosphate (BDCIPP) - a metabolite of TDCIPP

- bis(1-chloro-2-propyl) phosphate (BCIPP) - a metabolite of TCIPP

- bis(2-chloroethyl) phosphate (BCEP) - a metabolite of TCEP

- di-pcresylphosphate (DpCP) - a metabolite of TCP

- di-o-cresylphosphate (DoCP) - a metabolite of TCP 
- 2,3,4,5-tetrabromobenzoic acid (TBBA) - a metabolite of EH-TBB

These analyses were conducted using the approach reported by Jayatilaka et al. [2017]. We used the reference range values in urine for the flame retardant metabolites for the U.S. population ages 20-59 as described in Ospina et al. [2018]. The second container was stored for future evaluation if the employee gave us consent.

\section{Statistical Analysis}

We used the American Industrial Hygiene Association IHstats V229 and SAS version 9.3 software for data analysis. Flame retardant wipe and air sample data were corrected for recoveries reported by the laboratory on three replicate spikes (100 nanograms per sample [ng/sample]) on blank wipes. For sample results that were reported as "not detected (ND)" we used the laboratory reporting limit divided by the square root of 2 [Hornung and Reed 1990] as the estimate. We examined the distributions of the air, hand wipe, and urine data. Some were normally distributed, some were log normally distributed, and some were neither; therefore, we reported medians, geometric means (GM), and ranges. We did not calculate GMs unless $70 \%$ or more of the samples had detectable results. We did not report medians or GMs if the sample size was five or less. Comparisons of medians or GMs were based simply on observation. Statistical testing was not done due to the small number of participants in the study. The reporting limits were $16 \mathrm{ng} / \mathrm{sample}$ for TCEP, TCIPP, and TDCIPP, $6.3 \mathrm{ng} / \mathrm{sample}$ of HBCD, and $1 \mathrm{ng} / \mathrm{sample}$ for the remainder of the air samples. The reporting limits for hand wipe samples were $63 \mathrm{ng} / \mathrm{sample}$ for HBCD, $156 \mathrm{ng} / \mathrm{sample}$ for TCEP, TCIPP, and TDCIPP, and $10 \mathrm{ng} / \mathrm{sample}$ for the remainder of the wipe samples. We assessed the efficiency of the repeat hand wipes by adding the sample results for each flame retardant from the three consecutive hand wipes, then calculated the percentage that was removed by each wipe. We compared the levels of urine and serum flame retardant biomarkers with the general population using the National Health and Nutrition Examination Survey (NHANES) data [ACGIH 2018; NIOSH 2014a; Ospina et al. 2018; Sjodin et al. 2008]. We reported GMs for the study participants and the general population using relevant age ranges. We also reported creatinine corrected urinary concentrations to account for individual variation. Both methods have been used for comparisons in the literature.

\section{Workplace Observations, Ergonomic Hazards, and Noise}

We reviewed job hazard analyses and observed work tasks to identify possible ergonomic stressors. We used a Larson Davis ${ }^{\circledR}$ model 831 sound level meter to measure peak sound levels during operation of the metal trash compactor, baler, and shredder. Measurements were taken during dumping of metal scrap into the compactor, compactor operation, baler operation, and shredding of hard drives. We positioned the sound level meter at a height of approximately 3-5 feet and within 3-6 feet of the primary noise source. 


\section{Results}

\section{Participant Characteristics}

Nineteen employees volunteered for this evaluation; three were female. The average age of participants was 39.5 years (range: $23-57$ ) and the median length of time in this company was 76 months (range: 3 months to 151 months). Participants usually worked 40 hours per week (range: 40-42 hours). Duties involved disassembly (eight participants), sorting (one), administrative office work (five), refurbishing (five), resale (two), floating (one), and shredding (one). Some participants rotated to other duties as needed, resulting in more than one job duty on a specific day. Three employees reported that they currently smoked. We asked employees about handwashing, the use of gloves, and if they took their work clothes and shoes home with them. Responses to these questions are shown in Table 1.

Table 1. Handwashing and use of work clothes, gloves, and shoes, reported by staff $(n=19)$

\begin{tabular}{lc}
\hline Work characteristic & Number $(\%)$ \\
\hline Wear work clothing home & $17(89)$ \\
Wear work shoes home & $15(79)$ \\
Wear gloves at work & $12(63)$ \\
$\quad$ Always & $5(42)$ \\
Most or some of the time & $7(58)$ \\
Reuse gloves at work & $12(100)$ \\
Wash hands at work & $19(100)$ \\
More than 5 times per day & $3(16)$ \\
4 or 5 times & $7(37)$ \\
3 or fewer times & $9(47)$ \\
Wash hands before eating at work & $19(100)$ \\
Always & $16(84)$ \\
Most or some of the time & $3(16)$ \\
Wash hands before leaving work & $19(100)$ \\
Always & $11(58)$ \\
Sometimes or never & $8(42)$ \\
\hline
\end{tabular}

\section{Surface and Hand Wipe Sampling for Metals}

We wiped surfaces outside of the processing area to determine if metals were inadvertently transferred or had migrated from the processing area. We wiped surfaces inside the processing area to determine possible sources of the contamination. We found the presence of lithium on only one non-processing surface and lead on only five non-processing surfaces. The levels of lead and lithium were all relatively low (Table 2). We did not detect beryllium, cadmium, or indium on any non-processing surfaces. The highest lead levels in the 
processing areas were at the disassembly workstation by the shredder ( 31 micrograms per 100 square centimeters $\left.\left[\mu \mathrm{g} / 100 \mathrm{~cm}^{2}\right]\right)$, disassembly workstation after cleaning $\left(26 \mu \mathrm{g} / 100 \mathrm{~cm}^{2}\right)$, and on the lithium ion battery workstation $\left(19 \mu \mathrm{g} / 100 \mathrm{~cm}^{2}\right)$.

Table 2. Surface wipe samples for selected metals in $\mu \mathrm{g} / 100 \mathrm{~cm}^{2}$

\begin{tabular}{|c|c|c|c|c|c|}
\hline Sample location & Beryllium & Cadmium & Indium & Lead & Lithium \\
\hline \multicolumn{6}{|l|}{ Non-processing areas } \\
\hline Upper breakroom - table & ND & ND & ND & ND & ND \\
\hline Upper breakroom - counter & ND & ND & ND & ND & ND \\
\hline Upper breakroom - microwave* & ND & ND & ND & 0.34 & ND \\
\hline Upper breakroom - freezer handle* & ND & ND & ND & 1.1 & ND \\
\hline Upper breakroom - counter & ND & ND & ND & ND & ND \\
\hline Upper breakroom - table & ND & ND & ND & ND & ND \\
\hline Lower breakroom - refrigerator handle* & ND & ND & ND & 1.2 & ND \\
\hline Lower breakroom - counter by sink & ND & ND & ND & ND & ND \\
\hline Lower breakroom - coffee table & ND & ND & ND & ND & ND \\
\hline Computer room - table & ND & ND & ND & ND & ND \\
\hline Lower breakroom - door men's restroom & ND & ND & ND & 0.34 & ND \\
\hline Lower breakroom - door women's restroom & ND & ND & ND & ND & 0.10 \\
\hline Push bar to the production floor* & ND & ND & ND & ND & ND \\
\hline Disassembly women's restroom* & ND & ND & ND & 0.22 & ND \\
\hline Disassembly men's restroom & ND & ND & ND & ND & ND \\
\hline \multicolumn{6}{|l|}{ Processing areas } \\
\hline Lithium Ion battery workstation & 0.017 & 0.63 & ND & 19 & 7.1 \\
\hline Indium downdraft table & ND & ND & ND & 0.29 & 0.11 \\
\hline Disassembly workstation, after cleaning & 0.029 & 16 & 0.88 & 26 & 0.98 \\
\hline Disassembly workstation, by shredder & ND & 4.7 & 0.34 & 31 & 1.9 \\
\hline $\begin{array}{l}\text { Table } 2 \text { nd floor, where hand wipes } \\
\text { collected }\end{array}$ & ND & ND & ND & ND & ND \\
\hline Inventory station 1 , clean workstation left & ND & 0.14 & 0.56 & 2.9 & ND \\
\hline Inventory station 3 , left side of desk & ND & 0.24 & 0.46 & 2.7 & 0.64 \\
\hline Refurb station 1 , closest to shredder $†$ & ND & ND & ND & 1.0 & 0.4 \\
\hline Refurb station 1 , closest to shredder & ND & ND & ND & 0.46 & 0.12 \\
\hline Cellphone refurb station & ND & ND & ND & 0.68 & 0.19 \\
\hline Limit of detection & 0.005 & 0.03 & 0.3 & 0.2 & 0.1 \\
\hline Limit of quantification & 0.018 & 0.087 & 1.1 & 0.75 & 0.34 \\
\hline
\end{tabular}

${ }^{*}$ Estimated surface area

†Vacuum sample 
We detected metals on the hands of all processing employee participants after they washed their hands before leaving work at the end of the shift (Table 3). We found that lead had the highest mean and median concentrations in the hand wipes followed by lithium.

Employees working in the disassembly department $(n=8)$ had the highest median lead level $(0.72 \mu \mathrm{g} / \mathrm{sample})$ followed by employees working in the office/inventory/resale department $(\mathrm{n}=6)$ with a median level of $0.44 \mu \mathrm{g} /$ sample and finally employees working in the refurbishing department $(\mathrm{n}=5)$ with a median level of $0.34 \mu \mathrm{g} / \mathrm{sample}$. The results for the other metals followed a similar pattern.

Table 3. Hand wipe sample results for all employees $(n=19)$ in $\mu \mathrm{g} / \mathrm{sample}$ for selected metals

\begin{tabular}{lcc}
\hline Element & $\begin{array}{c}\text { Mean concentration* } \\
\text { (range) }\end{array}$ & Median concentration \\
\hline Beryllium & $0.012($ ND-0.02) & 0.011 \\
Cadmium & $0.15($ ND-0.27) & 0.14 \\
Indium & ND & ND \\
Lead & $0.99(0.23-3.2)$ & 0.64 \\
Lithium & $0.35($ ND-0.68) & 0.32 \\
\hline
\end{tabular}

*These calculations were based only on detected results.

\section{Air Samples for Metals}

We collected personal air samples for 32 elements for 19 employees over 2 days. No employees were exposed to any of these metals over the Occupational Safety and Health Administration (OSHA) permissible exposure limit (PEL), NIOSH recommended exposure limit (REL), or American Conference of Governmental Industrial Hygienists (ACGIH) threshold limit value (TLV). In addition, all of these employees' exposures were less than half of the lowest OEL. A table summarizing the employees' exposures can be found in Appendix A, Table A3. Neither beryllium nor indium were detected in any of the personal air samples. One inventory employee had lithium detected at 0.08 micrograms per cubic meter of air $\left(\mu \mathrm{g} / \mathrm{m}^{3}\right)$. The median cadmium concentration was under the limit of detection (range ND-0.03 $\mu \mathrm{g} / \mathrm{m}^{3}$ ) with the highest exposures on disassembly employees. Lead was detected in 24 of the 38 air samples with a median concentration of $0.14 \mu \mathrm{g} / \mathrm{m}^{3}$ (range ND- $0.37 \mu \mathrm{g} / \mathrm{m}^{3}$ ) with the highest exposures on the disassembly employees.

We took area air samples for metals in six processing locations (shredder, "special" refurb, inventory, lithium batteries, downdraft table, and disassembly) over 2 days. Beryllium and lithium were not detected in any of the area air samples. Cadmium was only detected at the "special" refurb station at $0.02 \mu \mathrm{g} / \mathrm{m}^{3}$. Lead was detected at the shredder $\left(0.23 \mu \mathrm{g} / \mathrm{m}^{3}\right)$, a disassembly station $\left(0.18 \mu \mathrm{g} / \mathrm{m}^{3}\right)$, and at the downdraft table $\left(0.14 \mu \mathrm{g} / \mathrm{m}^{3}\right)$. Indium was detected at a disassembly table $\left(5.6 \mu \mathrm{g} / \mathrm{m}^{3}\right)$, the "special" refurb station $\left(3.5 \mu \mathrm{g} / \mathrm{m}^{3}\right)$ and at an inventory station $\left(0.25 \mu \mathrm{g} / \mathrm{m}^{3}\right)$. 


\section{Blood Samples for Metals}

Nineteen employees had blood drawn for metals. Blood lead levels (BLLs) ranged from below the laboratory limit of detection of 0.5 to 4.7 micrograms per deciliter $(\mu \mathrm{g} / \mathrm{dL})$. Participants working in the disassembly department had slightly higher average BLLs $(2.0 \mu \mathrm{g} / \mathrm{dL})$ than non-disassembly employees $(1.1 \mu \mathrm{g} / \mathrm{dL})$. The NIOSH Adult Blood Lead Epidemiology and Surveillance System uses a surveillance case definition for an elevated BLL in adults of $5 \mu \mathrm{g} / \mathrm{dL}$ or higher [CDC 2015a]. No participants exceeded this reference value, though one disassembly employee approached the level with a BLL of $4.7 \mu \mathrm{g} / \mathrm{dL}$. Blood cadmium levels were low, with all but four below the laboratory limit of detection of 0.5 micrograms per liter $(\mu \mathrm{g} / \mathrm{L})$. Three employees with detectable levels of cadmium worked in the disassembly department. All four blood indium levels collected were below the limit of detection $(0.5 \mu \mathrm{g} / \mathrm{L})$.

\section{Hand Wipe and Surface Wipe Sampling for Flame Retardants}

Table 4 summarizes the results of the preshift and postshift hand wipe sampling for flame retardants taken on 2 subsequent days for each of the departments. In general, we found higher median levels of the flame retardants categorized as "commonly used in electronics now and in the past" in the postshift samples from disassembly employees and refurbishing employees, but not in resale or office employees. We saw a similar trend for the primary DecaBDE congener (BDE-209), which was commonly used in electronics until 2013, but not for BDE-206, which was not detected in sufficient quantity to calculate medians.

With the exception of BEH-TEBP and TCIPP, for flame retardants classified as "less commonly used now and in the past," we did not find a substantial difference between median levels in pre and postshift hand wipes. BEH-TEBP and TCIPP had higher median levels in disassembly, refurbishing, and office employees. Within this category of flame retardants, $\alpha, \beta, \gamma-\mathrm{HBCD}$ were only found in some of the postshift handwipe samples for disassembly employees, at very low levels.

When found in sufficient quantities to calculate median levels, we found very little difference between pre and postshift levels of the PentaBDE congeners (flame retardants categorized as rarely used in electronics). The congeners for OctaBDE flame retardants (commonly used in electronics until 2004) were found in very few of the samples and when found, were not detected in sufficient quantities to calculate medians in either the preshift or postshift measurements. 


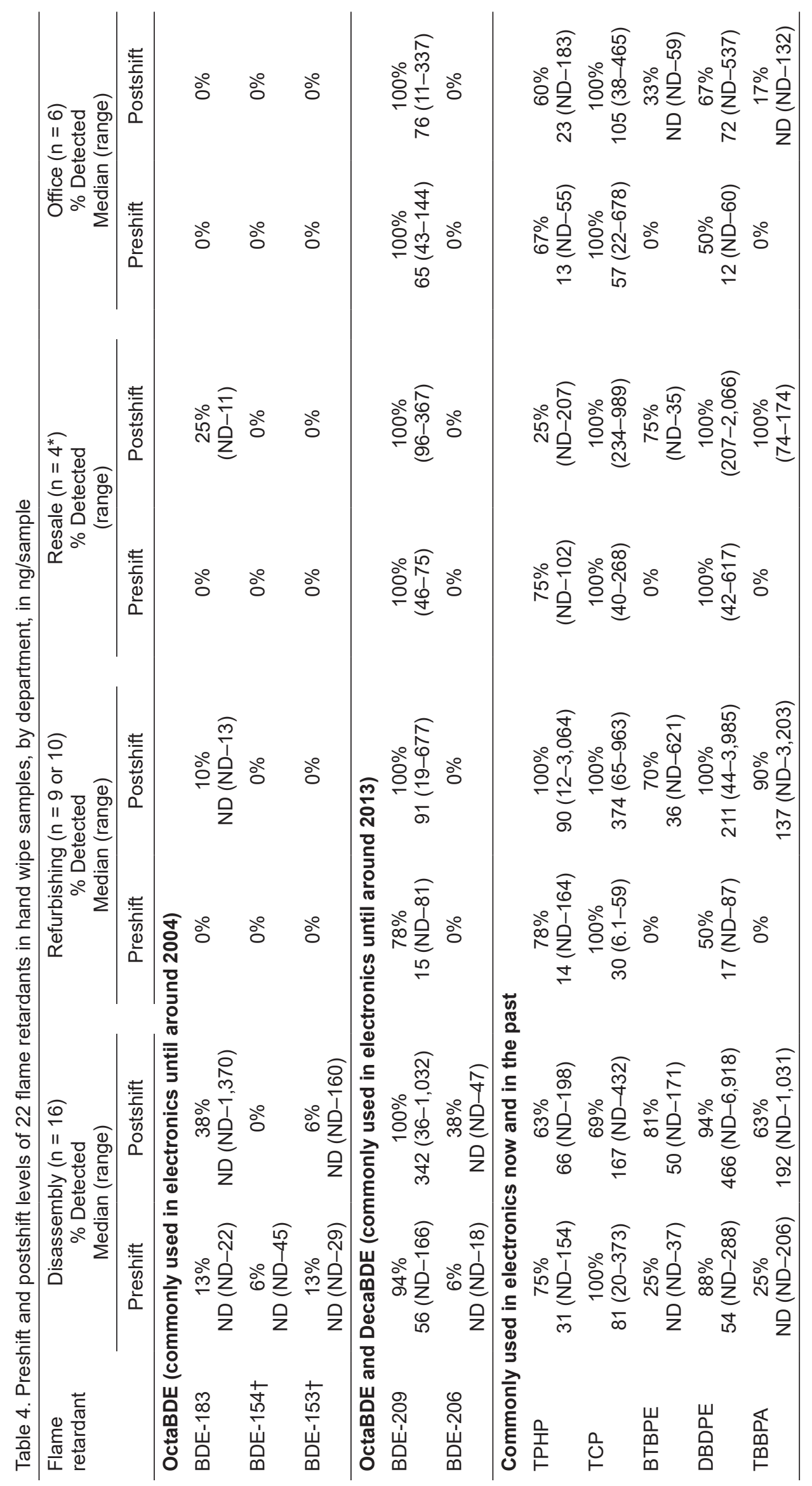




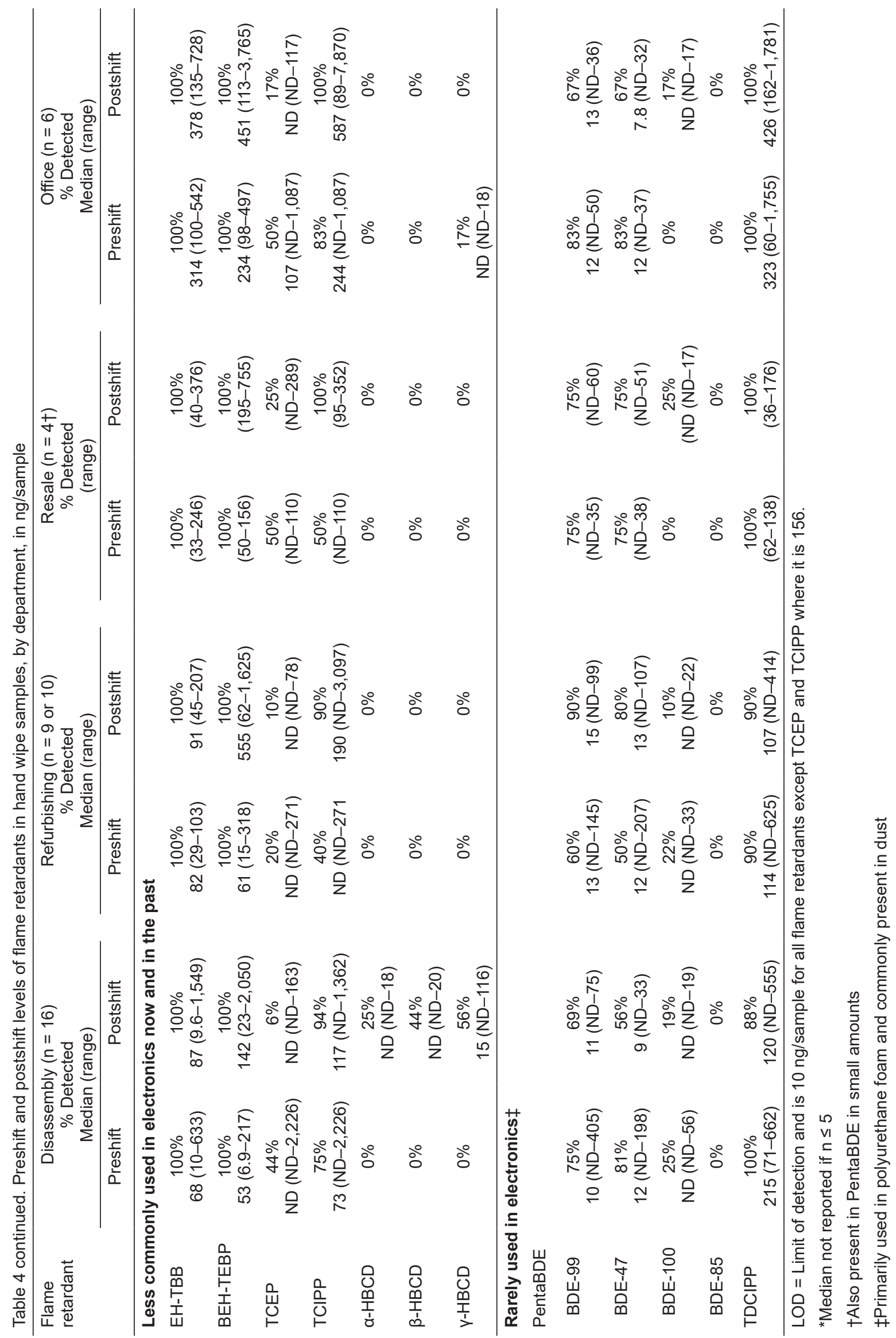


Table 5 shows the results of the surface wipe sampling collected throughout the facility. The area with the highest overall concentration of flame retardants was the disassembly workstation (12,051 nanograms per 100 square centimeters $\left.\left[\mathrm{ng} / 100 \mathrm{~cm}^{2}\right]\right)$, followed by in resale below the extruded polystyrene foam packing material delivery system (referred to as the "popcorn pooper")[10,945 $\left.\mathrm{ng} / 100 \mathrm{~cm}^{2}\right]$. A second disassembly workstation $\left(4,094 \mathrm{ng} / 100 \mathrm{~cm}^{2}\right)$, the triage table $\left(3,919 \mathrm{ng} / 100 \mathrm{~cm}^{2}\right]$, and the inventory table $\left(2,488 \mathrm{ng} / 100 \mathrm{~cm}^{2}\right)$ all had relatively lower levels of flame retardants on the surface. Lastly, the downdraft table $\left(625 \mathrm{ng} / 100 \mathrm{~cm}^{2}\right)$, resale workstation $\left(573 \mathrm{ng} / 100 \mathrm{~cm}^{2}\right)$, office workstation $\left(539 \mathrm{ng} / 100 \mathrm{~cm}^{2}\right)$, shredder $\left(487 \mathrm{ng} / 100 \mathrm{~cm}^{2}\right)$, refurbish workstation $(405 \mathrm{ng} / 100$ $\left.\mathrm{cm}^{2}\right)$, and the monitors testing workstation $\left(226 \mathrm{ng} / 100 \mathrm{~cm}^{2}\right)$ all had substantially less. The quality control workstation had no detectable flame retardants.

We found TCP $\left(13,618 \mathrm{ng} / 100 \mathrm{~cm}^{2}\right)$ in 11 of the 12 sample locations, the highest level $\left(9,079 \mathrm{ng} / 100 \mathrm{~cm}^{2}\right)$ was found in resale below the packing material delivery system and secondarily on the disassembly workstation. We found DBDPE $\left(3,638 \mathrm{ng} / 100 \mathrm{~cm}^{2}\right)$ primarily on the disassembly workstation. We found EH-TBB (554 $\left.\mathrm{ng} / 100 \mathrm{~cm}^{2}\right)$ predominately on the inventory workstation. The remainder of the flame retardants were mostly located in the disassembly area. 


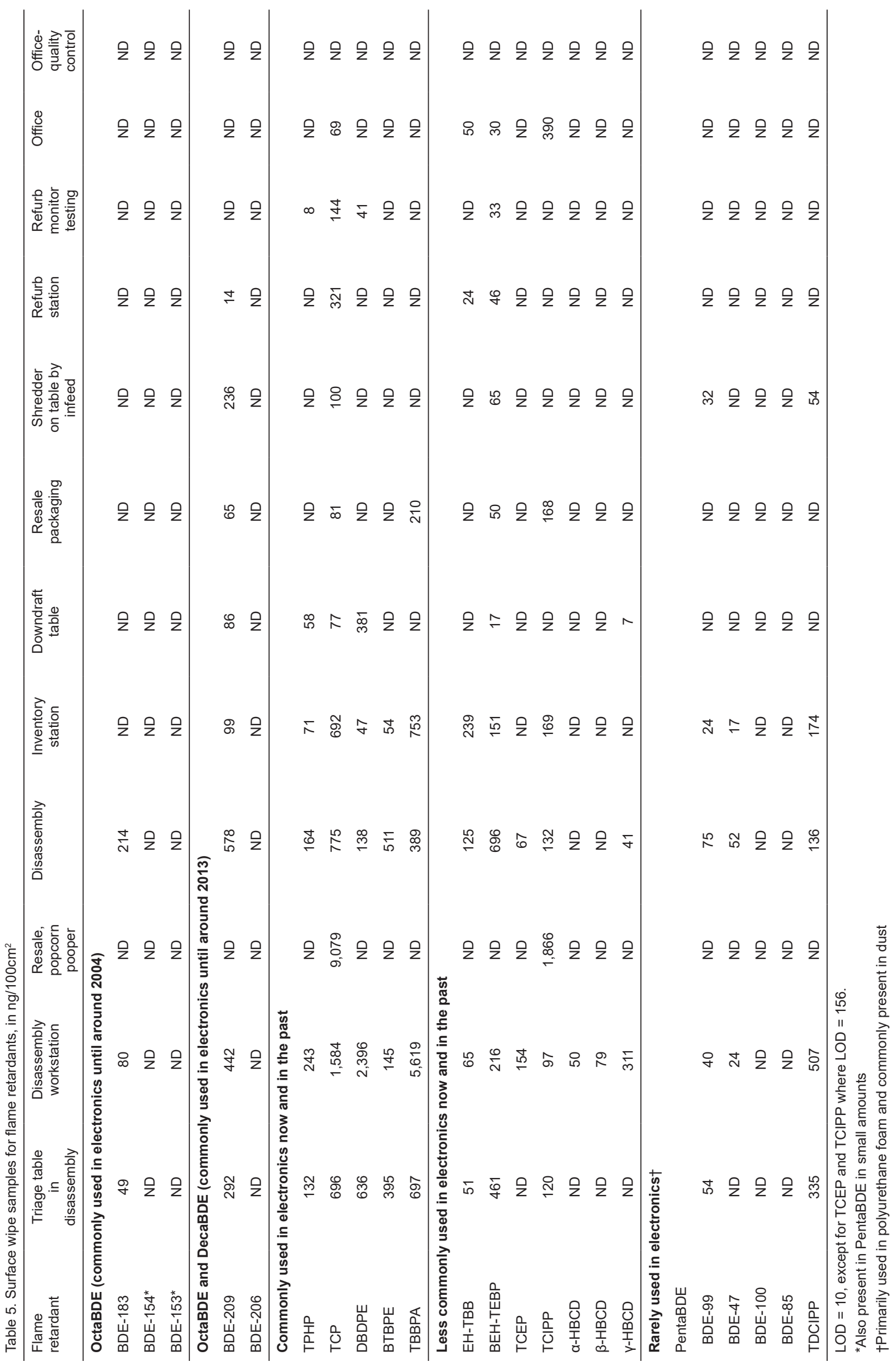




\section{Air Samples for Flame Retardants}

Results of personal air sampling for flame retardants are listed in Table 6. PBDEs are listed by technical mixture (i.e., OctaBDE) and by decreasing concentration of each congener within that mixture [Alaee et al. 2003; La Guardia et al. 2006]. The percentages of each congener in the technical mixtures are provided in Appendix A, Table A2. All full-shift personal air samples for flame retardants were low. TCIPP was detected in $95 \%$ of the air samples and had the highest relative median (22.5 nanograms per cubic meter $\left[\mathrm{ng} / \mathrm{m}^{3}\right]$ ) and GM $\left(19 \mathrm{ng} / \mathrm{m}^{3}\right)$ concentrations. TCP and TPHP were detected in $84 \%$ and $97 \%$ of the air samples respectively, with median concentrations of $7.3 \mathrm{ng} / \mathrm{m}^{3}$ and $8.8 \mathrm{ng} / \mathrm{m}^{3}$. No other flame retardants had sufficiently detectable results to calculate medians or GMs. 
Table 6. Full-shift personal air sampling results for 19 participants over 2 days ( $\mathrm{n}=38$ ), in $\mathrm{ng} / \mathrm{m}^{3}$

\begin{tabular}{|c|c|c|c|}
\hline Flame retardant & Median* & $\mathrm{GM}^{*}$ (range) & Number (\%) detected \\
\hline \multicolumn{4}{|c|}{ OctaBDE (commonly used in electronics until around 2004) } \\
\hline BDE-183 & ND & ND & $0(0)$ \\
\hline BDE-154† & ND & ND & $0(0)$ \\
\hline BDE-153† & ND & ND & $0(0)$ \\
\hline \multicolumn{4}{|c|}{ OctaBDE and DecaBDE (commonly used in electronics until around 2013) } \\
\hline BDE-209 & - & $(N D-120)$ & $23(61)$ \\
\hline BDE-206 & - & $(\mathrm{ND}-6.3)$ & $2(5)$ \\
\hline \multicolumn{4}{|c|}{ Commonly used in electronics now and in the past } \\
\hline TPHP & 4.8 & 7.3 (ND-690) & $32(84)$ \\
\hline TCP & 8.9 & $8.8(N D-71)$ & $37(97)$ \\
\hline DBDPE & - & (ND-84) & $11(29)$ \\
\hline BTBPE & - & (ND-15) & $7(18)$ \\
\hline TBBPA & - & $(\mathrm{ND}-63)$ & $24(63)$ \\
\hline \multicolumn{4}{|c|}{ Less commonly used in electronics now and in the past } \\
\hline EH-TBB & - & (ND-8.7) & $9(24)$ \\
\hline BEH-TEBP & - & $(\mathrm{ND}-13)$ & $23(61)$ \\
\hline TCEP & - & (ND-10) & $7(18)$ \\
\hline TCIPP & 23 & 19 (ND-102) & $36(95)$ \\
\hline $\operatorname{HBCD}(\alpha, \beta, \gamma)$ & ND & ND & $0(0)$ \\
\hline \multicolumn{4}{|c|}{ Rarely used in electronics $\ddagger$} \\
\hline \multicolumn{4}{|l|}{ PentaBDE } \\
\hline BDE-99 & - & (ND-8.4) & $24(63)$ \\
\hline BDE-47 & - & (ND-3.6) & $4(11)$ \\
\hline BDE-100 & - & (ND-7.0) & $23(61)$ \\
\hline BDE-85 & ND & ND & $0(0)$ \\
\hline TDCIPP & - & (ND-44) & $26(68)$ \\
\hline
\end{tabular}

The minimum detectable concentrations were calculated using an average volume of 943 liters $\left(1 \mathrm{ng} / \mathrm{m}^{3}\right)$ for all of the flame retardants except TCEP and TCIPP, which were $16 \mathrm{ng} / \mathrm{m}^{3}$.

${ }^{*}$ GMs and Medians were not calculated if percent detected was below $70 \%$.

†Also present in PentaBDE in small amounts

$\ddagger$ Primarily used in polyurethane foam and commonly present in dust 
Results of personal air sampling for flame retardants, stratified by department, are in Table 7. We did not detect any OctaBDE congeners or $\alpha, \beta, \gamma-\mathrm{HBCD}$ in the air samples on either day. In general, we detected more flame retardants in the disassembly employees' air samples than in the other departments. However, we found both flame retardants that are commonly used in electronics as well as flame retardants that are rarely used in electronics throughout the facility. Additionally, all median flame retardant concentrations were similar (within the same order of magnitude) regardless of the location of the sample collection. We found the highest median concentration of flame retardants $\left(31 \mathrm{ng} / \mathrm{m}^{3}\right.$ of TCIPP) in the office sample. TCIPP is typically found in polyurethane rigid and flexible foam. Refurbishing and disassembly also had TCIPP as the predominant flame retardant. TCP and BDE-209 were also present in the air samples from disassembly. PentaBDE congeners were detected in all of the sorting and inventory $(\mathrm{n}=2)$ air samples we collected. However, the highest relative concentration for any of the flame retardants in this department was TCIPP. 
Table 7. Concentrations of flame retardants in full-shift personal air samples, by department, over two days, in $\mathrm{ng} / \mathrm{m}^{3}$

\begin{tabular}{|c|c|c|c|c|}
\hline Flame retardant & $\begin{array}{c}\text { Disassembly }(n=16) \\
\% \text { Detected } \\
\text { Median (range) }\end{array}$ & $\begin{array}{c}\text { Refurbishing }(n=10) \\
\% \text { Detected } \\
\text { Median (range) }\end{array}$ & $\begin{array}{c}\text { Resale }\left(n=4^{*}\right) \\
\% \text { Detected } \\
\text { (range) }\end{array}$ & $\begin{array}{c}\text { Office }(\mathrm{n}=6) \\
\% \text { Detected } \\
\text { Median (range) }\end{array}$ \\
\hline \multicolumn{5}{|c|}{ OctaBDE (commonly used in electronics until around 2004) } \\
\hline BDE-183 & $0 \%$ & $0 \%$ & $0 \%$ & $0 \%$ \\
\hline BDE-154† & $0 \%$ & $0 \%$ & $0 \%$ & $0 \%$ \\
\hline BDE-153† & $0 \%$ & $0 \%$ & $0 \%$ & $0 \%$ \\
\hline \multicolumn{5}{|c|}{ OctaBDE and DecaBDE (commonly used in electronics until around 2013) } \\
\hline BDE-209 & $\begin{array}{c}75 \% \\
13(N D-120)\end{array}$ & $\begin{array}{c}50 \% \\
1.7(\mathrm{ND}-20)\end{array}$ & $\begin{array}{c}75 \% \\
(N D-23)\end{array}$ & $\begin{array}{c}33 \% \\
\text { ND (ND-6.4) }\end{array}$ \\
\hline BDE-206 & $\begin{array}{c}13 \% \\
\text { ND (ND-6.3) } \\
\end{array}$ & $0 \%$ & $0 \%$ & $0 \%$ \\
\hline \multicolumn{5}{|c|}{ Commonly used in electronics now and in the past } \\
\hline TPHP & $\begin{array}{c}94 \% \\
8.5(\mathrm{ND}-205)\end{array}$ & $\begin{array}{c}80 \% \\
7.4(\mathrm{ND}-87)\end{array}$ & $\begin{array}{c}75 \% \\
(N D-2.6)\end{array}$ & $\begin{array}{c}100 \% \\
20(1.0-690)\end{array}$ \\
\hline TCP & $\begin{array}{c}100 \% \\
17(3.0-71)\end{array}$ & $\begin{array}{c}100 \% \\
8.3(4.7-43)\end{array}$ & $\begin{array}{c}100 \% \\
(1.8-9.8)\end{array}$ & $\begin{array}{c}100 \% \\
6.0(2.9-30)\end{array}$ \\
\hline DBDPE & $\begin{array}{c}50 \% \\
3.0(N D-84)\end{array}$ & $0 \%$ & $\begin{array}{c}50 \% \\
(N D-30)\end{array}$ & $0 \%$ \\
\hline BTBPE & $\begin{array}{c}44 \% \\
\text { ND (ND-15) }\end{array}$ & $0 \%$ & $0 \%$ & $0 \%$ \\
\hline TBBPA & $\begin{array}{c}81 \% \\
2.8(N D-56) \\
\end{array}$ & $\begin{array}{c}50 \% \\
1.4(\mathrm{ND}-27) \\
\end{array}$ & $\begin{array}{c}50 \% \\
(N D-2.6) \\
\end{array}$ & $\begin{array}{c}50 \% \\
1.9(\mathrm{ND}-63) \\
\end{array}$ \\
\hline \multicolumn{5}{|c|}{ Less commonly used in electronics now and in the past } \\
\hline EH-TBB & $\begin{array}{c}31 \% \\
\text { ND (ND-8.7) }\end{array}$ & $0 \%$ & $\begin{array}{c}50 \% \\
(N D-1.6)\end{array}$ & $\begin{array}{c}33 \% \\
\text { ND (ND-2.6) }\end{array}$ \\
\hline BEH-TEBP & $\begin{array}{c}94 \% \\
2.4(\mathrm{ND}-13)\end{array}$ & $\begin{array}{c}60 \% \\
0.82(\mathrm{ND}-5.5)\end{array}$ & $\begin{array}{c}25 \% \\
(N D-1.9)\end{array}$ & $0 \%$ \\
\hline TCEP & $\begin{array}{c}19 \% \\
\text { ND (ND-10) }\end{array}$ & $\begin{array}{c}30 \% \\
\text { ND (ND-5.7) }\end{array}$ & $0 \%$ & $\begin{array}{c}17 \% \\
\text { ND (ND-10) }\end{array}$ \\
\hline TCIPP & $\begin{array}{c}94 \% \\
19(N D-45)\end{array}$ & $\begin{array}{c}100 \% \\
26(12-102)\end{array}$ & $\begin{array}{c}100 \% \\
(14-38)\end{array}$ & $\begin{array}{c}100 \% \\
31(14-77)\end{array}$ \\
\hline $\operatorname{HBCD}(\alpha, \beta, \gamma)$ & $0 \%$ & $0 \%$ & $0 \%$ & $0 \%$ \\
\hline \multicolumn{5}{|c|}{ Rarely used in electronics $\ddagger$} \\
\hline \multicolumn{5}{|l|}{ PentaBDE } \\
\hline BDE-99 & $\begin{array}{c}69 \% \\
1.5(N D-5.6)\end{array}$ & $\begin{array}{c}40 \% \\
\text { ND (ND-5.7) }\end{array}$ & $\begin{array}{c}50 \% \\
(N D-2.6)\end{array}$ & $\begin{array}{c}83 \% \\
2.1(\mathrm{ND}-8.4)\end{array}$ \\
\hline BDE-47 & $\begin{array}{c}13 \% \\
\text { ND (ND-3.6) }\end{array}$ & $\begin{array}{c}10 \% \\
\text { ND (ND-1.1) }\end{array}$ & $0 \%$ & $0 \%$ \\
\hline BDE-100 & $\begin{array}{c}56 \% \\
1.5(N D-5.1)\end{array}$ & $\begin{array}{c}60 \% \\
1.5(\mathrm{ND}-7.0)\end{array}$ & $\begin{array}{l}50 \% \\
(N D-5.0)\end{array}$ & $\begin{array}{c}67 \% \\
2.8(\mathrm{ND}-5.1)\end{array}$ \\
\hline BDE-85 & $0 \%$ & $0 \%$ & $0 \%$ & $0 \%$ \\
\hline TDCIPP & $\begin{array}{l}81 \% \\
3.4(\mathrm{ND}-27) \\
\end{array}$ & $\begin{array}{l}70 \% \\
3.2(N D-44)\end{array}$ & $\begin{array}{c}25 \% \\
(\mathrm{ND}-4.1)\end{array}$ & $\begin{array}{l}67 \% \\
2.4(\mathrm{ND}-15) \\
\end{array}$ \\
\hline \multicolumn{5}{|c|}{$\begin{array}{l}\text { The minimum detectable concentrations were calculated using an average volume of } 943 \text { liters } \\
\left(1 \mathrm{ng} / \mathrm{m}^{3}\right) \text { for all of the flame retardants except TCEP and TCIPP, which were } 16 \mathrm{ng} / \mathrm{m}^{3} \text {. }\end{array}$} \\
\hline \multicolumn{5}{|c|}{${ }^{*}$ Median not reported if $\mathrm{n} \leq 5$} \\
\hline \multicolumn{5}{|c|}{ †Also present in PentaBDE in small amounts } \\
\hline †Primarily used in & Dlyurethane foam and c & nly present in dust & & \\
\hline
\end{tabular}


The results of the area air sampling to evaluate the vapor-phase of the flame retardants had fewer detected flame retardants than the particulate phase samplers. We collected the samples at the shredder ( 3 samples) and inside the trailer used to store compressed plastic computer housings ( 1 sample). The only flame retardants detected over the minimum detectable concentrations were BDE-85 $\left(0.57 \mathrm{ng} / \mathrm{m}^{3}\right)$, TCP $\left(20 \mathrm{ng} / \mathrm{m}^{3}\right)$ and TPHP $\left(2.1 \mathrm{ng} / \mathrm{m}^{3}, 7.4 \mathrm{ng} / \mathrm{m}^{3}\right.$, $11 \mathrm{ng} / \mathrm{m}^{3}$, and $37 \mathrm{ng} / \mathrm{m}^{3}$ ).

\section{Blood Samples for Flame Retardants}

All 19 employees had blood drawn for PBDEs. Table 8 shows the serum PBDE concentrations in our participants for eight different polybrominated flame retardants.

The table also shows the serum PBDE concentrations found in the NHANES, which is a representative sample of the general population. The highest median and GM serum PBDE concentrations in our participants were for BDE-47, BDE-153, and BDE-209. In addition, all 19 of the participants had BDE-47, BDE-153, and BDE-100 detected in their blood serum. All GM and maximum values fell below comparison values from NHANES, though the GM for BDE-153 was only slightly lower than the comparison value. The GM concentration of BDE-209 was 3.0 nanograms per gram (ng/g) lipid weight in our participants, which was below the LOD of $5.8 \mathrm{ng} / \mathrm{g}$ lipid weight in the NHANES. 
Table 8. PBDE concentrations in serum of electronics recycling employees and in the National Health and Nutrition Examination Survey, in ng/g lipid weight

\begin{tabular}{|c|c|c|c|c|c|c|}
\hline & \multicolumn{3}{|c|}{$\begin{array}{l}\text { Electronics recycling company } \\
\text { participants }(n=19)\end{array}$} & \multicolumn{3}{|c|}{$\begin{array}{c}\text { National Health and } \\
\text { Nutrition Examination Survey* } †\end{array}$} \\
\hline & Median & GM & Max & Median & GM & $\begin{array}{c}\text { 95th } \\
\text { percentile }\end{array}$ \\
\hline \multicolumn{7}{|c|}{ OctaBDE (commonly used in electronics until around 2004) } \\
\hline BDE-183 & 0.33 & 0.33 & 1.2 & $\begin{array}{l}\text { Not } \\
\text { reported }\end{array}$ & $<1.7$ & ND $(<1.7)$ \\
\hline BDE-154§ & 0.16 & $\begin{array}{l}\text { Not } \\
\text { calculated }\end{array}$ & 0.68 & $\begin{array}{l}\text { Not } \\
\text { reported }\end{array}$ & $<0.8$ & 4.20 \\
\hline BDE-153§ & 4.57 & 4.74 & 19.2 & 4.40 & 5.41 & 73.3 \\
\hline \multicolumn{7}{|c|}{ OctaBDE and DecaBDE (commonly used in electronics until around 2013) } \\
\hline BDE-209ף & 2.87 & 2.95 & 27.6 & $\begin{array}{r}\text { Pooled san } \\
\text { high }\end{array}$ & $\begin{array}{l}\text { o mear } \\
\text { rtion of }\end{array}$ & $\begin{array}{l}\text { ulated due to } \\
<5.8)\end{array}$ \\
\hline \multicolumn{7}{|c|}{ PentaBDE (rarely used in electronics) ${ }^{* *}$} \\
\hline BDE-99 & 0.84 & 0.89 & 6.04 & $\begin{array}{l}\text { Not } \\
\text { reported }\end{array}$ & $<5.0$ & 41.6 \\
\hline BDE-47 & 5.05 & 5.25 & 34.7 & 18.0 & 19.5 & 163.0 \\
\hline BDE-100 & 1.51 & 1.35 & 9.23 & 3.30 & 3.77 & 36.6 \\
\hline BDE-85 & 0.13 & $\begin{array}{c}\text { Not } \\
\text { calculated }\end{array}$ & 0.81 & $\begin{array}{l}\text { Not } \\
\text { reported }\end{array}$ & $<2.4$ & 4.10 \\
\hline
\end{tabular}

${ }^{*}$ Age 20 and older

†Samples taken 2003 and 2004

‡GM not calculated if detected in less than $70 \%$ of samples

§Also present in PentaBDE in small amounts.

TIData from 2007-2008 NHANES

**Primarily used in polyurethane foam and commonly present in dust 
We sampled for PCBs and PPs to address the possibility of dietary effects on the levels of the PBDEs. Appendix A, Tables A4 and A5 show the concentrations of serum PCBs and PPs in our participants and the concentrations found in NHANES. Serum PCB levels were $35 \%-75 \%$ lower in our participants than the NHANES comparison values. Similarly, PP levels were $21 \%-50 \%$ less in participants, or were not detectable.

\section{Urine Samples for Flame Retardants}

The results of urine testing for metabolites of certain flame retardants by departments are shown in Table 9 (creatinine uncorrected concentrations in $\mu \mathrm{g} / \mathrm{L}$ ) and Table 10 (creatinine corrected concentrations in micrograms per gram $[\mu \mathrm{g} / \mathrm{g}]$ creatinine). Creatinine correction is done to adjust for individual variation in urine concentration. Uncorrected concentrations of DPHP in the postshift samples were slightly less than preshift concentrations in the disassembly, refurbishing, and office departments. However, the creatinine corrected values showed that levels were similar preshift and postshift in all departments. DpCP and DoCP, metabolites of TCP, were undetectable in most participants. We did not detect TBBA, the metabolite of EH-TBB, in the urine of any participants. Median uncorrected concentrations of BCEP, the metabolite of TCEP, declined slightly in disassembly, refurbishing, and office workers. Again, creatinine corrected values showed that levels were similar for these departments pre and postshift. Only refurbishing employees had a consistent decline across the shift. BDCIPP, the metabolite of TDCIPP, was detected in nearly all urine samples, and median concentrations declined for disassembly, refurbishing, and office employees, but remained steady across the shift for resale employees. Creatinine corrected results showed a consistent decline across the shift in refurbishing and office employees.

We also compared the results for the second day postshift urinary metabolite measurements for the electronics recycling company employees to the general population in Appendix A, Table A6 (uncorrected concentrations in $\mu \mathrm{g} / \mathrm{L}$ ) and Table A7 (creatinine corrected concentrations in $\mu \mathrm{g} / \mathrm{g}$ creatinine). Overall, median concentrations of the flame retardants tested for in the urine were similar to or lower than NHANES values. 


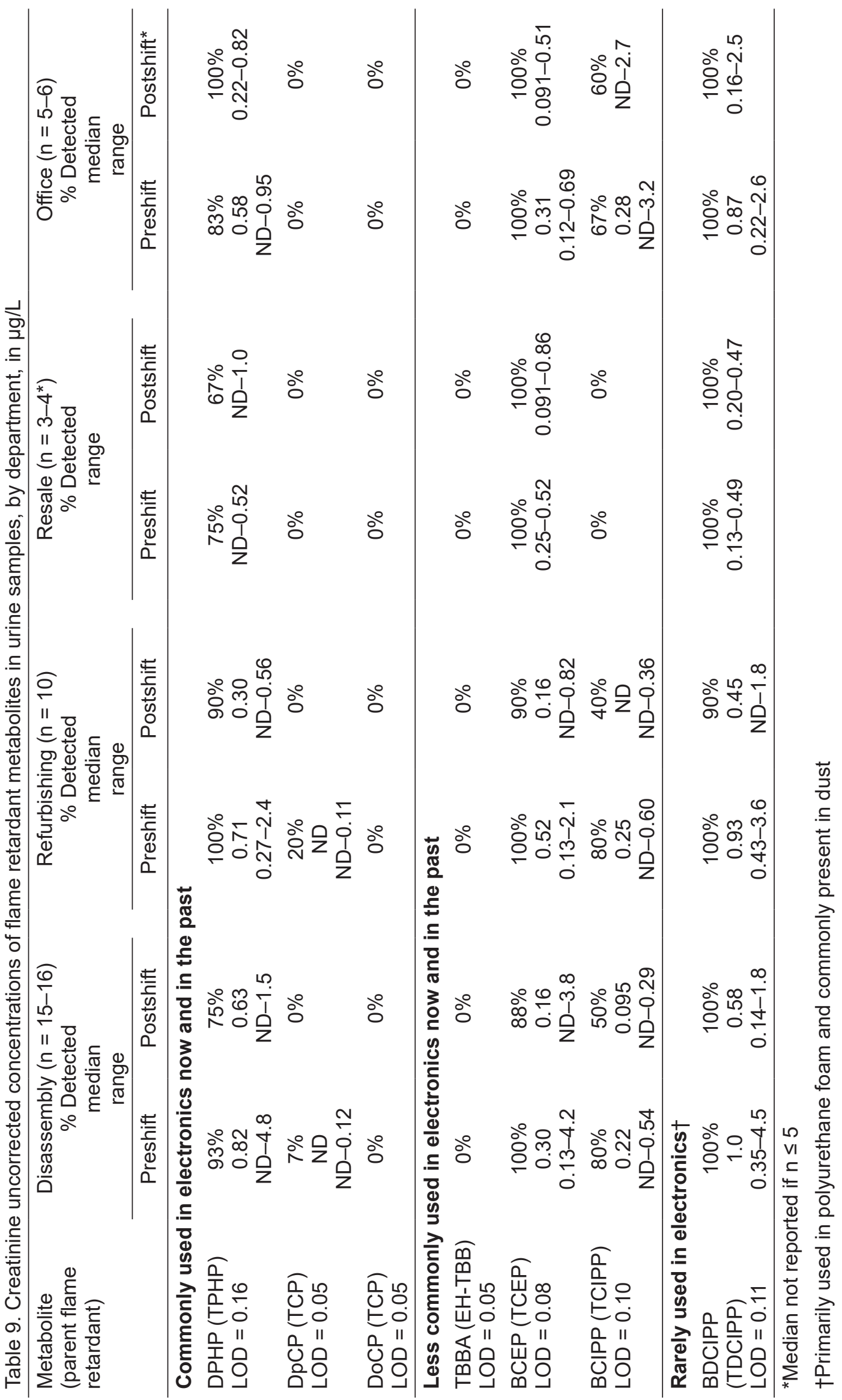




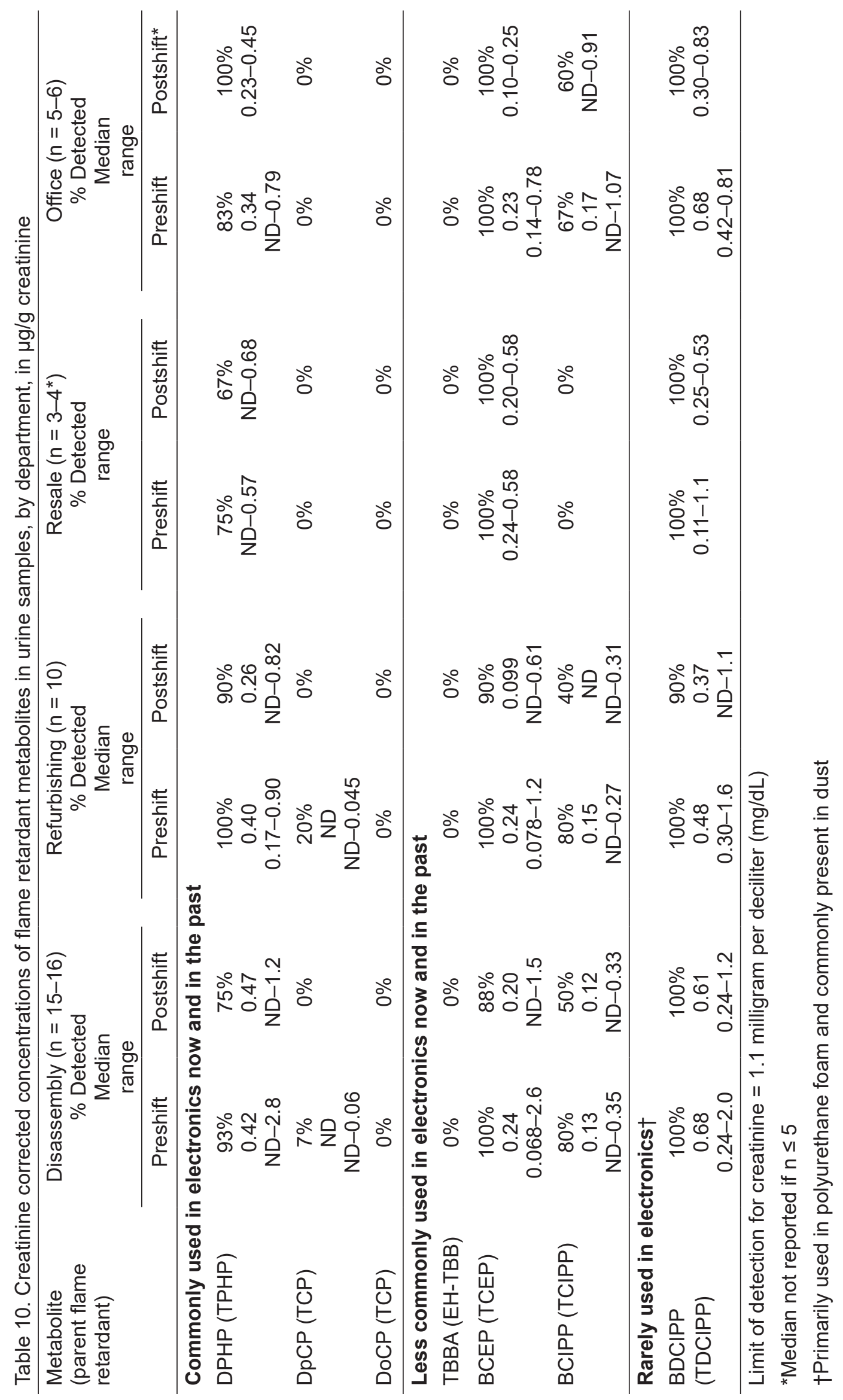




\section{Workplace Observations and Ergonomic Hazards}

The company completed a job hazard analysis for all departments or tasks. Each job hazard analysis included the recommended PPE; specifically, safety glasses, steel-toed boots, cutresistant gloves, chemical-resistant gloves, ear plugs, and voluntary use of N95 filtering facepiece respirators. We observed employees wearing ear plugs and respirators incorrectly. For example, employees did not fully insert ear plugs into the ear canal. Employees had been trained on using and storing respirators. However, we observed that some respirators were stored incorrectly in open boxes. Employees had received a copy of Appendix D of the OSHA respiratory protection standard (29 Code of Federal Regulation [CFR] 1910.134).

The company did not provide uniforms or have shower facilities, laundry facilities, or locker rooms and employees were permitted to wear their work clothes home. The employees ate lunch inside a break room, which was equipped with a sink. The office portion of the facility had a separate ventilation system from the warehouse. Employees were permitted to have water bottles and other drinks on the processing floor even though they had a break room; however, the drink had to be covered (Figure 1).

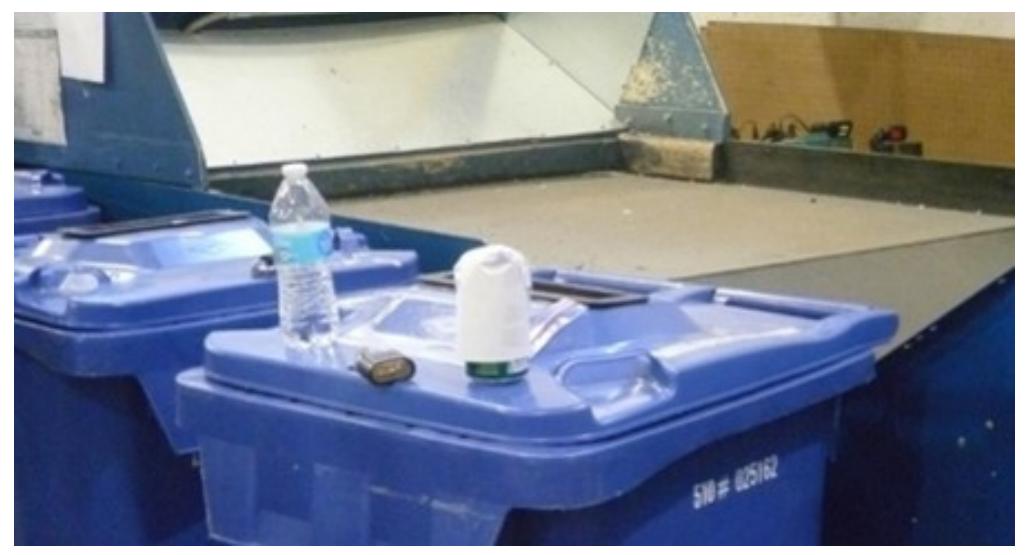

Figure 1. Can of soda covered with a makeshift paper cover. Photo by NIOSH.

The facility used shredders to mechanically destroy hard drives. During the first site visit, we observed that the facility used a large shredder with a conveyor system. This process sometimes created sparks inside the vertical hopper which traveled to the conveyor and potentially into the cardboard collection box at the end of the conveyor (Figure 2). The facility stopped using the large shredder and conveyor system shortly after our November 2016 site visit and replaced it with a smaller hard drive shredder (Figure 3). 


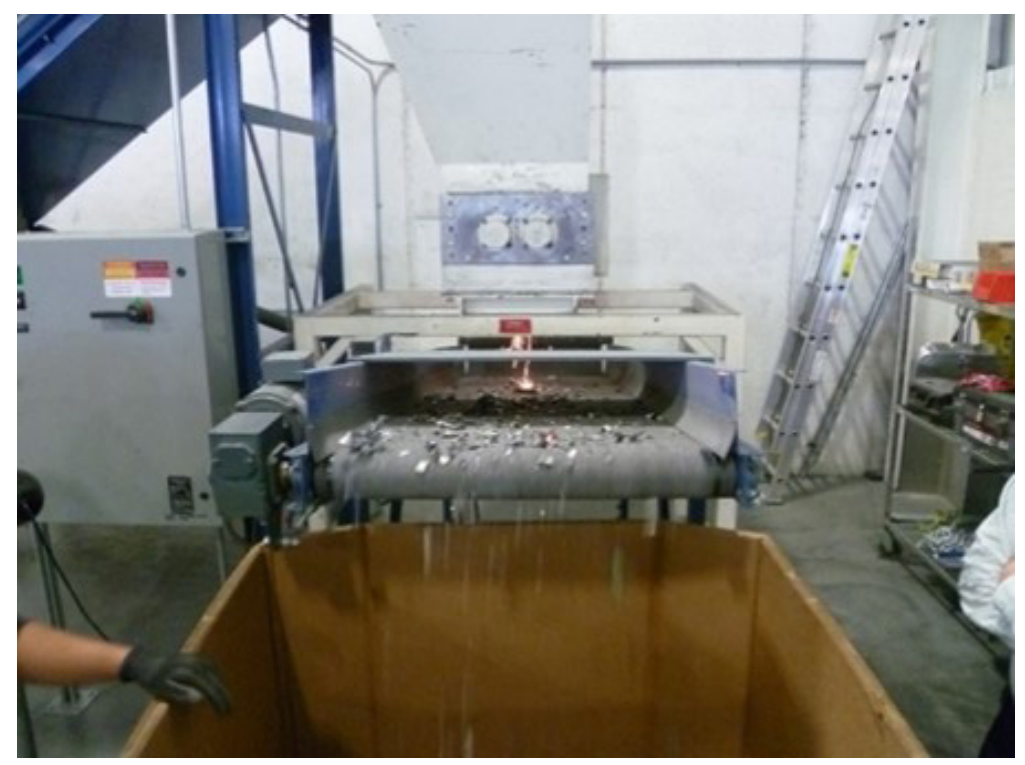

Figure 2. Sparks created from shredding hard drives in the large shredder were visible on the conveyor and could potentially be conveyed to the cardboard box used to collect shredded material. Photo by NIOSH.

When using the small hard drive shredder, employees manually transferred hard drives from a 50-gallon tote into smaller totes, which were placed onto a scissor lift table (Figure 3). When the 50-gallon tote was almost empty, employees placed the tote on its side and then used a tool to pull the hard drives from the bottom of the 50-gallon tote into the small tote (Figure 4). Because both the 50-gallon and the small tote were on the ground, we observed employees bending at the waist to complete this task, which placed their backs in an awkward position and increased the likelihood of back injury.

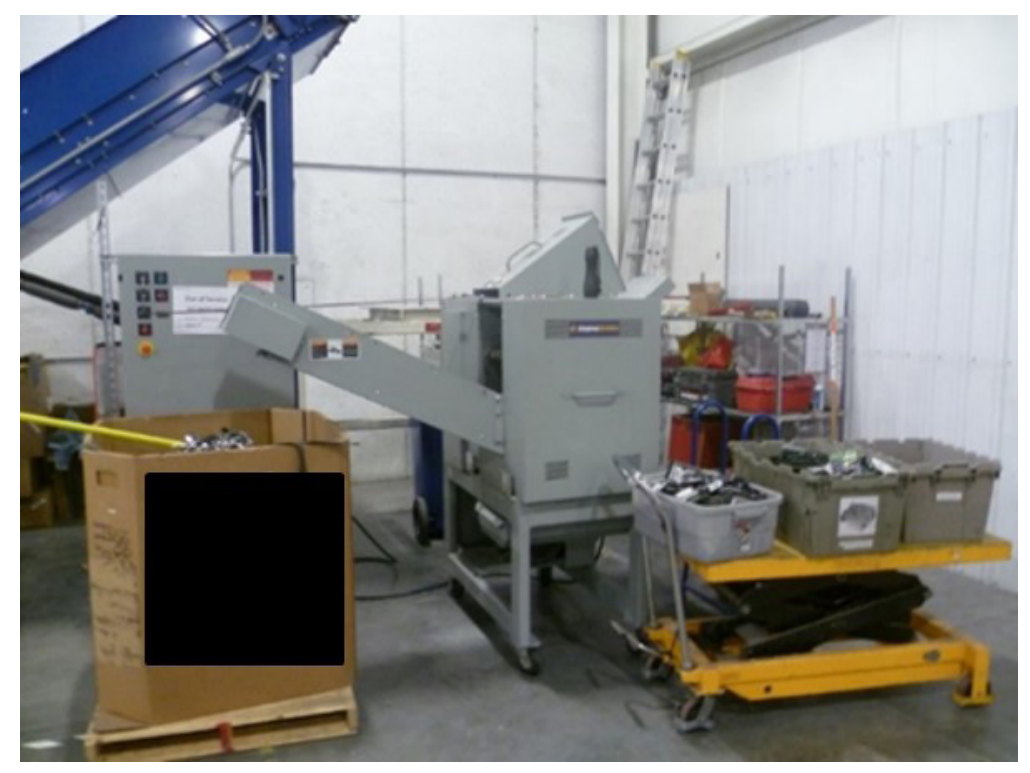

Figure 3. Hard drives shredded by the small shredder are dumped into a large cardboard box. The hard drives in the small totes on top of the scissor lift were waiting to be placed into the shredder. Photo by NIOSH. 


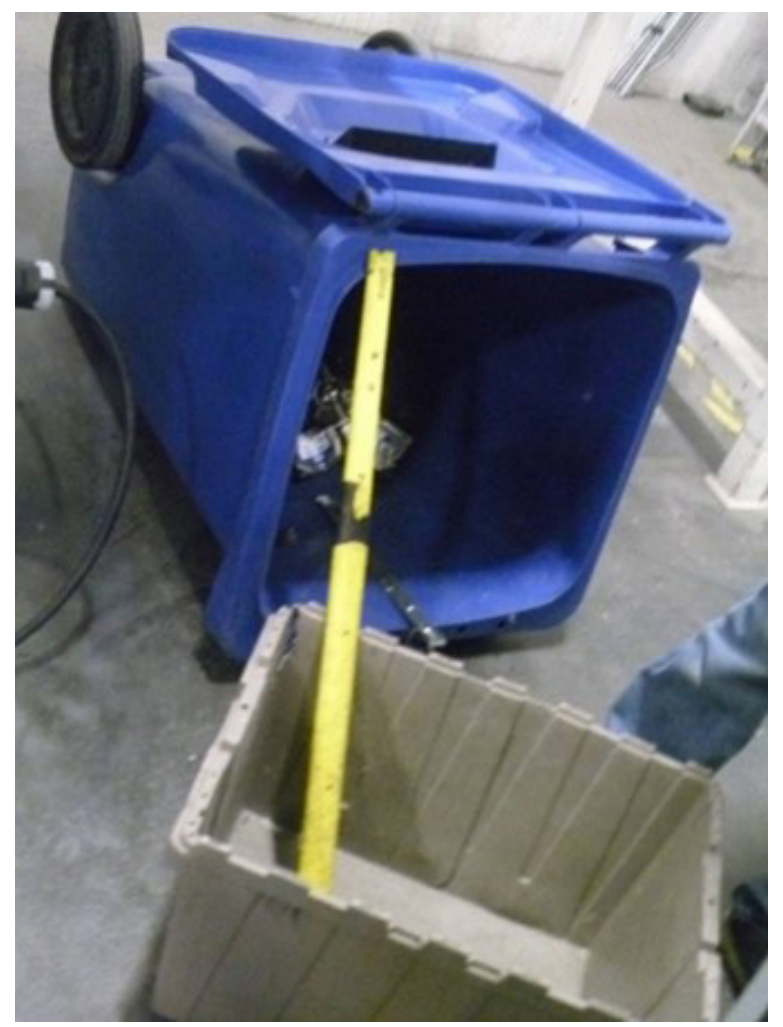

Figure 4. Small tote and 50-gallon tote on the floor with long handled tool used to pull hard drives out of the bottom of a large tote. Photo by NIOSH.

Employees manually inserted hard drives one at a time through a small port into the shredder. During this task, we observed employees facing the shredder, twisting toward the smaller tote, grabbing two hard drives, and then twisting back to load each hard drive into the shredder. The entry port for loading the hard drives into the shredder was above shoulder height so employees needed to reach above their shoulder to insert hard drives into the shredder (Figure 5). 


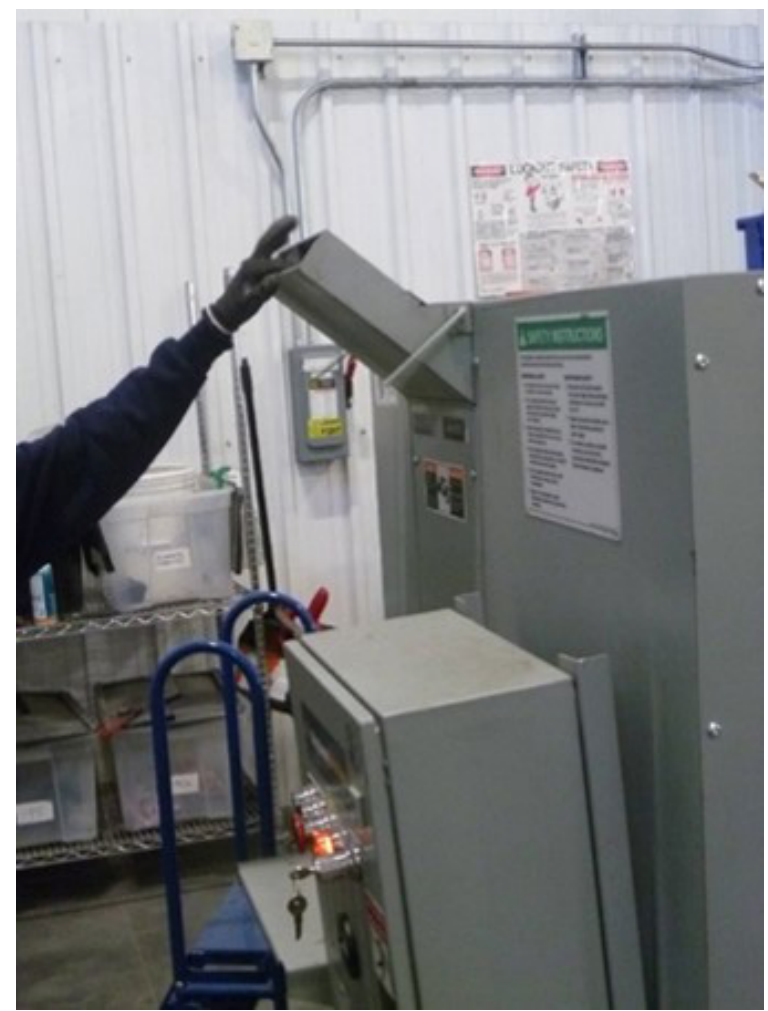

Figure 5. Employee reaching above shoulder height to insert hard drives into the small shredder. Photo by NIOSH.

Anti-fatigue mats were available at each disassembly station and in the refurbishing area. Some older mats had frayed edges (Figure 6). Each workstation had an overhead light; however, some employees reported that the lighting was too bright, so they elected not to use them. Some employees worked with their heads tilted forward, so they could better see their work. In addition, some drills had small lights incorporated into the drill near the drill bit to provide task lighting when removing small screws. Most workstations had toolboxes with magnets attached to hold tools. Some toolboxes were mounted on a height-adjustable rolling workstation, so they could be moved up and down depending on the needs of the employee (Figure 7). Drills were suspended from an adjustable retractor system so that employees did not need to hold the entire weight of the drill while using it. We observed that screw heads were often stripped. As a result, employees had to apply a large amount of force to the back of the drill in order to remove the screw. Screws and metal parts were often loose on the floor, and employees used a broom to sweep up metal parts. Lastly, although the height of the workstations was adjustable, employees had to call the maintenance department to adjust them. Instead of calling maintenance, the employees' solution was to have some workstations set higher and some lower. 


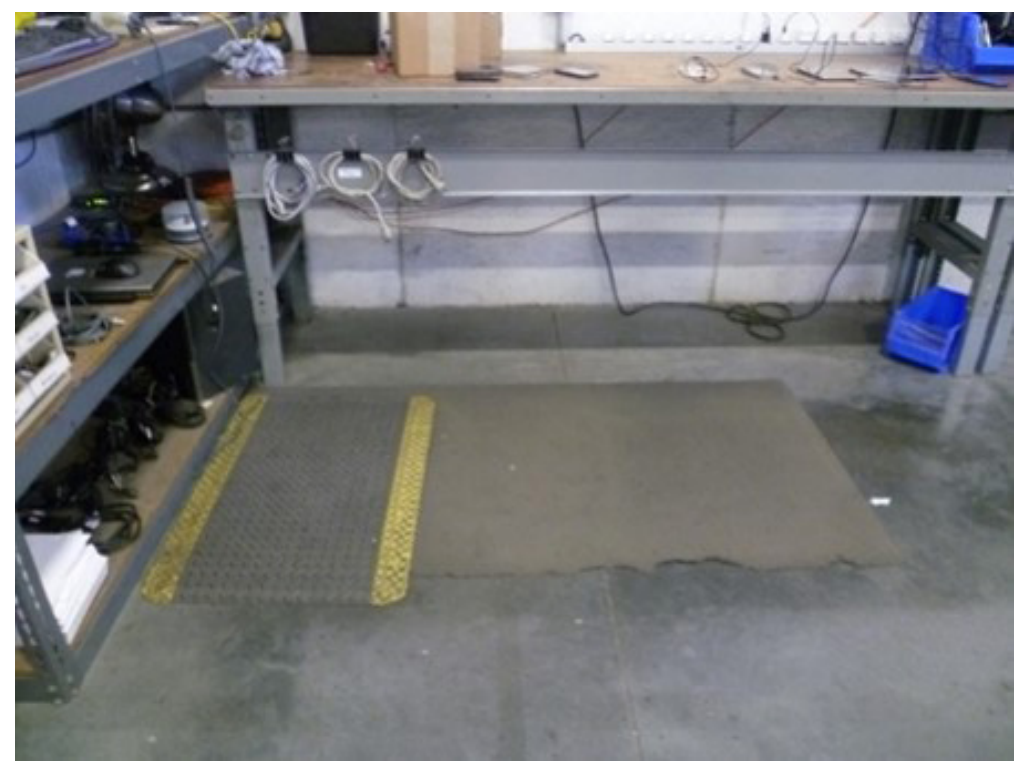

Figure 6. Anti-fatigue mat in the disassembly area with damaged front edge. Photo by $\mathrm{NIOSH}$.

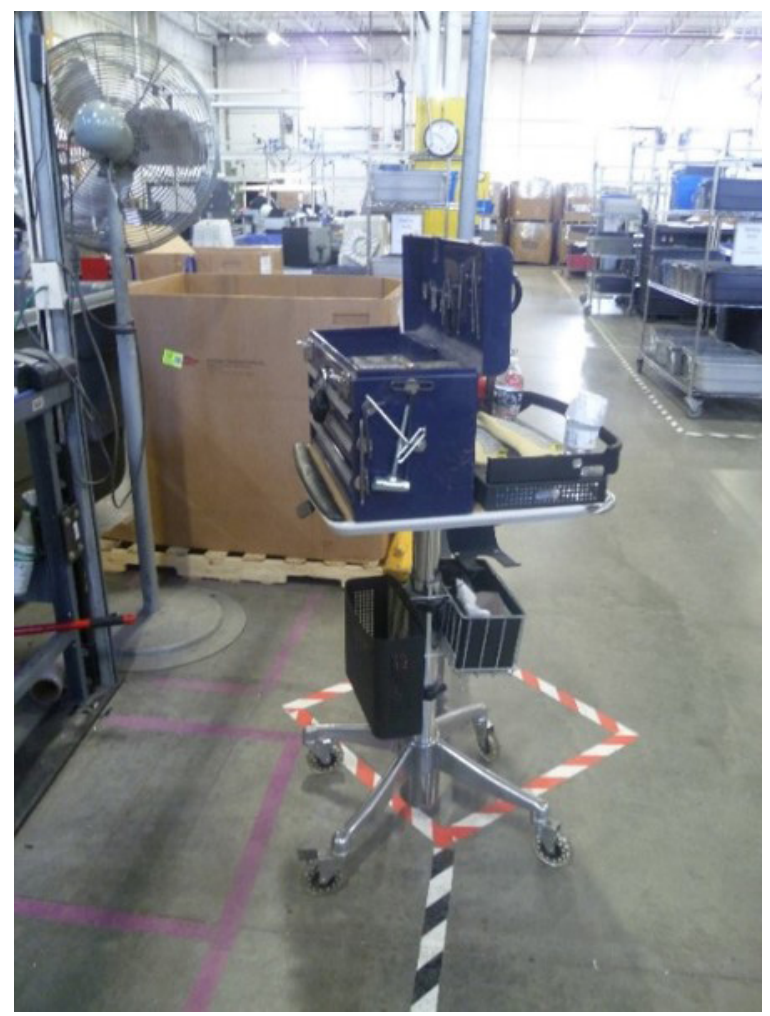

Figure 7. Toolbox mounted onto a height-adjustable rolling workstation. Photo by NIOSH. 
Employees in the refurbishing stations intermittently used keyboards that were hung almost perpendicular to the floor. We observed that many employees attempted a traditional typing posture while using the keyboard. As a result, employees extended their wrists further than 45 degrees to accommodate the angle of the keyboard (Figure 8). We also observed monitors of varying heights and viewing distances in the refurbishing stations.

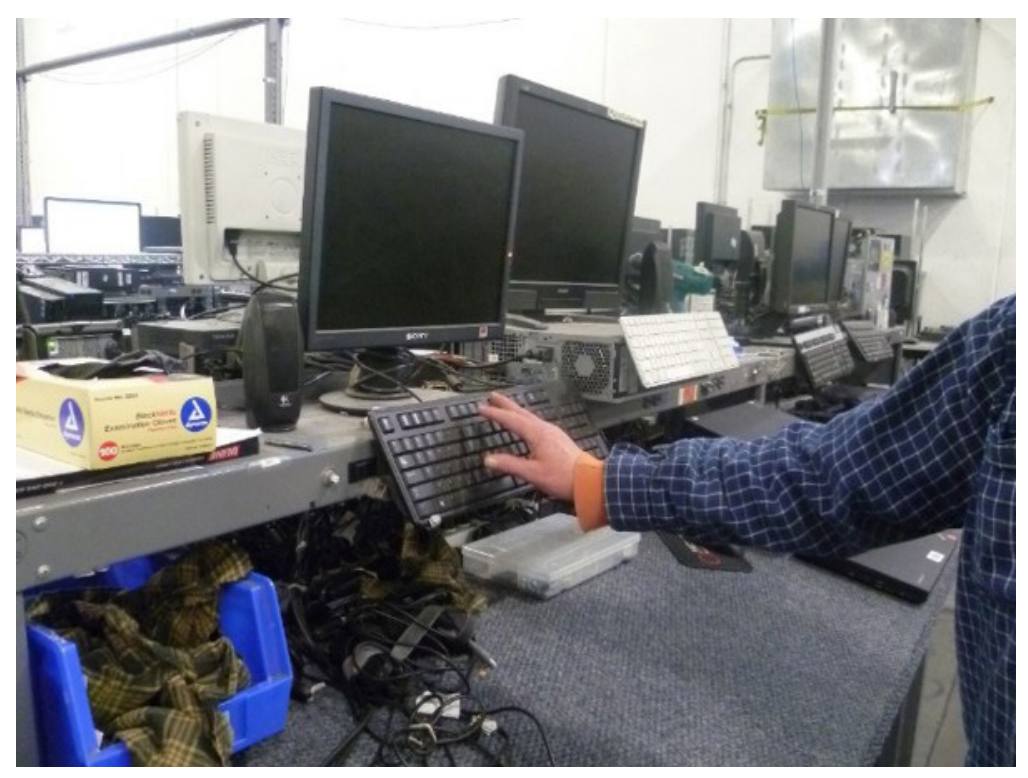

Figure 8. Keyboards mounted nearly vertically to a workstation in the refurbishing area. Photo by NIOSH.

\section{Noise Measurements}

We measured peak noise levels near the metal trash compactor, the baler, and the shredder. Sound levels near the metal trash compactor peaked at 123 decibels $(\mathrm{dB})$ when scrap metal was dumped into a metal container. Employees were not permitted to be in the metal bay while metal items were being dumped into the trash compactor. Employees stood directly outside the bay and wore ear muffs to protect their hearing while metal was being dumped. While the baler was operating, peak sound levels reached $119 \mathrm{~dB}$. The baler used an inclined conveyor belt which dumped plastic material, such as computer housings, into a compactor. Employees could pass through this area while plastics are being dumped into the compactor and subsequently baled. Hearing protection was not required in this location. Peak sound levels near the shredder reached $117 \mathrm{~dB}$ while an employee shredded hard drives. The employee operating the shredder wore foam insert ear plugs.

\section{Discussion}

\section{Metals}

The metals sampling results indicate that metals exposures are well controlled. However, practices such as dry sweeping could potentially re-aersolize dusts that may contain metals such as lead, unnecessarily exposing the employees to the hazard. The surface wipe results 
indicate well-cleaned and maintained processing surfaces and little to no metal migration or transfer outside of the processing areas. The hand wipe sample results indicate that some dermal exposure to lead may be occurring and that utilizing a lead-removing product to wash hands after work will be beneficial in reducing lead and other metals levels on the hands. NIOSH research shows that washing hands with soap and water alone is not completely effective in removing lead and other toxic metals from the skin [Esswein et al. 2011; NIOSH 2014 b,c]. Some commercially available lead removal products have been proven to remove more contamination from the skin. In addition, employees frequently reused gloves, which could potentially transfer contamination from the dirty gloves to the hands. Metals present on skin or clothing when leaving work could contaminate personal vehicles and homes and present a hazard to family members.

BLLs and blood cadmium levels were all below reference levels, and indicate that environmental lead and cadmium exposures were minimal and well controlled. Blood lead and cadmium levels were highest in disassembly workers, indicating that disassembly work is a potential source of lead exposure. Out of an abundance of caution, and because the waste stream in this industry is highly variable, frequent BLLs (every 6 months) in combination with good industrial hygiene practices (i.e., additional air sampling when a change in process occurs) is prudent. Employees in all other departments had BLLs similar to those seen in the general population. We did not find indium in the blood samples.

\section{Flame Retardants}

\section{Hand Wipes and Dermal Exposure}

Exposure to flame retardants in indoor non-work environments is thought to primarily occur from hand-to-mouth ingestion of dust and secondarily by absorption through the skin [Abdallah et al. 2015; Mäkinen et al. 2009]. These exposure pathways can also occur in workplaces.

The use of OctaBDE flame retardants in electronics was phased out after 2004. The congeners for OctaBDE (BDE-183, BDE-154, and BDE-153) were only detected in a low percentage of the wipes (23\% of the postshift handwipes, overall) which suggests that at the time of our evaluation, the company was not processing or processing very few electronics made before 2004. We detected BDE-209, TPHP, TCP, BTBPE, DBDPE, TBBPA, BEH-TEBP, and TCIPP in higher median levels postshift than preshift. BDE-209, TPHP, TCP, BTBPE, DBDPE, and TBBPA are commonly used in electronics now and in the past and therefore the higher postshift value is not unexpected. Additionally, the GM levels of BDE-209 on employees' hands were substantially higher than found in the general population; whereas, TPHP levels were approximately equal to or slightly less than the general population (Table 11). EH-TBB, BEH-TEBP, and TCIPP are less commonly used in electronics; however their presence is not completely unexpected. When compared to the general population, our TCIPP GM postshift levels in the hand wipes were higher.

TDCIPP and PentaBDE are typically found in polyurethane foam, not in electronics and were phased out starting in 2005 [Alaee et al. 2003]. Results for PentaBDE congeners (BDE-99 and BDE-47) were either not detected or detected with a maximum median of $15 \mathrm{ng} / \mathrm{sample}$. We saw very little difference between the pre and postshift levels for these 
flame retardants. Additionally, the detectable levels of TDCIPP were slightly higher in the office handwipes samples, but within the same order of magnitude. Even though PentaBDE and TDCIPP are not typically used in electronics, they are often present in high concentration in office dusts, which could collect inside electronics [Sjödin et al. 2008; Watkins et al. 2013]. In addition, the preshift and postshift GM values for these flame retardants are similar to the levels reported in the general population, suggesting minimal dermal exposure to these flame retardants at work.

Table 11 shows the levels of selected flame retardants on hands of the electronics recycling employees compared to results published in studies of the general population, which were collected using similar hand wipe methods. The preshift GM levels for the flame retardants were approximately equal to the general population. However, for some flame retardants we found higher postshift levels on employees' hands which shows evidence of workplace exposure and highlights the importance of PPE use and hand washing to reduce exposures. Thorough hand washing at the end of the work shift with soap and water should remove contaminants from the skin to reduce risk of possible ingestion through hand-to-mouth contact and continued dermal exposure. However, contaminants remaining on the skin could be transferred to non-work surfaces in vehicles and in the home. A study of flame retardant exposure in young children suggested those who washed their hands at least five times a day had lower levels of flame retardants on their hands than those who washed less often [Stapleton et al. 2014]. Office workers who washed their hands fewer than four times daily had significantly higher levels of PentaBDE on their hand wipes than those who washed four or more times daily [Watkins et al. 2011]. Absorption of TCIPP and TCEP was significantly reduced by hand washing in an experimental study using human ex vivo skin, but penetration continued, presumably from the reservoir in the skin [Abdallah et al. 2016]. Hand washing did not significantly reduce absorption of TDCIPP [Abdallah et al. 2016]. 
Table 11. Geometric mean and range of flame retardants on hand wipes in electronics recycling participants, the disassembly employees, and the general population, in ng/sample

\begin{tabular}{|c|c|c|c|c|c|c|c|}
\hline \multirow[t]{2}{*}{$\begin{array}{l}\text { Flame } \\
\text { retardant }\end{array}$} & \multicolumn{2}{|c|}{$\begin{array}{c}\text { Electronics recycling } \\
\text { employees }(\mathrm{n}=37-38) \\
\% \text { Detected } \\
\text { GM } \\
\text { range }\end{array}$} & \multicolumn{2}{|c|}{$\begin{array}{c}\text { Disassembly } \\
\text { employees }(n=16) \\
\% \text { Detected } \\
\text { GM } \\
\text { range }\end{array}$} & \multirow{2}{*}{$\begin{array}{c}\text { General } \\
\text { population* } \\
n=53 \\
\% \text { Detected } \\
\text { GM } \\
\text { range }\end{array}$} & \multirow{2}{*}{$\begin{array}{c}\text { General } \\
\text { population† } \\
\mathrm{n}=33 \\
\% \text { Detected } \\
\mathrm{GM} \\
\text { range }\end{array}$} & \multirow{2}{*}{$\begin{array}{c}\text { General } \\
\text { population } \ddagger \\
n=40 \\
\% \text { Detected } \\
\text { GM } \\
\text { range }\end{array}$} \\
\hline & Preshift & Postshift & Preshift & Postshift & & & \\
\hline \multicolumn{8}{|c|}{ OctaBDE (commonly used in electronics until around 2004) } \\
\hline BDE-183 & $\begin{array}{c}5 \% \\
\text { N/A } \\
\text { ND-22 }\end{array}$ & $\begin{array}{c}21 \% \\
\text { N/A } \\
\text { ND-140 }\end{array}$ & $\begin{array}{c}13 \% \\
N / A \\
N D-22\end{array}$ & $\begin{array}{c}38 \% \\
\text { N/A } \\
\text { ND-137 }\end{array}$ & $\begin{array}{c}\text { Not } \\
\text { sampled }\end{array}$ & $\begin{array}{c}76 \% \\
0.7 \\
\text { ND-8.5 }\end{array}$ & $\begin{array}{c}\text { Not } \\
\text { sampled }\end{array}$ \\
\hline BDE-154 & $\begin{array}{c}3 \% \\
\text { N/A } \\
\text { ND-45 }\end{array}$ & $\begin{array}{l}0 \% \\
\text { N/A }\end{array}$ & $\begin{array}{c}6 \% \\
\text { N/A } \\
\text { ND-45 }\end{array}$ & 0 & $\begin{array}{c}87 \% \\
1.0 \\
\text { ND-59.8 }\end{array}$ & $\begin{array}{c}97 \% \\
4.9 \\
\text { ND-59 }\end{array}$ & $\begin{array}{c}\text { Not } \\
\text { sampled }\end{array}$ \\
\hline BDE-153 & $\begin{array}{c}5 \% \\
\text { N/A } \\
\text { ND-29 }\end{array}$ & $\begin{array}{c}3 \% \\
\text { N/A } \\
\text { ND-16 }\end{array}$ & $\begin{array}{c}13 \% \\
\text { N/A } \\
\text { ND-29 }\end{array}$ & $\begin{array}{c}6 \% \\
\text { N/A } \\
\text { ND-16 }\end{array}$ & $\begin{array}{c}91 \% \\
1.3 \\
\text { ND-67.9 }\end{array}$ & $\begin{array}{c}97 \% \\
15.8 \\
\text { ND-290 }\end{array}$ & $\begin{array}{c}\text { Not } \\
\text { sampled }\end{array}$ \\
\hline \multicolumn{8}{|c|}{ OctaBDE and DecaBDE (commonly used in electronics until around 2013) } \\
\hline BDE-209 & $\begin{array}{c}92 \% \\
39 \\
\text { ND-166 }\end{array}$ & $\begin{array}{c}100 \% \\
160 \\
11-1,032\end{array}$ & $\begin{array}{c}94 \% \\
44 \\
\text { ND-166 }\end{array}$ & $\begin{array}{c}100 \% \\
285 \\
36-1,032\end{array}$ & $\begin{array}{c}96 \% \\
19.5 \\
\text { ND-804 }\end{array}$ & $\begin{array}{c}67 \% \\
43.1 \\
\text { ND-270 }\end{array}$ & $\begin{array}{c}\text { Not } \\
\text { sampled }\end{array}$ \\
\hline \multicolumn{8}{|c|}{ Commonly used in electronics now and in the past } \\
\hline TPHP & $\begin{array}{c}70 \% \\
20 \\
\text { ND-164 }\end{array}$ & $\begin{array}{c}68 \% \\
36 \\
\text { ND-3,064 }\end{array}$ & $\begin{array}{c}75 \% \\
28 \\
\text { ND-154 }\end{array}$ & $\begin{array}{c}63 \% \\
31 \\
\text { ND-198 }\end{array}$ & $\begin{array}{c}87 \% \\
62.1 \\
\text { ND-1,230 }\end{array}$ & $\begin{array}{c}\text { Not } \\
\text { sampled }\end{array}$ & $\begin{array}{c}100 \% \\
22.4 \\
?-416.7\end{array}$ \\
\hline \multicolumn{8}{|c|}{ Less commonly used in electronics now and in the past } \\
\hline TCIPP & $\begin{array}{c}63 \% \\
51 \\
\text { ND-2,226 }\end{array}$ & $\begin{array}{c}95 \% \\
180 \\
\text { ND-3,097 }\end{array}$ & $\begin{array}{c}75 \% \\
73 \\
\text { ND-2,226 }\end{array}$ & $\begin{array}{c}94 \% \\
125 \\
\text { ND-1,362 }\end{array}$ & $\begin{array}{c}\text { Not } \\
\text { sampled }\end{array}$ & $\begin{array}{c}\text { Not } \\
\text { sampled }\end{array}$ & $\begin{array}{c}100 \% \\
45.4 \\
?-255\end{array}$ \\
\hline \multicolumn{8}{|c|}{ Rarely used in electronics } \\
\hline \multicolumn{8}{|l|}{ PentaBDE } \\
\hline BDE-99 & $\begin{array}{c}74 \% \\
17 \\
\text { ND-405 }\end{array}$ & $\begin{array}{c}76 \% \\
17 \\
\text { ND-99 }\end{array}$ & $\begin{array}{c}75 \% \\
16 \\
\text { ND-405 }\end{array}$ & $\begin{array}{c}69 \% \\
14 \\
\text { ND-75 }\end{array}$ & $\begin{array}{c}100 \% \\
26 \\
4.4-707\end{array}$ & $\begin{array}{c}100 \% \\
72.2 \\
0.9-747\end{array}$ & $\begin{array}{c}\text { Not } \\
\text { sampled }\end{array}$ \\
\hline BDE-47 & $\begin{array}{c}71 \% \\
16 \\
\text { ND-207 }\end{array}$ & $\begin{array}{c}68 \% \\
14 \\
\text { ND-107 }\end{array}$ & $\begin{array}{c}81 \% \\
15 \\
\text { ND-198 }\end{array}$ & $\begin{array}{c}56 \% \\
11 \\
\text { ND-33 }\end{array}$ & $\begin{array}{c}100 \% \\
18.4 \\
2.5-454\end{array}$ & $\begin{array}{c}97 \% \\
72.7 \\
\text { ND-565 }\end{array}$ & $\begin{array}{c}\text { Not } \\
\text { sampled }\end{array}$ \\
\hline $\begin{array}{l}\text { BDE- } \\
100\end{array}$ & $\begin{array}{c}16 \% \\
\text { N/A } \\
\text { ND-56 }\end{array}$ & $\begin{array}{c}18 \% \\
\text { N/A } \\
\text { ND-22 }\end{array}$ & $\begin{array}{c}25 \% \\
\text { N/A } \\
\text { ND-56 }\end{array}$ & $\begin{array}{c}19 \% \\
\text { N/A } \\
\text { ND-19 }\end{array}$ & $\begin{array}{c}81 \% \\
2.8 \\
\text { ND-128 }\end{array}$ & $\begin{array}{c}100 \% \\
13.3 \\
0.08-142\end{array}$ & $\begin{array}{c}\text { Not } \\
\text { sampled }\end{array}$ \\
\hline TDCIPP & $\begin{array}{c}97 \% \\
163 \\
\text { ND-1,755 }\end{array}$ & $\begin{array}{c}92 \% \\
128 \\
\text { ND-1,781 }\end{array}$ & $\begin{array}{c}100 \% \\
207 \\
71-662\end{array}$ & $\begin{array}{c}88 \% \\
103 \\
\text { ND-555 }\end{array}$ & $\begin{array}{c}91 \% \\
84.1 \\
\text { ND-537 }\end{array}$ & $\begin{array}{c}\text { Not } \\
\text { sampled }\end{array}$ & $\begin{array}{c}95 \% \\
108.3 \\
\text { ND-535 }\end{array}$ \\
\hline
\end{tabular}

? = Study did not provide a lower-end of the range

*Hoffman et al. 2015

†Stapleton and Dodder 2008

‡Hammel et al. 2016 
Several factors can affect overall interpretation of the hand wipe sampling results. The hand wipe sampling procedure removes an unknown proportion of the flame retardants that are present on the hand and the proportion removed can vary depending on the technique of the person doing the wiping. In a pilot hand wipe study we previously conducted, the amount removed by the first gauze wipe set varied from $0 \%$ to $98 \%$ of the total [Beaucham et al. 2018]. If a hand wipe removed more of a particular flame retardant preshift than was added to the hands during the shift, it could appear there was a decline in flame retardant levels, even though exposure to that flame retardant may have occurred during the work shift.

We do not know the efficiency of hand washing in removing different flame retardants. If hand washing was very efficient in removing flame retardants from the employees' hands, then the postshift flame retardant levels might be far less than if hand washing had not been done during the work shift. Participants with less time between their last hand washing and their postshift hand wipe sample might lower amounts of flame retardants on their hands due to removal from washing. We instructed participants to wash their hands as they normally would during the work shift, but instructed them to refrain from washing them immediately before having their postshift hand wipe sampling done. We did not record the time interval from the last hand washing to the postshift wipe sampling. The wide variability of the results could be from interpersonal sampling variation, such as participants wiping their hands differently, thereby removing the flame retardants from a previously unwiped portion of the hand or differences in applied pressure and speed of wiping. We do not know if differences in skin moisture and use of skin care products could affect the results.

The surface wipe samples we collected help us identify which part or parts of the work area are contributing to the flame retardants in the air samples and hand wipe samples. In this facility, the triage table and the disassembly workstations had the highest concentrations of flame retardants, and the widest variety of flame retardants. Similarly, the disassembly employees had the highest median concentrations in their air samples and the highest levels of flame retardants commonly found in electronics. The resale area below the packing material delivery system was primarily TCP and a small amount of TCIPP. The presence of TCP was most likely because the foam that is used in their packaging process typically contains TCP. Interestingly, $\gamma-\mathrm{HBCD}$ was found on one of the disassembly workstations. Correspondingly, it was found in the postshift handwipes of 9 of the 16 of the disassembly employees, but in none of their preshift handwipes. This indicates that although they are likely being exposed to $\gamma$-HBCD while disassembling electronics, it is probably washed off of the hands using soap and water.

\section{Personal Air Sampling for Flame Retardants}

Several published studies have examined airborne exposure to flame retardants in homes and nonindustrial settings. Allen et al. [2007] collected inhalable personal air samples for PBDEs from 20 individuals in Boston for 7 days while they were at home. The main congeners they detected were BDE-47, BDE-209, and BDE-99. BDE-47 was detected in $100 \%$ of the air samples with a GM concentration of $0.227 \mathrm{ng} / \mathrm{m}^{3}$. BDE-209 was detected in $45 \%$ of the samples with a GM concentration of $0.174 \mathrm{ng} / \mathrm{m}^{3}$. The authors estimated that about $22 \%$ of the participants' total BDE-209 exposures were likely through inhalation. 
La Guardia and Hale [2015] evaluated flame retardant exposures on four individuals in their homes in Seattle. Samples were collected for an 8-hour period. Inhalable personal air sampling found that the predominant flame retardants were TDCIPP (94\% of the total) and TCIPP ( $65 \%$ of the total). BDE-209 was detected in two of the four samples, at concentrations of $0.1 \mathrm{ng} / \mathrm{m}^{3}$ and $3.8 \mathrm{ng} / \mathrm{m}^{3}$. Schreder et al. [2016] collected personal air samples for chlorinated organophosphate flame retardants over a 24-hour period, on 10 individuals in Washington. The median concentrations were $262 \mathrm{ng} / \mathrm{m}^{3}$ (TCIPP), $82 \mathrm{ng} / \mathrm{m}^{3}$ (TDCIPP) and $78 \mathrm{ng} / \mathrm{m}^{3}$ (TCEP).

Swedish researchers examined the presence and levels of several organophosphate flame retardants using area air sampling for particulate and vapor at night in three schools, a day care center, and an office. TPHP was detected in all locations, but below levels of quantification in two, and at concentrations less than $1 \mathrm{ng} / \mathrm{m}^{3}$ in the others [Carlsson et al. 1997]. The highest concentrations these researchers measured were for TCEP, with mean concentrations in each building ranging from $11 \mathrm{ng} / \mathrm{m}^{3}$ to $250 \mathrm{ng} / \mathrm{m}^{3}$. These researchers also detected TCIPP in much lower concentrations (maximum mean concentration $41 \mathrm{ng} / \mathrm{m}^{3}$ ).

We anticipated that occupational exposures to flame retardants in the air would differ from air sampling results in non-industrial environments. Our evaluation demonstrated airborne exposures to several flame retardants, primarily TCIPP, TCP, BDE-209 and TPHP.

TCIPP is not typically used in electronics and is predominantly found in polyurethane foam [Alaee et al. 2003; Stapleton et al. 2011; van der Veen and Boer 2012]. We suspect the source of TCIPP to be primarily from dust collected inside of the electronic equipment (Figure 9). Personal air sampling GM concentrations of BDE-209, measured in Swedish electronics recycling disassemblers over a 2-year period were $25 \mathrm{ng} / \mathrm{m}^{3}$ [Pettersson-Julander et al. 2004]. The GM air concentration of general air samples in another Swedish electronics recycling company was $0.22 \mathrm{ng} / \mathrm{m}^{3}$ [Sjodin et al. 2001]. We could not compare our BDE-209 results to these studies because we did not calculate GM values for BDE-209 because only $61 \%$ of the samples were detected.

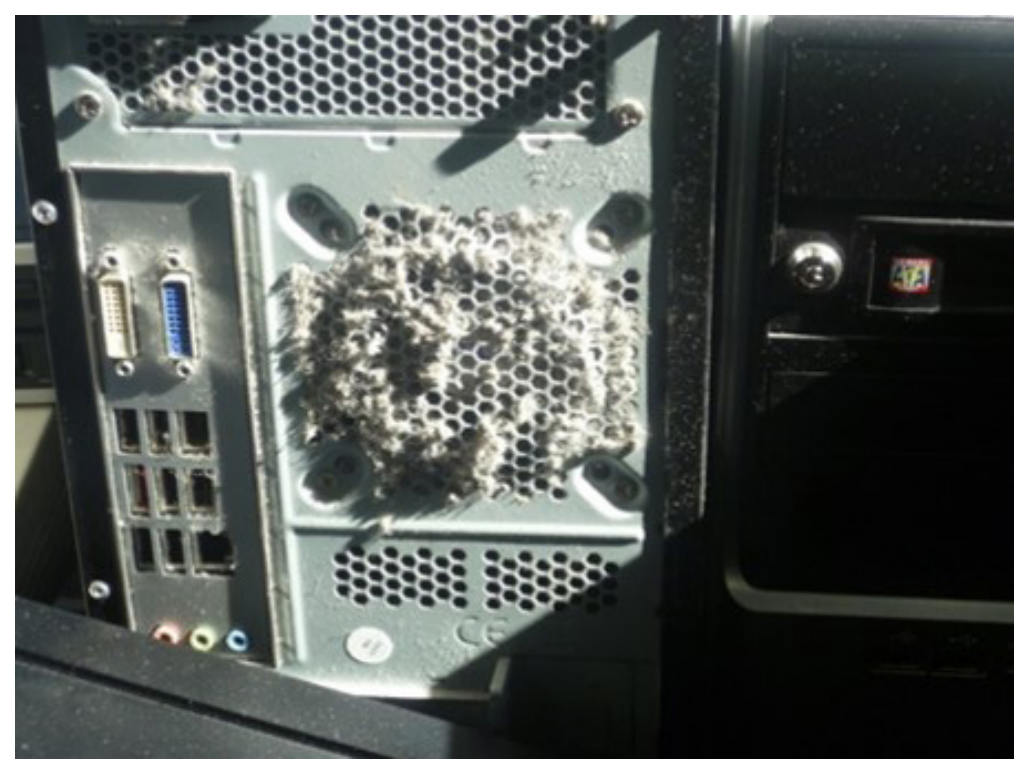

Figure 9. Cooling fan intake on a piece of electronic equipment shows that has pulled in dust from the environment. Photo by NIOSH. 
TDCIPP, TCEP, and PentaBDE are not typically used in electronics, but are predominantly found in polyurethane foam [Alaee et al. 2003; Stapleton et al. 2011; van der Veen and Boer 2012]. We detected some TDCIPP, and congeners of PentaBDE. We only detected TCEP in $18 \%$ of the samples. We suspect the source of PentaBDE to be primarily from dust inside of the electronic equipment (range ND-10 ng/ $\mathrm{m}^{3}$ ). In contrast to our results, studies from non-industrial settings [La Guardia and Hale 2015; Schreder et al. 2016] detected far higher concentrations of TCIPP and TDCIPP.

A study of sorters and disassemblers (not shredders) at two electronics recycling facilities in Finland documented a maximum airborne DBDPE concentration of $360 \mathrm{ng} / \mathrm{m}^{3}$ and median sum PBDE concentrations of $295 \mathrm{ng} / \mathrm{m}^{3}$ [Rosenberg et al. 2011]. The researchers recommended ventilation controls then resampled after their installation. Median airborne DBDPE concentrations decreased to $14 \mathrm{ng} / \mathrm{m}^{3}$, and median PBDE concentrations dropped to $65 \mathrm{ng} / \mathrm{m}^{3}$, indicating that controls reduced exposures. Our DBDPE results showed a maximum of $84 \mathrm{ng} / \mathrm{m}^{3}$ and only $29 \%$ detected. These levels were lower than those reported by Rosenberg [2011].

TPHP has been used as a flame retardant in electronic products as well as a plasticizer [van der Veen and Boer 2012]. We found TPHP in the third highest concentration in our air samples, with a GM concentration of $7.3 \mathrm{ng} / \mathrm{m}^{3}$. A study of two other electronics recycling facilities in Finland where sorting, dismantling, and crushing were performed showed TPHP was present in the highest airborne concentrations of the eight organophosphate flame retardants measured (GM personal air concentrations of TPHP of $760 \mathrm{ng} / \mathrm{m}^{3}$ and $850 \mathrm{ng} / \mathrm{m}^{3}$ ) [Mäkinen et al. 2009]. Our TPHP air concentrations were far less than either of our comparison studies.

Mäkinen et al. [2009] also found that airborne TCP was typical in electronics dismantling facilities. The GM personal air TCP concentration in a dismantling and sorting room of an electronics dismantling company was $90 \mathrm{ng} / \mathrm{m}^{3}$ (range: $62 \mathrm{ng} / \mathrm{m}^{3}-175 \mathrm{ng} / \mathrm{m}^{3}$ ) and $110 \mathrm{ng} / \mathrm{m}^{3}$ (range: $62 \mathrm{ng} / \mathrm{m}^{3}-175 \mathrm{ng} / \mathrm{m}^{3}$ ) in an electronics crushing process at a separate facility. Our recycling participants had a GM exposure of $8.8 \mathrm{ng} / \mathrm{m}^{3}\left(\right.$ range ND-71 ng/m $/ \mathrm{m}^{3}$ ), which is lower than the comparison studies.

Mäkinen et al. [2009] detected TBBPA in few air samples and at very low concentrations. Sjodin et al. [2001] found TBBPA present in air with a mean concentration of $0.20 \mathrm{ng} / \mathrm{m}^{3}$, and Rosenberg et al. [2011] found TBBPA with a median concentration of $145 \mathrm{ng} / \mathrm{m}^{3}$. We detected TBBPA in the air in $63 \%$ of samples, with a maximum concentration of $63 \mathrm{ng} / \mathrm{m}^{3}$. TBBPA is one of the most commonly used brominated flame retardants in printed circuit boards. Unlike most of the flame retardants we examined, which are additive flame retardants (blended with the plastics), TBBPA is a reactive flame retardant (chemically bonded into the plastics). Because of this chemical bonding, we found very little in our air samples, as expected [Rosenberg et al. 2011]. It is unclear why TBBPA was detected in higher concentrations in previous studies.

BTBPE is found in Firemaster 680, which is used in many computer housings. PetterssonJulander et al. [2004] found a GM concentration of airborne BTBPE of $15 \mathrm{ng} / \mathrm{m}^{3}$. We measured similar but slightly lower concentrations with $18 \%$ detected and a maximum of $15 \mathrm{ng} / \mathrm{m}^{3}$. 
These data indicate that airborne exposure in this electronics recycling company differ from those in homes and nonindustrial settings, but are within the range of exposures found in other electronic recycling facilities. In addition, this facility did not do a substantial amount of mechanical disassembly, which typically aerosolizes more of the flame retardants [NIOSH 2018a].

\section{Biological Burden of Flame Retardants: Blood}

We examined serum PBDE concentrations and compared them to a representative sample of the general population. The GM serum concentration of BDE-209 was $2.95 \mathrm{ng} / \mathrm{g}$ lipid weight. NHANES data did not have reported values because so many of their samples were below the LOD of $5.8 \mathrm{ng} / \mathrm{g}$ lipid weight. In addition to diet, occupational exposures may have contributed to serum BDE concentrations in our participants. The NHANES samples were collected in 2007 and 2008, when concentrations were presumably higher because this was prior to the phase-out of DecaBDE. Data is also now available for the years 2009 and 2010, but it is segregated by age groups, gender, and race/ethnicity [CDC 2018]. Swedish electronics disassembly employees had a median serum BDE-209 concentration of $4.8 \mathrm{ng} / \mathrm{g}$ lipid weight [Thuresson et al. 2006a]. Workers were retested several years later after the shredder was moved from the disassembly area to a different location. The median decrease in their serum BDE-209 concentrations was 46\% [Thuresson et al. 2006b]. In the initial Swedish study, serum concentrations of BDE-47, BDE-153, BDE-154, and BDE-183 were also significantly higher than their reference populations of computer clerks and hospital cleaners [Sjodin et al. 1999]. We found median serum concentrations of BDE-153 similar to that of the general population sample. Concentrations of other PBDEs, PCBs, and other persistent pollutants were generally lower in our participants than in NHANES participants. Similar to BDE levels, this may be because the NHANES specimens were collected several years before ours when concentrations were likely higher. In addition, PCB-153 concentrations in our participants were lower than in the NHANES specimens. PCB-153 is a stable, persistent contaminant, and exposure to it comes mainly from food [Jakobsson et al. 2002].

\section{Biological Burden of Flame Retardants: Urine}

Biomonitoring for phosphate flame retardants is in its early phase and identification of major metabolites and pharmacokinetics are not fully known [Dodson et al. 2014; Kosarac et al. 2016]. However, half-lives of identified flame retardant metabolites appear to be relatively short (hours); therefore, results of urine measurements likely reflect recent exposures [Carignan et al. 2016; Dodson et al. 2014; Hammel et al. 2016; Meeker et al. 2013a]. NHANES has recently released urinary metabolite data for the general population for the years 2013 and 2014 [CDC 2018].

Median uncorrected urinary concentrations of DPHP (a metabolite of TPHP, used in plastic housings of electronics, among other things) declined slightly across the shift in disassembly, refurbishing, and office participants during our visit and stayed about the same in participants who performed mainly resale work. However, when we evaluated the creatinine corrected values, only refurbishing measurements declined. All other departments had similar preshift and postshift values. Table 12 contains results of urine testing for flame retardant metabolites 
from published studies in the general population. GM uncorrected postshift concentrations (range: $0.12-0.61 \mu \mathrm{g} / \mathrm{L}$ ) were lower than those reported in the U.S. general population, which ranged from $1.1 \mu \mathrm{g} / \mathrm{L}$ to $1.9 \mu \mathrm{g} / \mathrm{L}$.

A study of gymnasts before and after a 2.5 hour practice demonstrated that GM DPHP concentrations nearly doubled (from 6 to $11 \mu \mathrm{g} / \mathrm{L}$ ), and then began to decline between 1 and 3 hours after practice [Carignan et al. 2016]. In addition to its use in electronics products, TPHP is a component of Firemaster 550 (and other flame retardant mixtures), which is used in polyurethane foam. Gymnasts use pits filled with foam blocks and other foam padded equipment to protect them from injury when falling. These levels in gymnasts were much higher than those we found (GM range: ND $[<0.16]-2.4 \mu \mathrm{g} / \mathrm{L})$.

A study of the relationship between reproductive outcomes in 33 men found a $57 \%$ decrease in sperm concentration, a 19\% decrease in straight line velocity, a $13 \%$ decrease in linearity, and a 38\% decrease in inhibin B concentrations in blood for each interquartile increase in urinary DPHP [Meeker et al. 2013a]. Specific gravity corrected urinary DPHP ranged from nondetectable $(<0.06 \mu \mathrm{g} / \mathrm{L}$ ) to 9.84 (median $0.27 \mu \mathrm{g} / \mathrm{L}, 95$ th percentile $2.65 \mu \mathrm{g} / \mathrm{L}$ ) in the study from which these men were a subset [Meeker et al. 2013b]. Another study found a significant $0.43 \mu \mathrm{g} / \mathrm{dL}$ increase in mean total $\mathrm{T} 4$ serum concentrations in individuals with specific gravity corrected urine DPHP concentrations greater than or equal to $2.65 \mu \mathrm{g} / \mathrm{L}$ compared to those with concentrations below $2.65 \mu \mathrm{g} / \mathrm{L}$ [Preston et al. 2017].

TPHP was present in the air in our electronics recycling company in the third highest concentrations, after TCIPP and TCP. Median airborne concentrations of TPHP were highest among office participants. All groups of participants had increased median levels of TPHP on their hands postshift, but the difference between the preshift and postshift median levels were highest in disassembly and refurbishing participants. These findings in conjunction with urinary DPHP findings suggest that TPHP is present, but significant absorption was not occurring on the days sampled. 
Table 12. Uncorrected creatinine concentrations of urine flame retardant metabolites in the general population, in $\mu \mathrm{g} / \mathrm{L}$

\begin{tabular}{|c|c|c|c|c|c|}
\hline \multirow[t]{2}{*}{$\begin{array}{l}\text { Flame } \\
\text { retardant }\end{array}$} & \multicolumn{5}{|c|}{$\begin{array}{c}\text { General population } \\
\% \text { detected } \\
\text { GM } \\
\text { range }\end{array}$} \\
\hline & $N=9^{*}$ & $N=39 \dagger$ & $N=16 \ddagger$ & $N=13 \S$ & $\mathrm{N}=40 \pi$ \\
\hline \multicolumn{6}{|c|}{ Commonly used in electronics now and in the past } \\
\hline $\begin{array}{l}\text { DPHP } \\
\text { (parent } \\
\text { compound } \\
\text { TPHP) }\end{array}$ & $\begin{array}{c}100 \% \\
1.074 \\
0.29-7.44\end{array}$ & $\begin{array}{c}97 \% \\
1.9 \\
\text { ND }(<0.005)-37.3\end{array}$ & $\begin{array}{c}62 \% \\
1.1 \text { (mean) } \\
\text { ND }(<0.23)-6.8\end{array}$ & $\begin{array}{c}100 \% \\
1.5 \\
0.2-5.6\end{array}$ & $\begin{array}{c}100 \% \\
1.14 \\
* *-26.77\end{array}$ \\
\hline \multicolumn{6}{|c|}{ Less commonly used in electronics now and in the past } \\
\hline $\begin{array}{l}\text { BCIPP } \\
\text { (parent } \\
\text { compound } \\
\text { TCIPP) }\end{array}$ & Not sampled & Not sampled & $\begin{array}{c}31 \% \\
0.17 \text { (mean) } \\
\text { ND }(<0.06)-0.97\end{array}$ & $\begin{array}{c}92 \% \\
0.4 \\
0.04-3.5\end{array}$ & $\begin{array}{c}18 \% \\
\text { Not calculated } \\
* *-0.57\end{array}$ \\
\hline $\begin{array}{l}\text { BCEP } \\
\text { (parent } \\
\text { compound } \\
\text { TCEP) }\end{array}$ & Not sampled & Not sampled & $\begin{array}{c}75 \% \\
0.76(\text { mean }) \\
\text { ND }(<0.10)-2.1\end{array}$ & $\begin{array}{c}100 \% \\
3.4 \\
0.4-15.0\end{array}$ & Not sampled \\
\hline \multicolumn{6}{|c|}{ Rarely used in electronics } \\
\hline $\begin{array}{l}\text { BDCIPP } \\
\text { (parent } \\
\text { compound } \\
\text { TDCIPP) }\end{array}$ & $\begin{array}{c}100 \% \\
0.148 \\
0.05-1.66\end{array}$ & $\begin{array}{c}97 \% \\
1.3 \\
\text { ND }(<0.013)-19.9\end{array}$ & $\begin{array}{c}94 \% \\
0.46 \text { (mean) } \\
\text { ND }(<0.02)-3.9\end{array}$ & $\begin{array}{c}100 \% \\
2.5 \\
0.5-7.3\end{array}$ & $\begin{array}{c}100 \% \\
2.32 \\
* *-21.21\end{array}$ \\
\hline \multicolumn{6}{|c|}{${ }^{*}$ Cooper et al. 2011} \\
\hline \multicolumn{6}{|c|}{ †Hoffman et al. 2014} \\
\hline \multicolumn{6}{|c|}{ ‡Dodson et al. 2014} \\
\hline \multicolumn{6}{|c|}{ §Petropoulou et al. 2016} \\
\hline \multicolumn{6}{|c|}{ đHammel et al. 2016} \\
\hline ** Limit of $d \epsilon$ & ction not given & & & & \\
\hline
\end{tabular}

Urinary BDCIPP (a metabolite of TDCIPP, whose main use is in polyurethane foam) concentrations declined across the shift in our participants, despite relatively high hand levels of TDCIPP. The overall GM uncorrected postshift concentration was $0.546 \mu \mathrm{g} / \mathrm{L}$. They were slightly lower than those reported in the U.S. general population, which ranged from 1.3-2.5 $\mu \mathrm{g} / \mathrm{L}$ (Table 12). BDCIPP is specific to TDCIPP. TDCIPP was detected in the air, ranging from ND-44 ng/ $\mathrm{m}^{3}$. TDCIPP in dust has been detected at higher levels in vehicles and offices than in homes [Carignan et al. 2013]. Office participants had an increase in median hand levels of TDCIPP across the shifts, yet GM and median urine concentrations of BDCIPP decreased. This was unexpected considering that animal studies show absorption through the skin and gastrointestinal tract [Nomeir et al. 1981]. The half-life of TDCIPP in rats is between 1.5 and 5.4 hours [Nomeir et al. 1981] so perhaps urine concentrations of BDCIPP peaked sometime between the end of the shift and the beginning of the next shift because of hand exposure continuing until the end of the shift. 
Urinary BCIPP and BCEP concentrations in our participants were lower than what has been found in the general population. Urinary TBBA was not detected in any of our samples. One study of 52 U.S. adults reported a GM concentration of $0.0056 \mu \mathrm{g} / \mathrm{L}$. Because our LOD was $0.05 \mu \mathrm{g} / \mathrm{L}$, we may have been unable to detect it [Hoffman et al. 2014]. Urinary DoCP and DpCP (metabolites of TCP, which is also used in plastic housings of electronics) were mostly not detected, despite TCP being present in the second highest GM and median airborne concentrations, after TCIPP. GM and median hand wipe levels of TCP also increased from the preshift to postshift levels for all participants, with the biggest differences and highest concentrations among refurbishing and resale participants. The absence of urinary metabolites could be due to a variety of reasons. Urine may not be an important route of excretion for TCP in humans. Kurebayashi et al. [1985] found that TCP was excreted mainly in the feces $(77 \%)$ and not the urine $(12 \%)$ of rats after a single oral dose. In addition, dermal or inhalation absorption may be poor.

\section{Biological Burden of Flame Retardants: Uncertainty Regarding Health Effects}

Recognition of the potential adverse effects of exposure to flame retardants is relatively recent; this is unlike lead, the effects of which have been recognized and associated with BLL. Some human epidemiologic studies have shown an association between exposure to certain flame retardants and changes in male reproductive hormones, semen quality, thyroid homeostasis, hormone levels and fertility in women; cryptorchidism (undescended testicles); low birth weight and length; delayed motor skills; decreased IQ; and cancer [Abdallah et al. 2015; Czerska et al. 2013; Dallaire et al. 2009; Dishaw et al. 2014; Grant et al. 2013; Johnson et al. 2013; Meeker and Stapleton 2010; Meeker et al. 2013a,b; van der Veen and de Boer 2012]. However, it is not clear at what levels these effects begin to occur. Evaluations like this one help us identify populations with potential exposure and may help establish baseline levels to evaluate employees in at-risk industries during future research.

\section{Workplace Observations and Ergonomic Hazards}

Employees worked in awkward postures, used forceful exertions, performed repetitive motions, worked in a standing posture for prolonged periods of time, and worked in stations with sub-optimal lighting. These activities can lead to musculoskeletal disorders. Musculoskeletal disorders are conditions that involve the nerves, tendons, muscles, and supporting structures of the body. They can be characterized by chronic pain and limited mobility. Evidence shows job tasks that require a combination of risk factors (highly repetitious, forceful hand/wrist exertions) increase risk for hand/wrist tendinitis [NIOSH 1997]. Additionally, low back disorders are associated with work-related lifting, forceful movements, and awkward postures such as bending and twisting [NIOSH 1997]. Although personal factors such as age, sex, smoking, physical activity, strength, and body measurements may affect an individual's susceptibility to overexertion injuries/disorders, studies conducted in high-risk industries show that the risk associated with these personal factors is smaller than the risk associated with their occupational exposures [NIOSH 1997]. 
The Canadian Centre for Occupational Health and Safety reports that working in a standing posture on a regular basis can cause sore feet, swelling of the legs, varicose veins, general muscular fatigue, low back pain, stiffness in the neck and shoulders, and other health problems. The Centre suggests the use of floor mats (anti-fatigue mats) to avoid health problems [Canadian Centre for Occupational Health and Safety 2011].

Employees stated that the lighting at the disassembly workstations was too bright, so they elected not to use them. Good lighting design should include both human perception and numerical standards. The selection of lighting in the workspace should support the work, but consider user satisfaction to facilitate work performance. Lower wattage lights or warmer tones may help with employee satisfaction.

\section{Noise Measurements}

Measurements taken with the sound level meter showed peak impulsive sound levels exceeding $120 \mathrm{~dB}$, but below the OSHA PEL and NIOSH REL of $140 \mathrm{~dB}$. Repeated exposure to impulse noise can result in permanent noise-induced hearing loss [Chan et al. 2001; Patterson and Hamernik 1992; Pekkarinen et al. 1993]. Impulsive noise of sufficient intensity can permanently damage unprotected ears in minutes rather than the days or years typical of continuous industrial noise exposures. Additional factors such as duration of the impulse and frequency of exposure can also affect risk of hearing loss.

We observed employees using disposable foam insert ear plugs incorrectly. Proper insertion of hearing protection is important to ensure proper noise attenuation. NIOSH has previously identified that poor insertion of formable hearing protection into the ear canals reduces the ability of hearing protectors to attenuate all types of noise exposure [NIOSH 2005]. During our sampling we did not use personal noise dosimeters to assess employee exposures and therefore our sampling cannot be used to compare against full-shift time-weighted average (TWA) noise exposure limits.

\section{Conclusions}

Employees at this electronics recycling company were exposed to metals including lead and cadmium; however, no OELs were exceeded. Although blood and air sampling results indicate exposures are well controlled, our handwipe sampling demonstrates that there is potential for take-home contamination of lead and other metals. Surface wipe samples for flame retardants indicated that flame retardants were present in the workplace. Air and handwipe samples indicate that employees are exposed to flame retardants. Biological samples show that exposures have not led to a noticeable uptake over a shift. Exposure levels are typically lower than what has been seen in other electronic recycling companies. We believe the uptake of flame retardants in the body is potentially hazardous to human health, and continued efforts to minimize exposures should be undertaken. We found that employees sometimes worked in awkward postures, used forceful exertions, performed repetitive motions, stood for prolonged periods, and worked at times in sub-optimal lighting. These conditions can lead to musculoskeletal disorders. 


\section{Recommendations}

On the basis of our findings, we recommend the actions listed below. We encourage the electronics recycling company to use a labor-management health and safety committee or working group to discuss our recommendations and develop an action plan. Those involved in the work can best set priorities and assess the feasibility of our recommendations for the specific situation at the electronics recycling company.

Our recommendations are based on an approach known as the hierarchy of controls (Appendix B). This approach groups actions by their likely effectiveness in reducing or removing hazards. In most cases, the preferred approach is to eliminate hazardous materials or processes and install engineering controls to reduce exposure or shield employees. Until such controls are in place, or if they are not effective or feasible, administrative measures and PPE may be needed.

\section{Engineering Controls}

Engineering controls reduce employees' exposures by removing the hazard from the process or by placing a barrier between the hazard and the employee. Engineering controls protect employees effectively without placing primary responsibility of implementation on the employee.

1. Adjust computer monitors in the refurbishing department.

- The top of the monitor should be adjustable and between 58 inches and 71 inches above the floor. If adjustability is not an option, a fixed height of 66 inches is recommended.

- The optimal distance from the eye to the monitor should be adjustable between 18 inches and 30 inches or fixed at 23 inches. If the monitors are located more than 30 inches away, larger font or monitors should be used.

2. Provide keyboard trays mounted on the workstations in the refurbishing department. The keyboards should be located to reduce reach distances and awkward wrist postures.

3. Design the disassembly workstations for adjustability.

- Standing hand working height should be adjustable from 38 inches to 47 inches or fixed at 42 inches.

- Parts and bins supporting the process should be placed in front of the employee with less than 16 inches reaching distance.

- All work should be performed within 22 inches from the edge of the workstation to eliminate extended reaches.

- Provide lift tables or load levelers for palletized materials. A rotating top will help reduce reach distances if access is not available on three sides of the pallet.

4. Design a platform around the small shredder. The platform should be high enough to reduce the reach distance to the entry port below shoulder height. The scissor lift holding the small totes would need to be adjusted to accommodate the height.

5. Provide a tilt mechanism for the large totes at the small shredder area to reduce bending at the waist to reach parts from the bottom of the large tote. 
6. Replace anti-fatigue mats for employees who stand for $90 \%$ or more of their working hours. Mats should be $\geq 0.5$ inches thick and have an optimal compressibility of $3 \%-4 \%$. Mats should have beveled edges, cover the entire area that employees move, and be placed at least 8 inches under a workstation to prevent uneven standing surfaces and trip hazards. Replace mats when they appear worn out or damaged.

7. Change the bulbs in individual workstations to less wattage or warmer tones, so that employees have appropriate light to complete their work without bending over or relying on awkward positions to complete their work tasks.

\section{Administrative Controls}

The term administrative controls refers to employer-dictated work practices and policies to reduce or prevent hazardous exposures. Their effectiveness depends on employer commitment and employee acceptance. Regular monitoring and reinforcement are necessary to ensure that policies and procedures are followed consistently.

1. For employees with exposures to lead, such as disassembly employees, refer to the Association of Occupational and Environmental Clinics published guidelines for the management of adult lead exposure [Kosnett et al. 2007]. Provide employees with the results of their individual BLLs in writing after each blood draw. In the event that processes change, including an increase or change in type of electronics recycled, additional controls such as providing work uniforms, change rooms, and more frequent BLL testing may be required.

2. Provide employees with a lead-removing product to wash their hands when they leave the processing area, and before eating, drinking, or smoking. Learn more about commercially available lead removal products by reading "Information for Workers, How You Can Keep Yourself and Your Family Safe from Lead" available at http://www.cdc.gov/niosh/topics/lead/safe.html.

3. Prohibit dry sweeping. Use wet cleaning methods or high-efficiency particulate air vacuuming instead. When cleaning metals scraps or loose screws, rather than sweeping, a magnetic device can be used to remove these objects from the work bench or below the workstation.

4. Measure employees' full shift TWA noise exposures during shredding operations and for the employees near the shredder to determine if employees' exposures are above occupational noise exposure limits. 


\section{Personal Protective Equipment}

PPE is the least effective means for controlling hazardous exposures. Proper use of PPE requires a comprehensive program and a high level of employee involvement and commitment. The right PPE must be chosen for each hazard. Supporting programs such as training, change-out schedules, and medical assessment may be needed. PPE should not be the sole method for controlling hazardous exposures. Rather, PPE should be used until effective engineering and administrative controls are in place.

1. Require employees who voluntarily use disposable filtering facepiece respirators to wear them properly. Guidelines for putting on and taking off a disposable respirator are available at http://www.cdc.gov/niosh/docs/2010-133/pdfs/2010-133.pdf.

2. Provide clean gloves for daily use, or use clean nitrile gloves when reusing dirty gloves. Encourage employees to replace dirty gloves frequently to minimize contamination of surfaces with metals.

3. Train employees on the proper insertion and use of disposable ear plugs, even if worn voluntarily. 


\section{Appendix A: Tables}

Table A1. Flame retardants sampled during this evaluation and where they are typically found

\begin{tabular}{|c|c|c|}
\hline Flame retardant & $\begin{array}{l}\text { CAS } \\
\text { number }\end{array}$ & Typically found in \\
\hline \multicolumn{3}{|c|}{ Commonly used in electronics until around 2004} \\
\hline $\begin{array}{l}\text { Octabromodiphenyl ether } \\
\text { technical mixture (OctaBDE) }\end{array}$ & $32536-52-0$ & $\begin{array}{l}\text { Acrylonitrile-butadiene-styrene resins and housings for } \\
\text { electrical equipment; not used in United States since } 2004\end{array}$ \\
\hline \multicolumn{3}{|c|}{ Commonly used in electronics until around 2013} \\
\hline $\begin{array}{l}\text { Decabromodiphenyl ether } \\
\text { technical mixture (DecaBDE) }\end{array}$ & $1163-19-5$ & $\begin{array}{l}\text { High impact polystyrene for television and computer monitor } \\
\text { housings, polycarbonate and polymer resins, rubber; } \\
\text { not used in United States since } 2013\end{array}$ \\
\hline \multicolumn{3}{|c|}{ Commonly used in electronics now and in the past } \\
\hline $\begin{array}{l}\text { Tris(phenyl) phosphate } \\
\text { (TPHP) }\end{array}$ & 115-86-6 & $\begin{array}{l}\text { High impact polystyrene and acrylonitrile-butadiene-styrene } \\
\text { plastics for electronics housings, printed wiring boards, } \\
\text { synthetic resins and decorative laminated sheets, } \\
\text { photographic film, plasticizer in lacquers, varnishes, and } \\
\text { hot melt adhesives, in roofing paper, component of } \\
\text { Firemaster } 550 \text { (used as a PentaBDE replacement in foam) }\end{array}$ \\
\hline Tricresyl phosphate (TCP) & $1330-78-5$ & $\begin{array}{l}\text { Polystyrene and plastics for housings, rubbers, cables, } \\
\text { hoses, conveyor belts, waterproofing }\end{array}$ \\
\hline $\begin{array}{l}\text { Decabromodiphenyl } \\
\text { ethane (DBDPE) }\end{array}$ & $84852-53-9$ & $\begin{array}{l}\text { Used as a replacement for DecaBDE) in high impact } \\
\text { polystyrene and acrylonitrile-butadiene-styrene plastics for } \\
\text { electronics housings, wires and cables, and textiles }\end{array}$ \\
\hline $\begin{array}{l}\text { 1,2-Bis }(2,4,6- \\
\text { tribromophenoxy)ethane } \\
\text { (BTBPE) }\end{array}$ & $37853-59-1$ & $\begin{array}{l}\text { Firemaster } 680 \text { (a replacement for OctaBDE) in high impact } \\
\text { polystyrene and acrylonitrile-butadiene-styrene plastics for } \\
\text { electronics housings, thermoplastics, elastomers, adhesives } \\
\text { and coatings }\end{array}$ \\
\hline $\begin{array}{l}\text { Tetrabromobisphenol-A } \\
\text { (TBBPA) }\end{array}$ & 79-94-7 & Printed circuit boards, epoxies, and polycarbonate resins \\
\hline
\end{tabular}

Less commonly used in electronics now and in the past 2-ethylhexyl 2,3,4,5tetrabromobenzoate (EH-TBB)

Bis(2-ethylhexyl) tetrabromophthalate (BEH-TEBP)

Tris(chloroethyl) phosphate (TCEP)

Tris(2-chloroisopropyl)

$\alpha-, \beta-, y$

Hexabromocyclododecane $(\alpha-, \beta-$, y HBCD) phosphate (TCIPP)
183658-27-7 Firemaster 550 (used as a replacement for PentaBDE in insulation, coated fabrics

26040-51-7 Firemaster 550 (used as a replacement for PentaBDE in foam), also for flexible polyvinyl chloride, wire and cable insulation, film and sheeting, coated fabrics, wall coverings, and adhesives

115-96-8 Polyester resins, adhesives, and coatings

13674-84-5 Polyurethane rigid and flexible foam, polyvinyl chloride, and epoxy resin, thermosets and thermoplastics, textile finishes

134237-50-6 Polystyrene for building construction, high impact polystyrene 134237-51-7 for electronics casings, acrylic and latex dispersions 134237-52-8 (textile backings) foam), polyvinyl chloride and neoprene, wire and cable

\section{Rarely used in electronics}

Pentabromodiphenyl ether technical mixture (PentaBDE)

32534-81-9 Polyurethane foam and textiles, so often present in dusts; not used in United States since 2004

Tris(1,3-dichloro-2-propyl) phosphate (TDCIPP)

13674-87-8 Polyurethane foam

CAS $=$ Chemical abstract service 
Table A2. Major congeners of PentaBDE, OctaBDE, and DecaBDE [Alaee et al 2003]

\begin{tabular}{|c|c|c|}
\hline $\begin{array}{l}\text { Flame retardant and } \\
\text { major congeners }\end{array}$ & CAS Number & Percentage \\
\hline PentaBDE & $32534-81-9$ & \\
\hline BDE-99* & 60348-60-9 & $45 \%-49 \%$ \\
\hline $\mathrm{BDE}-47^{*}$ & $5436-43-1$ & $38 \%-42 \%$ \\
\hline BDE-100 & 189084-64-8 & $7.5 \%-13 \%$ \\
\hline BDE-153‡ & 68631-49-2 & $5.3 \%-4.0 \%$ \\
\hline BDE-154‡ & $207122-15-4$ & $2.7 \%-4.5 \%$ \\
\hline BDE-85 & $182346-21-0$ & $2.2 \%-3.0 \%$ \\
\hline OctaBDE & $32536-52-0$ & \\
\hline BDE-183* & $207122-16-5$ & $13 \%-42 \%$ \\
\hline BDE-209† & $145538-75-5$ & $1.3 \%-50 \%$ \\
\hline DecaBDE & $1163-19-5$ & \\
\hline BDE-209 & $145538-75-5$ & $97 \%-98 \%$ \\
\hline BDE-206§ & 63387-28-0 & low \\
\hline
\end{tabular}

*These congeners are used as markers for their parent chemicals.

†Photolytic debromination of BDE-209 can form BDE-183 [Stapleton and Dodder 2008].

$\ddagger$ These can also be components of OctaBDE.

§This is also a breakdown product of BDE-209. 
Table A3. Results of personal air samples for metals (in $\mu \mathrm{g} / \mathrm{m}^{3}$ ) collected over two days for 15 employees $(n=38)^{*}$

\begin{tabular}{|c|c|c|c|c|}
\hline Metal & Median & GM (range) & Lowest OEL & Agency \\
\hline Aluminum & 1.2 & 1.17 (ND-6.1) & 10,000 & $\mathrm{NIOSH}$ \\
\hline Antimony & ND & ND & 500 & OSHA/NIOSH/ACGIH \\
\hline Arsenic & ND & ND (ND-0.66) & 10 & $\mathrm{ACGIH}$ \\
\hline Barium & 0.45 & $0.36(0.05-1.7)$ & 500 & OSHA/NIOSH/ACGIH \\
\hline Beryllium & ND & ND & 0.05 & ACGIH \\
\hline Cadmium & ND & ND (ND-0.03) & 5 & OSHA \\
\hline Calcium & 11 & 12 (ND-28) & $\mathrm{N} / \mathrm{A}$ & N/A \\
\hline Chromium & ND & ND & 500 & $\mathrm{NIOSH} / \mathrm{ACGIH}$ \\
\hline Cobalt & ND & ND & 20 & ACGIH \\
\hline Copper & ND & ND (ND-3.2) & 1,000 & $\mathrm{NIOSH} / \mathrm{OSH} / \mathrm{ACGIH}$ \\
\hline Indium & ND & ND & 100 & NIOSH/ACGIH \\
\hline Iron & 4.4 & 4.73 (ND-19) & 5,000 & $\mathrm{NIOSH} / \mathrm{ACGIH}$ \\
\hline Lanthanum & ND & ND (ND-0.03) & $\mathrm{N} / \mathrm{A}$ & $\mathrm{N} / \mathrm{A}$ \\
\hline Lead & 0.14 & 0.133 (ND-0.37) & 50 & OSHA/NIOSH/ACGIH \\
\hline Lithium & ND & ND (ND-0.08) & N/A & N/A \\
\hline Magnesium & ND & 1.84 (ND-5.3) & 10,000 & ACGIH \\
\hline Manganese & ND & 0.231 (ND-6.5) & 100 & ACGIH \\
\hline Molybdenum & ND & ND (ND-0.09) & 10,000 & ACGIH \\
\hline Nickel & ND & 0.129 (ND-0.46) & 15 & $\mathrm{NIOSH}$ \\
\hline Phosphorus & ND & ND (ND-1.2) & 100 & OSHA/NIOSH/ACGIH \\
\hline Potassium & 0.86 & 0.751 (ND-2.6) & $\mathrm{N} / \mathrm{A}$ & $N / A$ \\
\hline Selenium & ND & ND & 200 & OSHA/NIOSH/ACGIH \\
\hline Silver & ND & 0.01 (ND-0.08) & 10 & OSHA/NIOSH \\
\hline Strontium & 0.11 & 0.097 (ND-0.99) & $\mathrm{N} / \mathrm{A}$ & N/A \\
\hline Tellurium & ND & ND & 100 & OSHA/NIOSH/ACGIH \\
\hline Thallium & ND & ND & 20 & $\mathrm{ACGIH}$ \\
\hline Tin & ND & ND (ND-0.78) & 2,000 & OSHA/NIOSH/ACGIH \\
\hline Titanium & 0.16 & 0.14 (ND-0.55) & N/A & N/A \\
\hline Vanadium & ND & ND & $\mathrm{N} / \mathrm{A}$ & $\mathrm{N} / \mathrm{A}$ \\
\hline Yttrium & ND & $0.01(N D-0.04)$ & 1,000 & OSHA/NIOSH/ACGIH \\
\hline Zinc & 0.98 & 0.959 (ND-7.8) & 5,000 & $\mathrm{NIOSH}$ \\
\hline Zirconium & 0.04 & $0.03(\mathrm{ND}-0.31)$ & 5,000 & OSHA/NIOSH/ACGIH \\
\hline
\end{tabular}


Table A4. Comparing selected PPs found in the blood of electronics recycling employees with the National Health and Nutrition Examination Survey for the general population, in $\mathrm{ng} / \mathrm{g}$ lipid weight

\begin{tabular}{|c|c|c|c|c|c|c|}
\hline \multirow[t]{2}{*}{ Persistent pesticide } & \multicolumn{3}{|c|}{$\begin{array}{l}\text { Electronics recycling } \\
\text { company participants } \\
\qquad(\mathrm{n}=19)\end{array}$} & \multicolumn{3}{|c|}{$\begin{array}{l}\text { National Health and } \\
\text { Nutrition Examination Survey } \\
(2003-2004)\end{array}$} \\
\hline & Median & GM & Maximum & Median & GM & $\begin{array}{c}\text { 95th } \\
\text { percentile }\end{array}$ \\
\hline $\begin{array}{l}\text { Polybrominated } \\
\text { biphenyl } 153\end{array}$ & 4.57 & 4.74 & 19.2 & 2.50 & 2.72 & 34.6 \\
\hline Hexachlorobenzene & 6.55 & 6.69 & 10.2 & 15.1 & 15.5 & 29.0 \\
\hline $\begin{array}{l}\text { Beta- } \\
\text { hexachlorocyclohexane }\end{array}$ & ND & ND & 4.64 & ND & 7.89 & 62.2 \\
\hline Oxychlordane & 2.94 & 3.33 & 13.0 & 11.4 & 10.6 & 39.2 \\
\hline Trans-nonchlor & 6.45 & 5.29 & 28.3 & 17.3 & 16.9 & 74.7 \\
\hline $\begin{array}{l}p, p^{\prime} \text {-dichlorodiphenyl } \\
\text { trichloroethene }\end{array}$ & 88.7 & 121 & 2,281 & 233 & 268 & 1,990 \\
\hline $\begin{array}{l}\text { o,p'-dichlorodiphenyl } \\
\text { trichloroethane }\end{array}$ & ND & ND & 12.4 & $\begin{array}{l}\text { Not } \\
\text { reported }\end{array}$ & ND & ND \\
\hline $\begin{array}{l}p, p^{\prime} \text {-dichlorodiphenyl } \\
\text { trichloroethane }\end{array}$ & 2.33 & 3.83 & 362 & $\begin{array}{l}\text { Not } \\
\text { reported }\end{array}$ & ND & 20.7 \\
\hline
\end{tabular}

Table A5. Comparing selected PCBs found in the blood of electronics recycling employees with the National Health and Nutrition Examination Survey for the general population, in $\mathrm{ng} / \mathrm{g}$ lipid weight

\begin{tabular}{lcccccc}
\hline $\begin{array}{l}\text { Polychlorinated } \\
\text { biphenyl }\end{array}$ & \multicolumn{3}{c}{$\begin{array}{c}\text { Electronics recycling company } \\
\text { participants } \\
(\mathrm{n}=19)\end{array}$} & \multicolumn{3}{c}{$\begin{array}{c}\text { National Health and } \\
\text { Nutrition Examination Survey } \\
(2003-2004)\end{array}$} \\
\cline { 2 - 5 } & Median & GM & Maximum & Median & GM & $\begin{array}{c}\text { 95th } \\
\text { percentile }\end{array}$ \\
\hline $\begin{array}{l}\text { Polychlorinated } \\
\text { biphenyl 28 }\end{array}$ & 1.38 & 1.28 & 3.68 & 4.98 & 4.88 & 11.1 \\
$\begin{array}{l}\text { Polychlorinated } \\
\text { biphenyl 66 }\end{array}$ & 0.64 & 0.92 & 8.28 & 1.40 & 1.42 & 4.20 \\
$\begin{array}{l}\text { Polychlorinated } \\
\text { biphenyl 74 }\end{array}$ & 2.11 & 2.26 & 12.7 & 5.00 & 5.38 & 24.1 \\
$\begin{array}{l}\text { Polychlorinated } \\
\text { biphenyl 99 }\end{array}$ & 1.69 & 2.08 & 12.4 & 4.08 & 4.52 & 18.6 \\
$\begin{array}{l}\text { Polychlorinated } \\
\text { biphenyl 153 }\end{array}$ & 9.73 & 8.35 & 32.4 & 24.2 & 23.7 & 101 \\
$\begin{array}{l}\text { Polychlorinated } \\
\text { biphenyl 156 }\end{array}$ & 1.14 & 0.895 & 2.56 & 4.10 & 3.31 & 16.8 \\
$\begin{array}{l}\text { Polychlorinated } \\
\text { biphenyl 170 }\end{array}$ & 2.20 & 1.79 & 6.21 & 7.83 & 6.86 & 29.5 \\
$\begin{array}{l}\text { Polychlorinated } \\
\text { biphenyl 180 }\end{array}$ & 1.81 & 1.92 & 9.94 & 5.71 & 5.20 & 25.9 \\
$\begin{array}{l}\text { Polychlorinated } \\
\text { biphenyl 187 }\end{array}$ & 5.63 & 4.83 & 16.6 & 21.5 & 19.0 & 88.0 \\
\hline
\end{tabular}


Table A6. Creatinine uncorrected concentrations of flame retardant metabolites in urine of electronics recycling employees and in the National Health and Nutrition Examination Survey, in $\mu \mathrm{g} / \mathrm{L}^{*}$

\begin{tabular}{|c|c|c|c|c|c|c|}
\hline & \multicolumn{3}{|c|}{$\begin{array}{l}\text { Electronics recycling company } \\
\text { participants }(n=17)\end{array}$} & \multicolumn{3}{|c|}{$\begin{array}{c}\text { National Health and } \\
\text { Nutrition Examination Survey† }\end{array}$} \\
\hline & Median & GM & Max & Median & GM & $\begin{array}{c}\text { 95th } \\
\text { percentile }\end{array}$ \\
\hline \multicolumn{7}{|c|}{ Commonly used in electronics now and in the past } \\
\hline $\begin{array}{l}\text { DPHP }(\text { TPHP }) \S \\
\text { LOD }=0.16\end{array}$ & 0.41 & 0.40 & 1.5 & 0.73 & 0.76 & 5.5 \\
\hline $\begin{array}{l}\mathrm{DpCP}(\mathrm{TCP}) \\
\mathrm{LOD}=0.05\end{array}$ & ND & $\begin{array}{l}\text { Not } \\
\text { calculated }\end{array}$ & ND & ND & $\begin{array}{l}\text { Not } \\
\text { calculated }\end{array}$ & 0.10 \\
\hline $\begin{array}{l}\text { DoCP }(\text { TCP }) \\
\text { LOD }=0.05\end{array}$ & ND & $\begin{array}{l}\text { Not } \\
\text { calculated }\end{array}$ & ND & ND & ND & ND \\
\hline \multicolumn{7}{|c|}{ Less commonly used in electronics now and in the past } \\
\hline $\begin{array}{l}\text { TBBA }(\mathrm{EH}-\mathrm{TBB}) \\
\mathrm{LOD}=0.05\end{array}$ & ND & $\begin{array}{l}\text { Not } \\
\text { calculated }\end{array}$ & ND & ND & ND & ND \\
\hline $\begin{array}{l}\text { BCEP }(\text { TCEP }) \\
\text { LOD }=0.08\end{array}$ & 0.16 & 0.22 & 3.8 & 0.37 & 0.39 & 3.6 \\
\hline $\begin{array}{l}\text { BCIPP (TCIPP) } \\
\text { LOD }=0.10\end{array}$ & 0.16 & $\begin{array}{l}\text { Not } \\
\text { calculated }\end{array}$ & 0.82 & 0.16 & 0.19 & 1.3 \\
\hline \multicolumn{7}{|c|}{ Rarely used in electronics } \\
\hline $\begin{array}{l}\text { BDCIPP (TDCIPP) } \\
\text { LOD }=0.11\end{array}$ & 0.48 & $\begin{array}{l}\text { Not } \\
\text { calculated }\end{array}$ & 3.0 & 0.85 & 0.82 & 6.4 \\
\hline
\end{tabular}

*Samples are the second day of sampling, postshift values.

†Age 20 to 59, $\mathrm{n}=1266$, samples taken 2013 and 2014

ҒGM not calculated if proportion of results below the limit of detection was $70 \%$ or more.

$\S n=16$ for this compound 
Table A7. Creatinine corrected concentrations of flame retardant metabolites in urine of electronics recycling employees and in the National Health and Nutrition Examination Survey, in $\mu \mathrm{g} / \mathrm{g}$ creatinine ${ }^{*} \dagger$

\begin{tabular}{|c|c|c|c|c|c|c|}
\hline & \multicolumn{3}{|c|}{$\begin{array}{l}\text { Electronics recycling company } \\
\text { participants }(n=17)\end{array}$} & \multicolumn{3}{|c|}{$\begin{array}{c}\text { National Health and } \\
\text { Nutrition Examination Survey } \ddagger\end{array}$} \\
\hline & Median & GM§ & Max & Median & GM & $\begin{array}{c}\text { 95th } \\
\text { percentile }\end{array}$ \\
\hline \multicolumn{7}{|c|}{ Commonly used in electronics now and in the past } \\
\hline DPHP (TPHP) & 0.40 & 0.40 & 1.2 & 0.70 & 0.79 & 4.7 \\
\hline $\mathrm{DpCP}(\mathrm{TCP})$ & ND & $\begin{array}{l}\text { Not } \\
\text { calculated }\end{array}$ & ND & ND & $\begin{array}{l}\text { Not } \\
\text { calculated }\end{array}$ & 0.18 \\
\hline DoCP (TCP) & ND & $\begin{array}{l}\text { Not } \\
\text { calculated }\end{array}$ & ND & ND & ND & ND \\
\hline \multicolumn{7}{|c|}{ Less commonly used in electronics now and in the past } \\
\hline TBBA (EH-TBB) & ND & $\begin{array}{l}\text { Not } \\
\text { calculated }\end{array}$ & ND & ND & ND & ND \\
\hline BCEP (TCEP) & 0.18 & 0.22 & 1.5 & 0.33 & 0.41 & 3.3 \\
\hline BCIPP (TCIPP) & 0.14 & 0.15 & 0.91 & 0.18 & 0.20 & 1.3 \\
\hline \multicolumn{7}{|c|}{ Rarely used in electronics } \\
\hline BDCIPP (TDCIPP) & 0.55 & $\begin{array}{l}\text { Not } \\
\text { calculated }\end{array}$ & 1.5 & 0.82 & 0.85 & 4.3 \\
\hline
\end{tabular}

* Limit of detection for creatinine $=1.1 \mathrm{mg} / \mathrm{dL}$

†Samples are the second day of sampling, postshift values.

$\ddagger$ Age 20 to 59, $\mathrm{n}=1266$, samples taken 2013 and 2014

$\S G M$ not calculated if proportion of results below the limit of detection was $70 \%$ or more.

In $=16$ for this compound 


\section{Appendix B: Occupational Exposure Limits and Health Effects}

NIOSH investigators refer to mandatory (legally enforceable) and recommended OELs for chemical, physical, and biological agents when evaluating workplace hazards. OELs have been developed by federal agencies and safety and health organizations to prevent adverse health effects from workplace exposures. Generally, OELs suggest levels of exposure that most employees may be exposed to for up to 10 hours per day, 40 hours per week, for a working lifetime, without experiencing adverse health effects. However, not all employees will be protected if their exposures are maintained below these levels. Some may have adverse health effects because of individual susceptibility, a pre-existing medical condition, or a hypersensitivity (allergy). In addition, some hazardous substances act in combination with other exposures, with the general environment, or with medications or personal habits of the employee to produce adverse health effects. Most OELs address airborne exposures, but some substances can be absorbed directly through the skin and mucous membranes.

Most OELs are expressed as a TWA exposure. A TWA refers to the average exposure during a normal 8- to 10-hour workday. Some chemical substances and physical agents have recommended short-term exposure limit (STEL) or ceiling values. Unless otherwise noted, the STEL is a 15-minute TWA exposure. It should not be exceeded at any time during a workday. The ceiling limit should not be exceeded at any time.

In the United States, OELs have been established by federal agencies, professional organizations, state and local governments, and other entities. Some OELs are legally enforceable limits; others are recommendations.

- The U.S. Department of Labor OSHA PELs (29 CFR 1910 [general industry]; 29 CFR 1926 [construction industry]; and 29 CFR 1917 [maritime industry]) are legal limits. These limits are enforceable in workplaces covered under the Occupational Safety and Health Act of 1970.

- NIOSH RELs are recommendations based on a critical review of the scientific and technical information and the adequacy of methods to identify and control the hazard. NIOSH RELs are published in the NIOSH Pocket Guide to Chemical Hazards [NIOSH 2010]. NIOSH also recommends risk management practices (e.g., engineering controls, safe work practices, employee education/training, PPE, and exposure and medical monitoring) to minimize the risk of exposure and adverse health effects.

- Another set of OELs commonly used and cited in the United States is the ACGIH TLVs. The TLVs are developed by committee members of this professional organization from a review of the published, peer-reviewed literature. TLVs are not consensus standards. They are considered voluntary exposure guidelines for use by industrial hygienists and others trained in this discipline "to assist in the control of health hazards" [ACGIH 2018]. 
Outside the United States, OELs have been established by various agencies and organizations and include legal and recommended limits. The Institut für Arbeitsschutz der Deutschen Gesetzlichen Unfallversicherung (Institute for Occupational Safety and Health of the German Social Accident Insurance) maintains a database of international OELs from European Union member states, Canada (Québec), Japan, Switzerland, and the United States. The database, available at http://www.dguv.de/ifa/GESTIS/GESTIS-Internationale-Grenzwerte-fürchemische-Substanzen-limit-values-for-chemical-agents/index-2.jsp, contains international limits for more than 2,000 hazardous substances and is updated periodically.

OSHA requires an employer to furnish employees a place of employment free from recognized hazards that cause or are likely to cause death or serious physical harm [Occupational Safety and Health Act of 1970 (Public Law 91-596, sec. 5(a)(1))]. This is true in the absence of a specific OEL. It also is important to keep in mind that OELs may not reflect current health-based information.

When multiple OELs exist for a substance or agent, NIOSH investigators generally encourage employers to use the lowest OEL when making risk assessment and risk management decisions. NIOSH investigators also encourage use of the hierarchy of controls approach to eliminate or minimize workplace hazards. This includes, in order of preference, the use of (1) substitution or elimination of the hazardous agent, (2) engineering controls (e.g., local exhaust ventilation, process enclosure, dilution ventilation), (3) administrative controls (e.g., limiting time of exposure, employee training, work practice changes, medical surveillance), and (4) PPE (e.g., respiratory protection, gloves, eye protection, hearing protection). Control banding, a qualitative risk assessment and risk management tool, is a complementary approach to protecting employee health. Control banding focuses on how broad categories of risk should be managed. Information on control banding is available at http://www.cdc.gov/niosh/topics/ctrlbanding/. This approach can be applied in situations where OELs have not been established or can be used to supplement existing OELs.

\section{Lead}

Inorganic lead is a naturally occurring, soft metal that has been mined and used in industry since ancient times. It comes in many forms (e.g., lead acetate, lead chloride, lead chromate, lead nitrate, lead oxide, lead phosphate, and lead sulfate). Lead is considered toxic to all organ systems and serves no useful purpose in the body.

Occupational exposure to inorganic lead occurs via inhalation of lead-containing dust and fume and ingestion of lead particles from contact with lead-contaminated surfaces. Exposure may also occur through transfer of lead to the mouth from contaminated hands or cigarettes when careful attention to hygiene, particularly hand washing, is not practiced. In addition to the inhalation and ingestion routes of exposure, lead can be absorbed through the skin, particularly through damaged skin [Filon et al. 2006; Stauber et al. 1994; Sun et al. 2002].

Workplace settings with exposure to lead and lead compounds include smelting and refining, scrap metal recovery, automobile radiator repair, construction and demolition (including abrasive blasting), and firing ranges. Occupational exposures also occur among workers who apply or remove lead-based paint and among welders who burn or torch-cut metal structures. 


\section{Blood Lead Levels}

In most cases, an individual's BLL is a good indication of recent exposure to lead because the half-life of lead (the time interval it takes for the quantity in the body to be reduced by half its initial value) is 1-2 months [CDC 2013a; Lauwerys and Hoet 2001; Moline and Landrigan 2005]. Most lead in the body is stored in the bones, with a half-life of years to decades. Measuring bone lead, however, is primarily done only for research. Elevated zinc protoporphyrin levels have also been used as an indicator of chronic lead intoxication; however, other factors, such as iron deficiency, can cause an elevated zinc protoporphyrin level, so monitoring the BLL over time is more specific for evaluating chronic occupational lead exposure.

BLLs in adults in the United States have declined consistently over time. The GM BLL went from $1.75 \mu \mathrm{g} / \mathrm{dL}$ in 1999-2000 to $1.09 \mu \mathrm{g} / \mathrm{dL}$ in 2011-2012 [CDC 2015b]. The National Institute for Occupational Safety and Health (NIOSH) Adult Blood Lead Epidemiology and Surveillance System (ABLES) uses a surveillance case definition for an elevated BLL in adults of $5 \mu \mathrm{g} / \mathrm{dL}$ of blood or higher [CDC 2015a]. Very high BLLs are defined as BLLs $\geq 40 \mu \mathrm{g} / \mathrm{dL}$. From 2002-2011, occupational exposures accounted for $91 \%$ of adults with very high BLLs (where exposure source was known) [CDC 2013b]. This underscores the need to increase efforts to prevent lead exposures in the workplace.

\section{Occupational Exposure Limits}

In the United States, employers in general industry are required by law to follow the OSHA lead standard (29 CFR 1910.1025). This standard was established in 1978 and has not yet been updated to reflect the current scientific knowledge regarding the health effects of lead exposure.

Under this standard, the PEL for airborne exposure to lead is $50 \mu \mathrm{g} / \mathrm{m}^{3}$ of air for an 8-hour TWA. The standard requires lowering the PEL for shifts that exceed 8 hours, medical monitoring for employees exposed to airborne lead at or above the action level of $30 \mu \mathrm{g} / \mathrm{m}^{3}$ (8-hour TWA), medical removal of employees whose average BLL is $50 \mu \mathrm{g} / \mathrm{dL}$ or greater, and economic protection for medically removed workers. Medically removed workers cannot return to jobs involving lead exposure until their BLL is below $40 \mu \mathrm{g} / \mathrm{dL}$.

In the United States, other guidelines for lead exposure, which are not legally enforceable, are often followed. Similar to the OSHA lead standard, these guidelines were set years ago and have not yet been updated to reflect current scientific knowledge. NIOSH has a REL for lead of $50 \mu \mathrm{g} / \mathrm{m}^{3}$ averaged over an 8-hour work shift [NIOSH 2010]. The American Conference of Governmental Industrial Hygienists has a TLV for lead of $50 \mu \mathrm{g} / \mathrm{m}^{3}$ (8-hour TWA), with worker BLLs to be controlled to, or below, $30 \mu \mathrm{g} / \mathrm{dL}$. The American Conference of Governmental Industrial Hygienists designates lead as an animal carcinogen [ACGIH 2018]. In 2013, the California Department of Public Health (CDPH) recommended that Cal/ OSHA lower the PEL for lead to 0.5 to $2.1 \mu \mathrm{g} / \mathrm{m}^{3}$ (8-hour TWA) to keep BLLs below the range of 5 to $10 \mu \mathrm{g} / \mathrm{dL}$ [Billingsley 2013].

Neither NIOSH nor OSHA has established surface contamination limits for lead in the workplace. The U.S. Environmental Protection Agency and the U.S. Department of Housing and Urban Development limit lead on surfaces in public buildings and child-occupied 
housing to less than 40 micrograms of lead per square foot [EPA 1998; HUD 2012]. OSHA requires in its substance-specific standard for lead that all surfaces be maintained as free as practicable of accumulations of lead [29 CFR 1910.1025(h)(1)]. An employer with workplace exposures to lead must implement regular and effective cleaning of surfaces in areas such as change areas, storage facilities, and lunchroom/eating areas to ensure they are as free as practicable from lead contamination [OSHA 2003].

\section{Health Effects}

The PEL, REL, and TLV may prevent overt symptoms of lead poisoning, but do not protect workers from lead's contributions to conditions such as hypertension, renal dysfunction, reproductive, and cognitive effects [Brown-Williams et al. 2009; Holland and Cawthorn 2016; Institute of Medicine 2012; Schwartz and Hu 2007; Schwartz and Stewart 2007]. Generally, acute lead poisoning with symptoms has been documented in persons having BLLs above $70 \mu \mathrm{g} / \mathrm{dL}$. These BLLs are rare today in the United States, largely as a result of workplace controls put in place to comply with current OELs. When present, acute lead poisoning can cause myriad adverse health effects including abdominal pain, hemolytic anemia, and neuropathy. Lead poisoning has, in very rare cases, progressed to encephalopathy and coma [Moline and Landrigan 2005].

People with chronic lead poisoning, which is more likely at current occupational exposure levels, may not have symptoms or they may have nonspecific symptoms that may not be recognized as being associated with lead exposure. These symptoms include headache, joint and muscle aches, weakness, fatigue, irritability, depression, constipation, anorexia, and abdominal discomfort [Moline and Landrigan 2005].

The National Toxicology Program recently released a monograph on the health effects of low-level lead exposure [NTP 2012]. For adults, the National Toxicology Program concluded the following about the evidence regarding health effects of lead (Table B1). 
Table B1. Evidence regarding health effects of lead in adults

\begin{tabular}{|c|c|c|c|}
\hline Health area & $\begin{array}{c}\text { NTP } \\
\text { conclusion }\end{array}$ & Principal health effects & $\begin{array}{l}\text { Blood lead } \\
\text { evidence }\end{array}$ \\
\hline \multirow[t]{3}{*}{ Neurological } & Sufficient & Increased incidence of essential tremor & Yes, $<10 \mu \mathrm{g} / \mathrm{dL}$ \\
\hline & Limited & $\begin{array}{l}\text { Psychiatric effects, decreased hearing, } \\
\text { decreased cognitive function, increased } \\
\text { incidence of amyotrophic lateral sclerosis }\end{array}$ & Yes, $<10 \mu \mathrm{g} / \mathrm{dL}$ \\
\hline & Limited & Increased incidence of essential tremor & Yes, $<5 \mu \mathrm{g} / \mathrm{dL}$ \\
\hline Immune & Inadequate & & Unclear \\
\hline \multirow[t]{2}{*}{ Cardiovascular } & Sufficient & $\begin{array}{c}\text { Increased blood pressure and increased risk } \\
\text { of hypertension }\end{array}$ & Yes, $<10 \mu \mathrm{g} / \mathrm{dL}$ \\
\hline & Limited & $\begin{array}{l}\text { Increased cardiovascular-related mortality } \\
\text { and electrocardiography abnormalities }\end{array}$ & Yes, $<10 \mu \mathrm{g} / \mathrm{dL}$ \\
\hline Renal & Sufficient & Decreased glomerular filtration rate & Yes, $<5 \mu \mathrm{g} / \mathrm{dL}$ \\
\hline \multirow[t]{6}{*}{ Reproductive } & Sufficient & Women: reduced fetal growth & Yes, $<5 \mu \mathrm{g} / \mathrm{dL}$ \\
\hline & Sufficient & $\begin{array}{l}\text { Men: adverse changes in sperm parameters } \\
\text { and increased time to pregnancy }\end{array}$ & Yes, $\geq 15-20 \mu \mathrm{g} / \mathrm{dL}$ \\
\hline & Limited & $\begin{array}{l}\text { Women: increase in spontaneous abortion } \\
\text { and preterm birth }\end{array}$ & Yes, $<10 \mu \mathrm{g} / \mathrm{dL}$ \\
\hline & Limited & Men: decreased fertility & Yes, $\geq 10 \mu \mathrm{g} / \mathrm{dL}$ \\
\hline & Limited & Men: spontaneous abortion & Yes, $\geq 31 \mu \mathrm{g} / \mathrm{dL}$ \\
\hline & Inadequate & $\begin{array}{l}\text { Women and Men: stillbirth, endocrine } \\
\text { effects, birth defects }\end{array}$ & Unclear \\
\hline
\end{tabular}

Various organizations have assessed the relationship between lead exposure and cancer. According to the Agency for Toxic Substances and Disease Registry [ATSDR 2007] and the National Toxicology Program [NTP 2011], inorganic lead compounds are reasonably anticipated to cause cancer in humans. The International Agency for Research on Cancer classifies inorganic lead as probably carcinogenic to humans [IARC 2006b]. According to the American Cancer Society [ACS 2011], some studies show a relationship between lead exposure and lung cancer, but these results might be affected by exposure to cigarette smoking and arsenic. Some studies show a relationship between lead and stomach cancer, and these findings are less likely to be affected by the other exposures. The results of studies looking at other cancers, including brain, kidney, bladder, colon, and rectum, are mixed.

\section{Medical Management}

To prevent acute and chronic health effects, a panel of experts convened by the Association of Occupational and Environmental Clinics published guidelines for the management of adult lead exposure [Kosnett et al. 2007]. The panel recommended BLL testing for all leadexposed employees, regardless of the airborne lead concentration. These recommendations do not apply to pregnant women, who should avoid BLLs $>5 \mu \mathrm{g} / \mathrm{dL}$. Removal from lead exposure should be considered if control measures over an extended period do not decrease BLLs to $<10 \mu \mathrm{g} / \mathrm{dL}$ or an employee has a medical condition that would increase the risk of adverse health effects from lead exposure. These guidelines were endorsed by the Council of State and Territorial Epidemiologists (CSTE) and the CDPH in 2009 and the American 
College of Occupational and Environmental Medicine (ACOEM) in 2010 [ACOEM 2010; CDPH 2009; CSTE 2009]. CSTE published updated guidelines in 2013 to reflect the new definition of an elevated BLL in adults of $5 \mu \mathrm{g} / \mathrm{dl}$ [CSTE 2015]. The CDPH recommended keeping BLLs below 5 to $10 \mu \mathrm{g} / \mathrm{dL}$ in 2013 [Billingsley 2013] and updated their medical management guidelines in 2014 [CDPH 2014]. In 2015, NIOSH designated $5 \mu \mathrm{g} / \mathrm{dL}$ of whole blood, in a venous blood sample, as the reference BLL for adults. An elevated BLL is defined as a BLL $\geq 5 \mu \mathrm{g} / \mathrm{dL}$. In 2016, the ACOEM released a position statement entitled "Workplace Lead Exposure," which reinforces the guidelines and recommendations above [Holland and Cawthorn 2016]. Table B2 incorporates recommendations from the expert panel guidelines and those from CDPH, CSTE, and ACOEM. 
Table B2. Health-based medical surveillance recommendations for lead-exposed employees

\begin{tabular}{|c|c|}
\hline Category of exposure & Recommendations \\
\hline All lead exposed workers & $\begin{array}{l}\text { - Baseline or preplacement medical history and physical } \\
\text { examination, baseline BLL, and serum creatinine }\end{array}$ \\
\hline $\mathrm{BLL}<5 \mu \mathrm{g} / \mathrm{dL}$ & $\begin{array}{l}\text { BLL monthly for first } 3 \text { months placement, or upon change in } \\
\text { task to higher exposure, then BLL every } 6 \text { months; if BLL } \\
\text { increases } \geq 5 \mu \mathrm{g} / \mathrm{dL} \text {, evaluate exposure and protective measures, } \\
\text { and increase monitoring if indicated }\end{array}$ \\
\hline BLL 5-9 $\mu \mathrm{g} / \mathrm{dL}$ & $\begin{array}{l}\text { - Discuss health risks } \\
\text { - Minimize exposure } \\
\text { - Consider removal for pregnancy and certain medical conditions } \\
\text { BLL monthly for first } 3 \text { months placement or every } 2 \text { months for } \\
\text { the first } 6 \text { months placement, or upon change in task to higher } \\
\text { exposure, then BLL every } 6 \text { months; if BLL increases } \geq 5 \mu \mathrm{g} / \mathrm{dL} \text {, } \\
\text { evaluate exposure and protective measures, and increase } \\
\text { monitoring if indicated }\end{array}$ \\
\hline BLL $10-19 \mu \mathrm{g} / \mathrm{dL}$ & $\begin{array}{l}\text { - Discuss health risks } \\
\text { - Decrease exposure } \\
\text { - Remove from exposure for pregnancy } \\
\text { - } \text { Consider removal for certain medical conditions or BLL } \geq 10 \mu \mathrm{g} / \mathrm{dL} \\
\text { for extended period } \\
\text { - } \text { BLL every } 3 \text { months; evaluate exposure, engineering controls, and } \\
\text { work practices; consider removal. } \\
\text { - } \text { Revert to BLL every } 6 \text { months after } 3 \text { BLLs }<10 \mu \mathrm{g} / \mathrm{dL}\end{array}$ \\
\hline BLL 20-29 $\mu \mathrm{g} / \mathrm{dL}$ & $\begin{array}{l}\text { - Remove from exposure for pregnancy } \\
\text { - Remove from exposure if repeat BLL measured in } 4 \text { weeks } \\
\text { remains } \geq 20 \mu \mathrm{g} / \mathrm{dL} \\
\text { - } \text { Annual lead medical exam recommended } \\
\text { - } \text { Monthly BLL testing } \\
\text { - Consider return to work after } 2 \mathrm{BLLs}<15 \mu \mathrm{g} / \mathrm{dL} \text { a month apart, } \\
\text { then monitor as above }\end{array}$ \\
\hline BLL 30-49 $\mu \mathrm{g} / \mathrm{dL}$ & $\begin{array}{l}\text { - Remove from exposure } \\
\text { - Prompt medical evaluation } \\
\text { - } \text { Monthly BLL testing } \\
\text { - Consider return to work after } 2 \mathrm{BLLs}<15 \mu \mathrm{g} / \mathrm{dL} \text { a month apart, } \\
\text { then monitor as above }\end{array}$ \\
\hline BLL 50-79 $\mu \mathrm{g} / \mathrm{dL}$ & $\begin{array}{l}\text { - Remove from exposure } \\
\text { - Prompt medical evaluation } \\
\text { - Consider chelation with significant symptoms }\end{array}$ \\
\hline $\mathrm{BLL} \geq 80 \mu \mathrm{g} / \mathrm{dL}$ & $\begin{array}{l}\text { - Remove from exposure } \\
\text { - Urgent medical evaluation } \\
\text { - Chelation may be indicated }\end{array}$ \\
\hline
\end{tabular}

Adapted from Kosnett et al. 2007, CSTE 2015, and CDPH 2014 


\section{Take-home Contamination}

Occupational exposures to lead can result in exposures to household members, including children, from take-home contamination. Take-home contamination occurs when lead dust is transferred from the workplace on employees' skin, clothing, shoes, and other personal items to their vehicle and home [CDC 2009, 2012].

The CDC considers a BLL in children of $5 \mu \mathrm{g} / \mathrm{dL}$ or higher as a reference level above which public health actions should be initiated, and states that no safe BLL in children has been identified [CDC 2013a].

The U.S. Congress passed the Workers' Family Protection Act in 1992 (29 U.S.C. 671a). The Act required NIOSH to study take-home contamination from workplace chemicals and substances, including lead. NIOSH found that take-home exposure is a widespread problem [NIOSH 1995]. Workplace measures effective in preventing take-home exposures were (1) reducing exposure in the workplace, (2) changing clothes before going home and leaving soiled clothing at work for laundering, (3) storing street clothes in areas separate from work clothes, (4) showering before leaving work, and (5) prohibiting removal of toxic substances or contaminated items from the workplace. NIOSH noted that preventing take-home exposure is critical because decontaminating homes and vehicles is not always effective. Normal house cleaning and laundry methods are inadequate, and decontamination can expose the people doing the cleaning and laundry.

\section{Beryllium, Cadmium, Chromium, Nickel, Manganese, and Cobalt}

Table B3 summarizes the OELs for the other common metals found in electronic scrap recycling, as well as a discussion of the potential health effects from exposure to these elements. 
Table B3. Chemical health effects

\begin{tabular}{|c|c|c|c|}
\hline Chemicals & Health effects & IARC & OEL $\left(\mu \mathrm{g} / \mathrm{m}^{3}\right)$ \\
\hline Beryllium & $\begin{array}{l}\text { Beryllium exposure may cause } \\
\text { dermatitis, lung inflammation, } \\
\text { and chronic beryllium disease in } \\
\text { humans [Proctor et al. 1991] } \\
\text { - Exposure to beryllium can lead } \\
\text { to sensitization } \\
\text { - Exposure also slightly increases } \\
\text { the risk for lung cancer } \\
\text { [Schubauer-Berigan et al. 2010] }\end{array}$ & $\begin{array}{l}\text { Group 1: } \\
\text { carcinogenic } \\
\text { to humans } \\
\text { [IARC 2012] }\end{array}$ & $\begin{array}{l}\text { OSHA PEL: } 2.0 \\
\text { NIOSH REL: } 0.5 \\
\text { ACGIH TLV: } 0.05\end{array}$ \\
\hline Cadmium & $\begin{array}{l}\text { Long-term occupational exposure to } \\
\text { cadmium is associated with } \\
\text { increased occurrence of lung cancer, } \\
\text { kidney damage, and chronic } \\
\text { obstructive lung disease } \\
\text { [WHO 1992] }\end{array}$ & $\begin{array}{l}\text { Group 1: } \\
\text { carcinogenic } \\
\text { to humans } \\
\text { [IARC 2012] }\end{array}$ & $\begin{array}{l}\text { OSHA PEL: } 5.0 \\
\text { NIOSH REL: Cancer } \\
\text { ACGIH TLV: } 10 \\
\text { (2 respirable fraction) }\end{array}$ \\
\hline Chromium & $\begin{array}{l}\text { The toxic effects of chromium } \\
\text { exposure, including lung and nasal } \\
\text { cancer, are primarily related to } \\
\text { hexavalent chromium } \\
\text { - Skin exposure to chromium dust } \\
\text { can cause skin irritation and skin } \\
\text { ulceration, and allergic contact } \\
\text { dermatitis }\end{array}$ & $\begin{array}{l}\text { Group 1: } \\
\text { carcinogenic } \\
\text { to humans } \\
\text { [IARC 2012] }\end{array}$ & $\begin{array}{l}\text { OSHA PEL: } 1,000 \\
\text { NIOSH REL: } 500 \\
\text { ACGIH TLV: } 500\end{array}$ \\
\hline Cobalt & $\begin{array}{l}\text { Exposure to elevated levels of } \\
\text { cobalt can cause gastrointestinal } \\
\text { irritation, nausea, and vomiting } \\
\text { - Inhaled cobalt can lead to lung } \\
\text { damage } \\
\text { - Skin exposure can cause irritant } \\
\text { and allergic contact dermatitis } \\
\text { [Vincoli 1997] }\end{array}$ & $\begin{array}{l}\text { Group 2B: } \\
\text { possibly } \\
\text { carcinogenic } \\
\text { to humans } \\
\text { [IARC 2006a] }\end{array}$ & $\begin{array}{l}\text { OSHA PEL: } 100 \\
\text { NIOSH REL: } 50 \\
\text { ACGIH TLV: } 20\end{array}$ \\
\hline Manganese & $\begin{array}{l}\text { Subclinical neurological effects, such } \\
\text { as decreased performance on } \\
\text { neurobehavioral tests; significantly } \\
\text { poorer eye-hand coordination, hand } \\
\text { steadiness, and reaction time; poorer } \\
\text { postural stability; and lower levels of } \\
\text { cognitive flexibility }\end{array}$ & None & $\begin{array}{l}\text { OSHA PEL: 5,000 } \\
\text { NIOSH REL: 1,000 } \\
\text { ACGIH TLV: } 100\end{array}$ \\
\hline Nickel & $\begin{array}{l}\text { Allergic contact dermatitis, } \\
\text { respiratory irritation, chronic } \\
\text { bronchitis, asthma, reduced lung } \\
\text { function }\end{array}$ & $\begin{array}{l}\text { Nickel } \\
\text { compounds, } \\
\text { Group 1: } \\
\text { carcinogenic to } \\
\text { humans; } \\
\text { paranasal } \\
\text { sinus, nasal } \\
\text { cavity, and lung }\end{array}$ & $\begin{array}{l}\text { OSHA PEL: 1,000 } \\
\text { NIOSH REL: } 15 \\
\text { ACGIH TLV: } 1,500\end{array}$ \\
\hline
\end{tabular}

IARC = International Agency for Research on Cancer 


\section{Indium}

Indium, including indium oxide, indium tin oxide and particularly indium nanoparticles, are widely used as a thin coating or conductive film on touch screens, flat panel displays such as liquid crystal display televisions, computer screens, solar panels, and aircraft and automobile windows [NTP 2009]. Occupational exposure to indium metals may cause eye, skin, and respiratory system irritation, liver, kidney, heart and blood effects, pulmonary edema and lung damage [NIOSH 2010; NTP 2009]. Presently, there is limited data available to characterize the potential health risks associated with occupational exposure to indium nanoparticles. The results of experimental in vivo and in vitro studies indicate that size of the particle is critical to subsequent biological effects, raising the possibility that indium nanoparticles may have the potential to be more hazardous than larger sized particles, and may exhibit mutagenic properties [Hasegawa et al. 2012; Lim et al. 2014].

The OELs for indium (including indium compounds) includes the NIOSH REL of 0.1 milligrams per cubic meter of air $\left(\mathrm{mg} / \mathrm{m}^{3}\right)$, as an 8-hour TWA [NIOSH 2010] and the ACGIH 8-hr TWA TLV of $0.1 \mathrm{mg} / \mathrm{m}^{3}$ [ACGIH 2018]. However, there is not a specific OEL for nanoscale indium particles.

\section{Flame Retardants}

Flame retardants are added to manufactured materials, surface finishes, and coatings to inhibit, suppress, or delay the production of flames and impede the spread of fire. In 1975, California Technical Bill 117 required that upholstered furniture filling, which is usually polyurethane foam, meet an open flame test. Manufacturers added chemical flame retardants to foam to meet this standard. While the standard only applied in California, manufacturers sold Technical Bill 117-compliant products across the North America to avoid having double inventory and to minimize liability. California updated the standard in 2014 (TB117-2013). While it does not ban flame retardants, flammability safety standards can now be met without them.

PBDEs were used in a variety of products from the 1980s until recently. All PBDEs have a common structure of brominated diphenyl ether molecules with 1-10 bromine atoms attached. PBDEs have 209 different structural variations possible [Lorber 2008]. The manufacturing and import of the PentaBDE and OctaBDE formulations were phased out in 2004 in the United States, and the production of DecaBDE ended in 2013. Manufacturers of flame retardants have introduced replacements for the PBDEs, but the toxicity of the replacements has not been well characterized [Allen et al. 2013]. These replacement compounds include novel brominated flame retardants like EH-TBB and BEH-TEBP, and phosphorus flame retardants like TDCIPP and TPHP.

PBDEs have a molecular structure similar to thyroid hormones [McDonald 2002]. Some human epidemiologic studies have shown an association between exposure to PBDEs and changes in male reproductive hormones, semen quality, thyroid homeostasis, and hormone levels and fertility in women; cryptorchidism (undescended testicles); low birth weight and length; delayed motor skills; and decreased IQ [Abdallah et al. 2015; Czerska et al. 2013; Dallaire et al. 2009; Dishaw et al. 2014; Grant et al. 2013]. 
TPHP, BEH-TEBP, EH-TBB and isopropylated triphenyl phosphate isomers are components of Firemaster 550, which appears to be the second most common flame retardant mixture currently applied to foam, after TDCIPP [Hoffman et al. 2014]. Studies indicate that BEHTEBP may affect thyroid hormones [Johnson et al. 2013]. TCEP and TCIPP are also used in some polyurethane foam. Some phosphorus flame retardants have been associated with decreased fertility, reduced sperm motility, altered reproductive and thyroid hormones, and cancer in humans [Dishaw et al. 2014; Meeker and Stapleton 2010; Meeker et al. 2013a,b; van der Veen and de Boer 2012].

Exposure to flame retardants in indoor environments like homes, schools, and offices is thought to be mainly from ingestion of dust, primarily during the transfer of the flame retardants from hands to mouth, with dermal absorption the next most important route of exposure [Abdallah et al. 2015]. In contrast, a recent study estimated that inhalation exposure exceeded intake from ingestion of some chlorinated organophosphate flame retardants [Schreder et al. 2016]. Experimental data using human skin equivalent tissue demonstrates that absorption through skin increased as the number of bromine atoms decreased for PBDEs [Abdallah et al. 2015]. Animal studies show that TDCIPP is easily absorbed through the skin and gastrointestinal tract [Nomeir et al. 1981], and recent studies of human ex vivo skin showed absorption of $28 \%$ for TCEP, 25\% for TCIPP, and 13\% for TDCIPP [Abdallah et al. 2016].

Only two of the flame retardants have OSHA PELs, TPHP and TCP. The OSHA PEL for TPHP is $3,000,000 \mathrm{ng} / \mathrm{m}^{3}\left(3 \mathrm{mg} / \mathrm{m}^{3}\right)$ while the PEL for tri-o-cresyl phosphate (one of the isomers of TCP) is $100,000 \mathrm{ng} / \mathrm{m}^{3}\left(0.1 \mathrm{mg} / \mathrm{m}^{3}\right)$. The NIOSH REL and ACGIH TLV for TPHP are also $3 \mathrm{mg} / \mathrm{m}^{3}$. The NIOSH REL and ACGIH TLV for tri-o-cresyl phosphate are also $0.1 \mathrm{mg} / \mathrm{m}^{3}$. In addition, ATSDR [2013] recommends that if dust levels of PentaBDE and OctaBDE exceed $5,000,000 \mathrm{ng} / \mathrm{m}^{3}\left(5 \mathrm{mg} / \mathrm{m}^{3}\right)$ then periodic air monitoring should be required. 


\section{References}

Abdallah MA, Pawar G, Harrad S [2015]. Effect of bromine substitution on human dermal absorption of polybrominated diphenyl ethers. Environ Sci Technol 49(18):10976-10983, http://dx.doi.org/10.1021/acs.est.5b03904.

Abdallah MA, Pawar G, Harrad S [2016]. Human dermal absorption of chlorinated organophosphate flame retardants; implications for human exposure. Toxicol Appl Pharmacol 291:28-37, http://dx.doi.org/10.1016/j.taap.2015.12.004.

ACGIH [2018]. 2018 TLVs ${ }^{\circledR}$ and BEIs ${ }^{\circledR}$ : threshold limit values for chemical substances and physical agents and biological exposure indices. Cincinnati, OH: American Conference of Governmental Industrial Hygienists.

ACOEM [2010]. ACOEM provides input to OSHA on key issues facing agency in 2010. Letter to David Michaels. Elk Grove Village, IL: American College of Occupational and Environmental Medicine, http://www.acoem.org/Page2Column.aspx?PageID=7392\&id=6676.

ACS [2011]. Lead. Atlanta, GA: American Cancer Society, http://www.cancer.org/cancer/cancercauses/othercarcinogens/athome/lead.

Alaee, M, Arias P, Sjodin A, Bergman A [2003]. An overview of commercially used brominated flame retardants, their applications, their use patterns in different countries/ regions and possible modes of release. Environ Int 29(6):683-689, http://dx.doi.org/10.1016/S0160-4120(03)00121-1.

Allen JG, McClean MD, Stapleton HM, Nelson JW, Webster TF [2007]. Personal exposure to polybrominated diphenyl ethers (PBDEs) in residential indoor air. Environ Sci Technol 41(13):4574-4579.

Allen JG, Stapleton HM, Vallarino J, McNeely E, McClean MD, Harrad SJ, Rauert CB, Spengler JD [2013]. Exposure to flame retardant chemicals on commercial airplanes. Env Health 12:17, http://dx.doi.org/10.1186/1476-069X-12-17.

ATSDR [2007]. Toxicological profile for lead. Atlanta, GA: U.S. Department of Health and Human Services.

ATSDR [2013]. Toxicological profile for polybrominated biphenyls and polybrominated diphenyl ethers. Atlanta, GA: U.S. Department of Health and Human Services, Agency for Toxic Substances and Disease Registry, http://www.atsdr.cdc.gov/toxprofiles/tp68.pdf.

Beaucham C, Ceballos D, Mueller C, Page E, La Guardia M [2018]. Field evaluation of sequential hand wipes for flame retardant exposure in an electronics recycling facility. Chemosphere 219:472-481, https://doi.org/10.1016/j.chemosphere.2018.12.027.

Bergman A, Rydén A, Law RJ, de Boer J, Covaci A, Alaee M, Birnbaum L, Petreas M, Rose M, Sakai S, Van den Eede N, van der Veen I [2012]. A novel abbreviation standard for organobromine, organochlorine and organophosphorus flame retardants and some characteristics of the chemicals. Environ Int 49C:57-82, http://dx.doi.org/10.1016/j.envint.2012.08.003. 
Billingsley KJ [2013]. Letter of September 30, 2013, from K. J. Billingsley, California Department of Public Health, to Juliann Sum, Division of Occupational Safety and Health (Cal/OSHA), California Department of Industrial Relations.

Brown-Williams H, Lichterman J, Kosnett M [2009]. Indecent exposure: lead puts workers and families at risk. Health Research in Action, University of California, Berkeley. Perspectives 4(1):1-9.

Canadian Centre for Occupational Health and Safety [2011]. Basic information on standing at work, http://www.ccohs.ca/oshanswers/ergonomics/standing/standing basic.html.

Carignan CC, Heiger-Bernays W, McClean MD, Roberts SC, Stapleton HM, Sjödin A, Webster TF [2013]. Flame retardant exposure among collegiate United States gymnasts. Environ Sci Technol 47(23):13848-13856, http://dx.doi.org/10.1021/es4037868.

Carignan CC, Fang M, Stapleton HM, Heiger-Bernays W, McClean MD, Webster TF [2016]. Urinary biomarkers of flame retardant exposure among collegiate U.S. gymnasts. Environ Int 94:362-368, https://dx.doi.org/10.1016\%2Fj.envint.2016.06.030.

Carlsson H, Nilsson U, Becker G, Östman C [1997]. Organophosphate ester flame retardants and plasticizers in the indoor environment: analytical methodology and occurrence. Environ Sci Technol 31(10):2931-2936, https://dx.doi.org/10.1021/es970123s.

CDC (Centers for Disease Control and Prevention) [2009]. Childhood lead poisoning associated with lead dust contamination of family vehicles and child safety seats --- Maine, 2008. MMWR 58(32):890-893.

CDC (Centers for Disease Control and Prevention) [2012]. Adult blood lead epidemiology and surveillance (ABLES), http://www.cdc.gov/niosh/topics/ABLES/description.html.

CDC (Centers for Disease Control and Prevention) [2013a]. Blood lead levels in children aged 1-5 years — United States, 1999-2010. MMWR 62(13):245-248.

CDC (Centers for Disease Control and Prevention) [2013b]. Very high blood lead levels among adults — United States, 2002-2011. MMWR 62(47):967-971.

CDC (Centers for Disease Control and Prevention) [2015a]. Adult blood lead epidemiology and surveillance (ABLES), http://www.cdc.gov/niosh/topics/ables/description.html.

CDC (Centers for Disease Control and Prevention) [2015b]. Fourth national report on human exposure to environmental chemicals updated tables, February, 2015, http://www.cdc.gov/biomonitoring/pdf/FourthReport_UpdatedTables_Feb2015.pdf.

CDC (Centers for Disease Control and Prevention) [2018]. National report on human exposure to environmental chemicals updated tables, March 2018, https://www.cdc.gov/exposurereport/.

CDPH [2009]. Medical guidelines for the lead-exposed worker. Sacramento, CA: California Department of Public Health, Occupational Lead Poisoning Prevention Program, http://www.cdph.ca.gov/programs/olppp/Documents/medgdln.pdf. 
CDPH [2014]. Management guidelines for blood lead levels in adults. Sacramento, CA: California Department of Public Health, Occupational Lead Poisoning Prevention Program, http://www.cdph.ca.gov/programs/olppp/documents/adultmgtguide.pdf.

Ceballos D, Dong Z [2016]. The formal electronic recycling industry: challenges and opportunities in occupational and environmental health research. Environ Int 95:157-166, https://doi.org/10.1016/j.envint.2016.07.010.

Ceballos D, Beaucham C, Page E [2016]. Metal exposures at three U.S. electronic scrap recycling facilities. J Occup Environ Med 14(6):401-408, http://dx.doi.org/10.1080/15459624.2016.1269179.

CFR. Code of Federal Regulations. Washington, DC: U.S. Government Printing Office, Office of the Federal Register.

Chan PC, Ho KH, KanKK, Stuhmiller JH, Mayorga MA [2001]. Evaluation of impulse noise criteria using human volunteer data. J Acoust Soc Amer 110(4):1967-1975.

Cooper EM, Covaci A, vanNuijs AL, Webster TF, Stapleton HM [2011]. Analysis of the flame retardant metabolites bis(1,3-dichloro-2-propyl) phosphate (BDCPP) and diphenyl phosphate (DPP) in urine using liquid chromatography-tandem mass spectrometry. Anal Bioanal Chem 401(7):2123-2132, http://dx.doi.org/10.1007/s00216-011-5294-7.

CSTE [2009]. Council of State and Territorial Epidemiologist. Proposal to adopt new or amended surveillance definitions for four environmental conditions. CSTE position statement 09-OH-02. Atlanta, GA: Council of State and Territorial Epidemiologists, http://c.ymcdn.com/sites/www.cste.org/resource/resmgr/PS/09-OH-02.pdf.

CSTE [2015]. Public health reporting and national notification for elevated blood lead levels. CSTE position statement 15-eH-01. Atlanta, GA: Council of State and Territorial Epidemiologists, http://c.ymcdn.com/sites/www.cste.org/resource/resmgr/2015PS/2015PSFinal/15-EH-01.pdf.

Czerska M, Zieliński M, Kamińska J, Ligocka D [2013]. Effects of polybrominated diphenyl ethers on thyroid hormone, neurodevelopment and fertility in rodents and humans. Int $\mathrm{J}$ Occup Med Environ Health 26(4):498-510, http://dx.doi.org/10.2478/s13382-013-0138-7.

Dallaire R, Dewailly É, Pereg D, Dery S, Ayotte P [2009]. Thyroid function and plasma concentrations of polyhalogenated compounds in Inuit adults. Environ Health Perspect 117:1380-1386, https://dx.doi.org/10.1289/ehp.0900633.

Dishaw LV, Macaulay LJ, Roberts SC, Stapleton HM [2014]. Exposures, mechanisms, and impacts of endocrine-active flame retardants. Curr Opin Pharmacol 19:125-133, http://dx.doi.org/10.1016/j.coph.2014.09.018.

Dodson RE, Van den Eede, Covaci A, Petrovich LJ, Brody JG, Rudel RA [2014]. Urinary biomarkers of phosphate flame retardants: levels in California adults and recommendations for future studies. Environ Sci Technol 48(23):13625-13633, http://dx.doi.org/10.1021/es503445c. 
EPA [1998]. Risk analysis to support standards for lead in paint, dust, and soil. EPA Publication EPA-747-R097-006. Washington, D.C.: U.S. Environmental Protection Agency, http://www2.epa.gov/lead/risk-analysis-support-standards-lead-paint-dust-and-soil-volume-ichapters-1-7-and-appendix-epa.

Esswein EJ, Boeniger MF, Ashley K [2011]. Handwipe method for removing lead from skin. J ASTM International 8(5):1-10, https://doi.org/10.1520/JAI103527.

Filon FL, Boeniger M, Maina G, Adami G, Spinelli P, Damian A [2006]. Skin absorption of inorganic lead $(\mathrm{PbO})$ and the effect of skin cleansers. J Occup Environ Med 48(7):692-699, http://dx.doi.org/10.1097/01.jom.0000214474.61563.1c.

Grant K, Goldizen FC, Sly PD, Brune MN, Neira M, van den Berg M, Norman RE [2013]. Health consequences of exposure to e-scrap: a systematic review. Lancet Glob Health 1(6):e350-e361, http://dx.doi.org/10.1016/S2214-109X(13)70101-3.

Hammel SC, Hoffman K, Webster TF, Anderson KA, Stapleton HM [2016]. Measuring personal exposure to organophosphate flame retardants using silicone wristbands and hand wipes. Environ Sci Technol 50(8):4483-4491, http://dx.doi.org/10.1021/acs.est.6b00030.

Hasegawa G, Shimonaka M, Ishihara Y [2012]. Differential genotoxicity of chemical properties and particle size of rare metal and metal oxide nanoparticles. J Appl Toxicol 32(1):72-80, http://dx.doi.org/10.1002/jat.1719.

Hoffman K, Fang M, Horman B, Patisaul HB, Garantziotis S, Birnbaum LS, Stapleton HM [2014]. Urinary tetrabromobenzoic acid (TBBA) as a biomarker of exposure to the flame retardant mixture Firemaster ${ }^{\circledR}$ 550. Environ Health Perspect 122(9):963-969, http://dx.doi.org/10.1289/ehp.1308028.

Hoffman K, Garantziotis S, Birnbaum LS, Stapleton HM [2015]. Monitoring indoor exposure to organophosphate flame retardants: hand wipes and house dust. Environ Health Perspect 123(2):160-165, http://dx.doi.org/10.1289/ehp.1408669.

Holland MG, Cawthorn D [2016]. ACOEM position statement: workplace lead exposure. JOEM 58(12):371-373, https://dx.doi.org/10.1097/JOM.0000000000000928.

Hornung RW, Reed LD [1990]. Estimation of average concentration in the presence of nondetectable values. Appl Occup Environ Hyg 5(1):46-51, http://dx.doi.org/10.1080/1047322x.1990.10389587.

HUD [2012]. Guidelines for the evaluation and control of lead-based paint hazards in housing, http://portal.hud.gov/hudportal/HUD?src=/program_offices/healthy_homes/lbp/hudguidelines.

IARC [2006a]. IARC monographs on the evaluation of carcinogenic risks to humans: cobalt in hard metals and cobalt sulfate, gallium arsenide, indium phosphide and vanadium pentoxide. Volume 86. Lyon, France: World Health Organization, International Agency for Research on Cancer, https://monographs.iarc.fr/ENG/Monographs/vol86/index.php. 
IARC [2006b]. IARC monographs on the evaluation of carcinogenic risks to humans: inorganic and organic lead compounds. Volume 87. Lyon, France: World Health Organization, International Agency for Research on Cancer, https://monographs.iarc.fr/ENG/Monographs/vol87/index.php.

IARC [2012]. IARC monographs on the evaluation of carcinogenic risks to humans: arsenic, metals, fibres and dusts. Volume 100C. Lyon, France: World Health Organization, International Agency for Research on Cancer, https://monographs.iarc.fr/ENG/Monographs/vol100C/index.php.

Institute of Medicine [2012]. Potential health risks from recurrent lead exposure of DOD firing range personnel. Washington, D.C.: National Academies Press.

Jakobsson K, Thuresson K, Rylander L, Sjödin A, Hagmar L, Bergman A [2002]. Exposure to polybrominated diphenyl ethers and tetrabromobisphenol A among computer technicians. Chemosphere 46(5):709-716, https://doi.org/10.1016/S0045-6535(01)00235-1.

Jayatilaka NK, Restrepo P, Williams L, Ospina M, Valentin-Blasini L, Calafat AM [2017]. Quantification of three chlorinated dialkyl phosphates, diphenyl phosphate, 2,3,4,5-tetrabromobenzoic acid, and four other organophosphates in human urine by solid phase extraction-high performance liquid chromatography-tandem mass spectrometry. Anal Bioanal Chem 409(5):1323-1332, http://dx.doi.org/10.1007/s00216-016-0061-4.

Johnson PI, Stapleton HM, Mukherjee B, Hauser R, Meeker JD [2013]. Associations between brominated flame retardants in house dust and hormone levels in men. Sci Total Environ 445-446:177-184, http://dx.doi.org/10.1016/j.scitotenv.2012.12.017.

Kosarac I, Kubwabo C, Foster W [2016]. Quantitative determination of nine urinary metabolites of organophosphate flame retardants using solid phase extraction and ultra performance liquid chromatography coupled to tandem mass spectrometry (UPLC-MS/MS). J Chromatogr B 1014:24-30, http://dx.doi.org/10.1016/j.jchromb.2016.01.035.

Kosnett MJ, Wedeen RP, Rothenberg SJ, Hipkins KL, Materna BL, Schwartz BS, Hu H, Woolf A [2007]. Recommendations for medical management of adult blood lead exposure. Environ Health Perspect 115(3):463-471, http://dx.doi.org/10.1289/ehp.9784.

Kurebayashi H, Tanaka A, Yamaha T [1985]. Metabolism and disposition of the flame-retardant plasticizer, tri-para-cresyl phosphate, in the rat. Toxicol Appl Pharmacol 77(3):395-404.

La Guardia MJ, Hale RC, Harvey E [2006]. Detailed polybrominated diphenyl ether (PBDE) congener composition of the widely used Penta-, Octa-, and Deca-PBDE technical flame-retardant mixtures. Environ Sci Technol 40(2):6247-6254, http://dx.doi.org/10.1021/es060630m.

La Guardia MJ, Hale RC [2015]. Halogenated flame-retardant concentrations in settled dust, respirable and inhalable particulates and polyurethane foam at gymnastic training facilities and residences. Environ Int 79:106-114, http://dx.doi.org/10.1016/j.envint.2015.02.014.

Lauwerys RR, Hoet P [2001]. Industrial chemical exposure: guidelines for biological monitoring. 3rd ed. Boca Raton, FL: CRC Press, LLC, pp. 21-180. 
Lim CH, Han JH, Cho HW, Kang M [2014]. Studies on the toxicity and distribution of indium compounds according to particle size in sprague-dawley rats. Toxicol Res 30(1):55-63.

Lorber M [2008]. Exposure of Americans to polybrominated diphenyl ethers. J Expo Sci Environ Epidemiol 18(1):2-19, http://dx.doi.org/10.1038/sj.jes.7500572.

Mäkinen MS, Mäkinen MR, Koistinen JT, Pasanen AL, Pasanen PO, Kalliokoski PJ, Korpi AM [2009]. Respiratory and dermal exposure to organophosphorus flame retardants and tetrabromobisphenol A at five work environments. Environ Sci Technol 43(3):941-947, http://dx.doi.org/10.1021/es802593t.

McDonald TA [2002]. A perspective on the potential health risks of PBDEs. Chemosphere 46(5):745-755, http://dx.doi.org/10.1016/S0045-6535(01)00239-9.

Meeker JD, Stapleton HM [2010]. House dust concentrations of organophosphate flame retardants in relation to hormone levels and semen quality parameters. Environ Health Perspect 118(3):318-323, http://dx.doi.org/10.1289/ehp.0901332.

Meeker JD, Cooper EM, Stapleton HM, Hauser R [2013a]. Exploratory analysis of urinary metabolites of phosphorus-containing flame retardants in relation to markers of male reproductive health. Endocr Disruptors (Austin) 1(1):e26306, http://dx.doi.org/10.4161/endo.26306.

Meeker JD, Cooper EM, Stapleton HM, Hauser R [2013b]. Urinary metabolites of organophosphate flame retardants: temporal variability and correlations with house dust concentrations. Environ Health Perspect 121(5):580-585, http://dx.doi.org/10.1289/ehp.1205907.

Moline JM, Landrigan PJ [2005]. Lead. In: Rosenstock L, Cullen MR, Brodkin CA, Redlich CA, eds. Textbook of clinical occupational and environmental medicine. 2nd ed. Philadelphia, PA: Elsevier Saunders, pp. 967-979.

National Toxicology Program (NTP) [2009]. Chemical information profile for indium tin oxide. Research Triangle Park, NC: National Toxicology Program, National Institute of Environmental Health Sciences, National Institutes of Health, U.S. Department of Health and Human Services, https://ntp.niehs.nih.gov/ntp/noms/support docs/ito060309 508.pdf.

National Toxicology Program (NTP) [2011]. Report on carcinogens, Twelfth Edition. Research Triangle Park, NC: U.S. Department of Health and Human Services, National Institutes of Health, National Institute of Environmental Health Sciences, National Toxicology Program, http://ntp.niehs.nih.gov/ntp/roc/twelfth/profiles/Lead.pdf.

National Toxicology Program (NTP) [2012]. Monograph on the health effects of lowlevel lead. Research Triangle Park, NC: U.S. Department of Health and Human Services, National Institutes of Health, National Institute of Environmental Health Sciences, National Toxicology Program, https://ntp.niehs.nih.gov/ntp/ohat/lead/final/monographhealtheffectslowlevellead newissn 508.pdf. 
Newman N, Jones C, Page E, Ceballos D, Oza A [2015]. Investigation of childhood lead poisoning from parenteral take-home exposure from an electronic scrap recycling facility - Ohio, 2012. MMWR 64(27):743-745, https://www.cdc.gov/mmwr/preview/mmwrhtml/mm6427a3.htm.

NIOSH [1995]. Report to Congress on the workers' home contamination study conducted under the Workers' Family Protection Act 29 U.S.C. 671a. Cincinnati, OH: U.S. Department of Health and Human Services, Centers for Disease Control and Prevention, National Institute for Occupational Safety and Health, DHHS (NIOSH) Publication No. 95-123, http://www.cdc.gov/niosh/docs/95-123/.

NIOSH [1997]. Musculoskeletal disorders and workplace factors: a critical review of epidemiologic evidence for work-related musculoskeletal disorders of the neck, upper extremity, and low back. Cincinnati, OH: U.S. Department of Health and Human Services, Centers for Disease Control and Prevention, National Institute for Occupational Safety and Health, (DHHS) Publication No. 97-141, http:/www.cdc.gov/niosh/docs/97-141/.

NIOSH [2005]. Immigration and Naturalization Services. National Firearms Unit, Altoona, PA. By Harney J, King B, Tubbs R, Crouch K, Hayden C, Kardous C, Khan A, Mickelson L, Wilson R. Cincinnati, OH: U.S. Department of Health and Human Services, Centers for Disease Control and Prevention, National Institute for Occupational Safety and Health, Health Hazard Evaluation Report 2000-0191-2960, https://www.cdc.gov/niosh/hhe/reports/pdfs/2000-0191-2960.pdf.

NIOSH [2009]. Exposure to hazardous metals during electronics recycling at four UNICOR facilities. By Page E, Sylvain D. Cincinnati, OH: U.S. Department of Health and Human Services, Centers for Disease Control and Prevention, National Institute for Occupational Safety and Health, Health Hazard Evaluation Report 2008-0055-3098, https://www.cdc.gov/niosh/hhe/reports/pdfs/2008-0055-3098.pdf.

NIOSH [2010]. NIOSH pocket guide to chemical hazards. Cincinnati, OH: U.S. Department of Health and Human Services, Centers for Disease Control and Prevention, National Institute for Occupational Safety and Health, DHHS (NIOSH) Publication No. 2010-168c, http://www.cdc.gov/niosh/npg/.

NIOSH [2014a]. Evaluation of occupational exposures at an electronic scrap recycling facility. By Ceballos D, Chen L, Page E, Echt A, Oza A, Ramsey J. Cincinnati, OH: U.S. Department of Health and Human Services, Centers for Disease Control and Prevention, National Institute for Occupational Safety and Health, Health Hazard Evaluation Report 2012-0100-3217, https://www.cdc.gov/niosh/hhe/reports/pdfs/2012-0100-3217.pdf.

NIOSH [2014b]. Current strategies for engineering controls in nanomaterial production and downstream handling processes. Cincinnati, OH: U.S. Department of Health and Human Services, Centers for Disease Control and Prevention, National Institute for Occupational Safety and Health, DHHS (NIOSH) Publication No. 2014-102, http://www.cdc.gov/niosh/docs/2014-102/pdfs/2014-102.pdf. 
NIOSH [2014c]. Indoor firing ranges. Cincinnati, OH: U.S. Department of Health and Human Services, Centers for Disease Control and Prevention, National Institute for Occupational Safety and Health, http://www.cdc.gov/niosh/topics/ranges/.

NIOSH [2016]. NIOSH manual of analytical methods. Consideration of sampler wall deposits. Inclusion of material adhering to internal cassette surfaces during sampling and analysis of airborne particles. Cincinnati, OH: U.S. Department of Health and Human Services, Centers for Disease Control and Prevention, National Institute for Occupational Safety and Health, https://www.cdc.gov/niosh/docs/2003-154/cassetteguidance.html.

NIOSH [2018a]. Evaluation of exposure to metals, flame retardants, and nanomaterials at an electronics recycling company. By Beaucham CC, Ceballos D, Page EH, Mueller C, Calafat A, Sjodin A, Ospina M, La Guardia M, Glassford E. Cincinnati, OH: U.S. Department of Health and Human Services, Centers for Disease Control and Prevention, National Institute for Occupational Safety and Health, Health Hazard Evaluation Report 2015-0050-3308, https://www.cdc.gov/niosh/hhe/reports/pdfs/2015-0050-3308.pdf.

NIOSH [2018b]. Evaluation of exposure to metals at an electronics recycling facility. By Grimes GR, Beaucham CC, Ramsey JG. Cincinnati, OH: U.S. Department of Health and Human Services, Centers for Disease Control and Prevention, National Institute for Occupational Safety and Health, Health Hazard Evaluation Report 2016-0242-3315, https://www.cdc.gov/niosh/hhe/reports/pdfs/2016-0242-3315.pdf.

NIOSH [2018c]. NIOSH manual of analytical methods (NMAM). 5th ed. O'Connor PF, Ashley K, eds. Cincinnati, OH: U.S. Department of Health and Human Services, Centers for Disease Control and Prevention, National Institute for Occupational Safety and Health, DHHS (NIOSH) Publication No. 2014-151, http://www.cdc.gov/niosh/nmam.

Nomeir AA, Kato S, Matthews HB [1981]. The metabolism and disposition of tris(1,3dichloro-2-propyl)phosphate (Fyrol FR-2) in the rat. Toxicol Appl Pharmacol 57(3):401-413, https://doi.org/10.1016/0041-008X(81)90238-6.

OSHA [2003]. Standard interpretation letter-lead standard 29 CFR 1926.62 (i)(2)(ii), http://www.osha.gov/pls/oshaweb/owadisp.show document?p table=INTERPRETATIONS\&p $\underline{\mathrm{id}=25617 .}$.

Ospina M, Jayatilaka N, Wong L, Restrepo P, Calafat A [2018]. Exposure to organophosphate flame retardant chemicals in the U.S. general population: data from the 2013-2014 National Health and Nutrition Examination Survey. Environ Int 110(2018):32-41, http://dx.doi.org/10.1016/j.envint.2017.10.001.

Patterson J, Hamernik R [1992]. An experimental basis for the estimation of auditory system following exposures to impulse noise. In: Noise-induced hearing loss. Dancer A, Henderson D, Salvi R, Hamernik R, eds. Philadelphia, PA: BC Decker, pp. 336-348.

Pekkarinen J, Iki M, Starck J, Pyykko I [1993]. Hearing loss risk from exposure to shooting impulses in workers exposed to occupational noise. Br J Aud 27(3):175-182. 
Petropoulou SS, Petreas M, Park JS [2016]. Analytical methodology using ion-pair liquid chromatography-tandem mass spectrometry for the determination of four di-ester metabolites of organophosphate flame retardants in California human urine. J Chromatogr A 1434:70-80, http://dx.doi.org/10.1016/j.chroma.2016.01.020.

Pettersson-Julander A, van Bavel B, Engwall M, Westberg H [2004]. Personal air sampling and analysis of polybrominated diphenyl ethers and other bromine containing compounds at an electronic recycling facility in Sweden. J Environ Monit 6(11):874-80, http://dx.doi.org/10.1039/B408381D.

Preston EV, McClean MD, Claus Henn B, Stapleton HM, Braverman LE, Pearce EN, Makey CM, Webster TF [2017]. Associations between urinary diphenyl phosphate and thyroid function. Environ Int 101:158-164, http://dx.doi.ord/10.1016/j.envint.2017.01.020.

Proctor NH, Hughes JP, Fischmann ML [1991]. Chemical hazards of the worplace, 3rd ed. New York: Van Nostrand Reinhold.

Rosenberg C, Hämeilä M, Tornaeus J, Säkkinen K, Puttonen K, Korpi A, Kiilunen M, Linnainmaa M, Hesso A [2011]. Exposure to flame retardants in electronics recycling sites. Ann Occup Hyg 55(6):658-665, http://dx.doi.org/10.1093/annhyg/mer033.

Schreder ED, Uding N, La Guardia MJ [2016]. Inhalation a significant exposure route for chlorinated organophosphate flame retardants. Chemosphere 150:499-504, http://dx.doi.org/10.1016/j.chemosphere.2015.11.084.

Schubauer-Berigan MK, Deddens JA, Couch JR, Petersen MR [2010]. Risk of lung cancer associated with quantitative beryllium exposure metrics within an occupational cohort. Occup Environ Med 68(5):354-360, http://dx.doi.org/10.1136/oem.2010.056515.

Schwartz BS, Hu H [2007]. Adult lead exposure: time for change. Environ Health Perspect 115(3):451-454, http://dx.doi.org/10.1289/ehp.9782.

Schwartz BS, Stewart WF [2007]. Lead and cognitive function in adults: a question and answers approach to a review of the evidence for cause, treatment, and prevention. Int Rev Psychiatry 19(6):671-692, http://dx.doi.org/10.1080/09540260701797936.

Sjödin A, Hagmar L, Klasson-Wehler E, Kronholm-Diab K, Jakobsson E, Bergman A [1999]. Flame retardant exposure: polybrominated diphenyl ethers in blood from Swedish workers. Environ Health Perspect 107(8):643-648, http://dx.doi.org/10.1289/ehp.99107643.

Sjödin A, Carlsson H, Thuresson K, Sjolin S, Bergman A, Ostman C [2001]. Flame retardants in indoor air at an electronics recycling plant and at other work environments. Environ Sci Technol 35(3):448-454, http://dx.doi.org/10.1021/es000077n.

Sjödin A, Wong LY, Jones RS, Park A, Zhang Y, Hodge C, Dipietro E, McClure C, Turner W, Needham LL, Patterson Jr DG [2008]. Serum concentrations of polybrominated diphenyl ethers (PBDEs) and polybrominated biphenyl (PBB) in the United States population: 20032004. Environ Sci Technol 42(4):1377-1384, http://dx.doi.org/10.1021/es702451p. 
Stapleton HM, Dodder NG [2008]. Photodegradation of decabromodiphenyl ether in house dust by natural sunlight. Environ Toxicol Chem 27(2)306-312, http://dx.doi.org/10.1897/07-301R.1.

Stapleton HM, Klosterhaus S, Keller A, Ferguson PL, van Bergen S, Cooper E, Webster T, Blum A [2011]. Identification of flame retardants in polyurethane foam collected from baby products. Environ Sci Technol 45(12):5323-5331, http://dx.doi.org/10.1021/es2007462.

Stapleton HM, Misenheimer J, Hoffman K, Webster TF [2014]. Flame retardant associations between children's handwipes and house dust. Chemosphere 116:54-60, http://dx.doi.org/10.1016/j.chemosphere.2013.12.100.

Stauber JL, Florence TM, Gulson B, Dale L [1994]. Percutaneous absorption of inorganic lead compounds. Sci Total Environ 145(1-2):55-70, https://doi.org/10.1016/0048-9697(94)90297-6.

Sun CC, Wong TT, Hwang YH, Chao KY, Jee SH, Wang JD [2002]. Percutaneous absorption of inorganic lead compounds. Am Ind Hyg Assoc J 63(5):641-646, https://doi.org/10.1080/15428110208984751.

Thuresson K, Hoglund P, Hagmar L, Sjodin A, Bergman A, Jakobsson K [2006a]. Apparent half-lives of hepta- to decabrominated diphenyl ethers in human serum as determined in occupationally exposed workers. Environ Health Perspect 114(2):176-181, https://dx.doi.org/10.1289/ehp.8350.

Thuresson K, Bergman K, Rothenbacher K, Herrmann T, Sjölin S, Hagmar L, Päpke O, Jakobsson K [2006b]. Polybrominated diphenyl ether exposure to electronics recycling workers--a follow up study. Chemosphere 64(11):1855-1861, https://doi.org/10.1016/j.chemosphere.2006.01.055.

van der Veen I, de Boer J [2012]. Phosphorus flame retardants: properties, production, environmental occurrence, toxicity and analysis. Chemosphere 88(10):1119-1153, http://dx.doi.org/10.1016/j.chemosphere.2012.03.067.

Vincoli JW [1997]. Risk management for hazardous chemicals. Boca Raton, FL: CRC Press.

Watkins DJ, McClean MD, Fraser AJ, Weinberg J, Stapleton HM, Sjödin A, Webster TF [2011]. Exposure to PBDEs in the office environment: evaluating the relationships between dust, handwipes, and serum. Environ Health Perspect 19(9):1247-1252, http://dx.doi.org/10.1289/ehp.1003271.

Watkins DJ, McClean MD, Fraser AJ, Weinberg J, Stapleton HM, Webster TF [2013]. Associations between PBDEs in office air, dust, and surface wipes. Environ Int 59:124-132, http://dx.doi.org/10.1016/j.envint.2013.06.001.

WHO [1992]. Environmental health criteria 134. Cadmium. Geneva, Switzerland: World Health Organization, http://www.inchem.org/documents/ehc/ehc/ehc134.htm. 
Keywords: North American Industry Classification System (NAICS) 423930 (Recyclable Material Merchant Wholesalers), Wisconsin, Electronics Recycling, E-scrap, E-waste, Flame Retardants, Lead, Cadmium, Indium, Lithium 
The Health Hazard Evaluation Program investigates possible health hazards in the workplace under the authority of the Occupational Safety and Health Act of 1970 (29 U.S.C. § 669(a) (6)). The Health Hazard Evaluation Program also provides, upon request, technical assistance to federal, state, and local agencies to investigate occupational health hazards and to prevent occupational disease or injury. Regulations guiding the Program can be found in Title 42, Code of Federal Regulations, Part 85; Requests for Health Hazard Evaluations (42 CFR Part 85).

\section{Disclaimer}

The recommendations in this report are made on the basis of the findings at the workplace evaluated and may not be applicable to other workplaces.

Mention of any company or product in this report does not constitute endorsement by NIOSH.

Citations to Web sites external to NIOSH do not constitute NIOSH endorsement of the sponsoring organizations or their programs or products. NIOSH is not responsible for the content of these Web sites. All Web addresses referenced in this document were accessible as of the publication date.

\section{Acknowledgments}

Analytical Support: Maxxam Analytics, Mark La Guardia (College of William and Mary) Desktop Publisher: Shawna Watts

Industrial Hygiene Field Assistance: Donnie Booher, Kendra Broadwater

Logistics: Kevin Moore

Medical Field Assistance: Deborah Sammons, Barbara Mackenzie, Shirley Robertson, Shilpa Gouda, Elena Page

Biomonitoring Data: Antonia Calafat, Andreas Sjodin, Maria Ospina, Nayana Jayatilaka, Richard Jones

\section{Availability of Report}

Copies of this report have been sent to the employer and employees at the facility. The state and local health department and the Occupational Safety and Health Administration Regional Office have also received a copy. This report is not copyrighted and may be freely reproduced.

\section{Recommended citation for this report:}

NIOSH [2019]. Evaluation of exposure to metals and flame retardants at an electronics recycling company. By Grimes GR, Beaucham CC, Grant MP, Ramsey JG. Cincinnati, OH: U.S. Department of Health and Human Services, Centers for Disease Control and Prevention, National Institute for Occupational Safety and Health, Health Hazard Evaluation Report 2016-0257-3333, https:/www.cdc.gov/niosh/hhe/reports/pdfs/20160257-3333.pdf. 
Delivering on the Nation's promise:

Promoting productive workplaces through safety and health research

To receive NIOSH documents or more information about occupational safety and health topics, please contact NIOSH:

Telephone: 1-800-CDC-INFO (1-800-232-4636)

TTY: 1-888-232-6348

CDC INFO: www.cdc.gov/info

or visit the NIOSH Web site at www.cdc.gov/niosh

For a monthly update on news at $\mathrm{NIOSH}$, subscribe to

$\mathrm{NIOSH}$ eNews by visiting www.cdc.gov/niosh/eNews. 